\title{
Discovery of a novel class of D-amino acid oxidase (DAO) inhibitors with the Schrödinger computational platform
}

Haifeng Tang ${ }^{*, 1}$, Kristian Jensen ${ }^{1}$, Evelyne M. Houang ${ }^{1}$, Fiona M. McRobb ${ }^{1}$, Sathesh Bhat ${ }^{1}$, Mats Svensson ${ }^{1}$, Art Bochevarov, ${ }^{1}$ Tyler Day ${ }^{1}$, Markus K. Dahlgren ${ }^{1}$, Jeff Bell ${ }^{1}$, Leah Frye ${ }^{1}$, Robert Skene ${ }^{2}$, James H. Lewis ${ }^{3}$, James D. Osborne $^{3}$, Jason P. Tierney ${ }^{3}$, James A. Gordon ${ }^{3}$, Maria A. Palomero-Vazquez ${ }^{3}$, Caroline Gallati ${ }^{3}$, Robert S. L. Chapman $^{3}$, Daniel R. Jones ${ }^{3}$, Kim L. Hirst ${ }^{3}$, Mark Sephton ${ }^{3}$, Alka Chauhan ${ }^{3}$, Andrew Sharpe ${ }^{3}$, Piero Tardia ${ }^{3}$, Elsa A Dechaux $^{4}$, Andrea Taylor ${ }^{4}$, Ross D Waddell ${ }^{4}$, Andrea Valentine ${ }^{4}$, Holden B. Janssens ${ }^{5}$, Omar Aziz ${ }^{4}$, Dawn E. Bloomfield ${ }^{3}$, Sandeep Ladha ${ }^{3}$, Ian J. Frazer ${ }^{3}$, John M. Ellard ${ }^{3,4}$

1. Schrödinger Inc.

2. Takeda Development Center Americas, Inc.

3. Charles River Laboratories, Chesterford Research Park, CB10 1XL, United Kingdom

4. Charles River Laboratories, 8-9 Spire Green Centre, Harlow, Essex, CM19 5TR, United Kingdom

5. Charles River Laboratories, South San Francisco, CA, USA

\section{INTRODUCTION}

D-serine is a physiological co-agonist of the N-methyl D-aspartate (NMDA) type of glutamate receptor, a key excitatory neurotransmitter receptor in the brain. D-Serine in the brain is synthesized from its L-isomer by serine racemase and is metabolized by the D-amino acid oxidase (DAO, DAAO), a flavoenzyme that catalyzes the oxidative degradation of D-amino acids including D-serine to the corresponding $\alpha$-keto acids. The function of the NMDA receptor requires the presence of both the agonist (glutamate) and the co-agonist (D-serine, glycine, and/or D-alanine). Importantly, D-serine has been reported to be the predominant NMDA co-agonist in the forebrain and linked directly to schizophrenia. ${ }^{1} \mathrm{D}$-serine concentrations in serum and cerebrospinal fluid have been reported to be decreased in schizophrenia patients, ${ }^{2}$ and oral administration of D-serine improved symptoms of schizophrenia when used as an adjuvant to typical and atypical antipsychotics. ${ }^{3}$ Thus, it is plausible to explore pharmaceutical inhibition of DAO function as putative novel therapeutics to treat the positive (psychotic), negative and cognitive symptoms in schizophrenia.

The simplest DAO inhibitor benzoic acid (1) was reported in $1956 .{ }^{4}$ Since the early 2000s, many small molecule DAO inhibitors have been reported in the literature (Figure 1). ${ }^{5}$ They all mimic the substrate D-serine and bind to the catalytic site of DAO. The early inhibitors $(\mathbf{1 - 6})^{6}$ can all be characterized as aryl carboxylic acids or corresponding acid-bioisosteres with low molecular weight. Although they are potent and highly ligand efficient, they lack the vectors that are needed for optimization of potency and physicochemical properties. To that end in 2013, Astellas reported a new class of DAO inhibitors (7) which contain a tail group reaching into a hydrophobic pocket perpendicular to the head group. ${ }^{7}$ Takeda also worked on a similar chemical series which culminated in the discovery of their clinical candidate TAK-831 (8). The kojic acid derivatives (9) were also explored by a Johns Hopkins research group. ${ }^{8}$ In addition, Sunovion reported a new class of DAO inhibitors (10) that stabilize an activesite lid-open conformation, although the lead compounds suffer from poor pharmacokinetic and brain penetration properties. $^{9}$ 
<smiles>O=C(O)c1ccccc1</smiles>

1

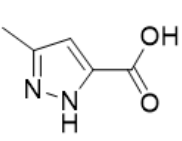

2

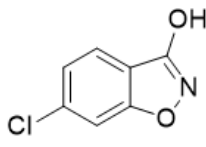

3

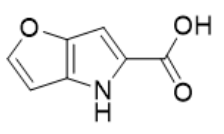

4 (SEP-227900)

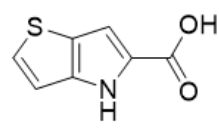

5

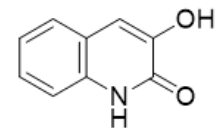

6

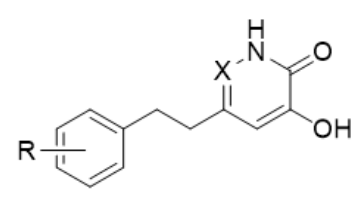

$7(X=C$ or $N)$

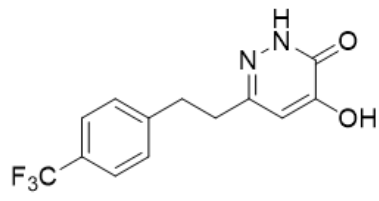

8 (TAK-831)<smiles>O=c1cc(CSc2ccc(Cl)c(Cl)c2)occ1O</smiles>

9<smiles>O=C(O)CCc1cc2c(-c3ccccc3)cc(=O)oc2cc1O</smiles>

Figure 1. Previously reported inhibitors of DAO

A few DAO inhibitors have entered into clinical development. Currently, only SyneuRx is actively developing $\mathrm{NaBen}{ }^{\circledR}$ (sodium salt of $\mathbf{1}$ ) in a phase II/III clinical trial for refractory schizophrenia in adults. ${ }^{10}$ Sepracor was developing SEP-227900 for neuropathic pain around 2010. Takeda was developing TAK-831 (luvadaxistat, 8) in phase 2 clinical trials ${ }^{11}$ for the treatment of schizophrenia, which was the subject of a license agreement with Neurocrine in 2020. ${ }^{12}$ In March 2021, Neurocrine reported topline data from the Phase II INTERACT study in adults with negative symptoms of schizophrenia treated with luvadaxistat (NBI-1065844/TAK-831). Although luvadaxistat did not meet its primary endpoint in the study, as measured by the change from baseline on the PANSS NSFS at Day 84, Luvadaxistat met secondary endpoints of cognitive assessment, which merit further clinical evaluation. ${ }^{13}$ The improvement of cognitive function for TAK-831 in schizophrenic patients is consistent with improvement of cognitive performance in rodent models. For example, another DAO inhibitor SEP-227900 increased D-serine in the cerebellum of rats in a dose dependent manner, and pretreatment of rats with this DAO inhibitor increased memory of the test object in the novel object recognition model in rats, suggesting improved cognitive function. ${ }^{14}$

There are many published DAO co-crystal structures in the literature. Figure 2 shows the co-crystal structure of human DAO enzyme with a hydroxy pyridazinone ligand (11), which was one of the most potent DAO inhibitors reported by both Takeda and Astellas. ${ }^{7}$ Overall, the ligand adopts an L-shaped conformation in the binding site. The hydroxy pyridazinone head group is stacked between the flavin ring of FAD (flavin adenine dinucleotide) and Tyr224. The hydroxy-carbonyl moiety forms a salt bridge with Arg283, and the N-H forms an H-bond with Gly313. On the other side, the phenyl ring sticks into a relatively hydrophobic pocket and stacks with Tyr224 to form a $\pi$ edge interaction. 


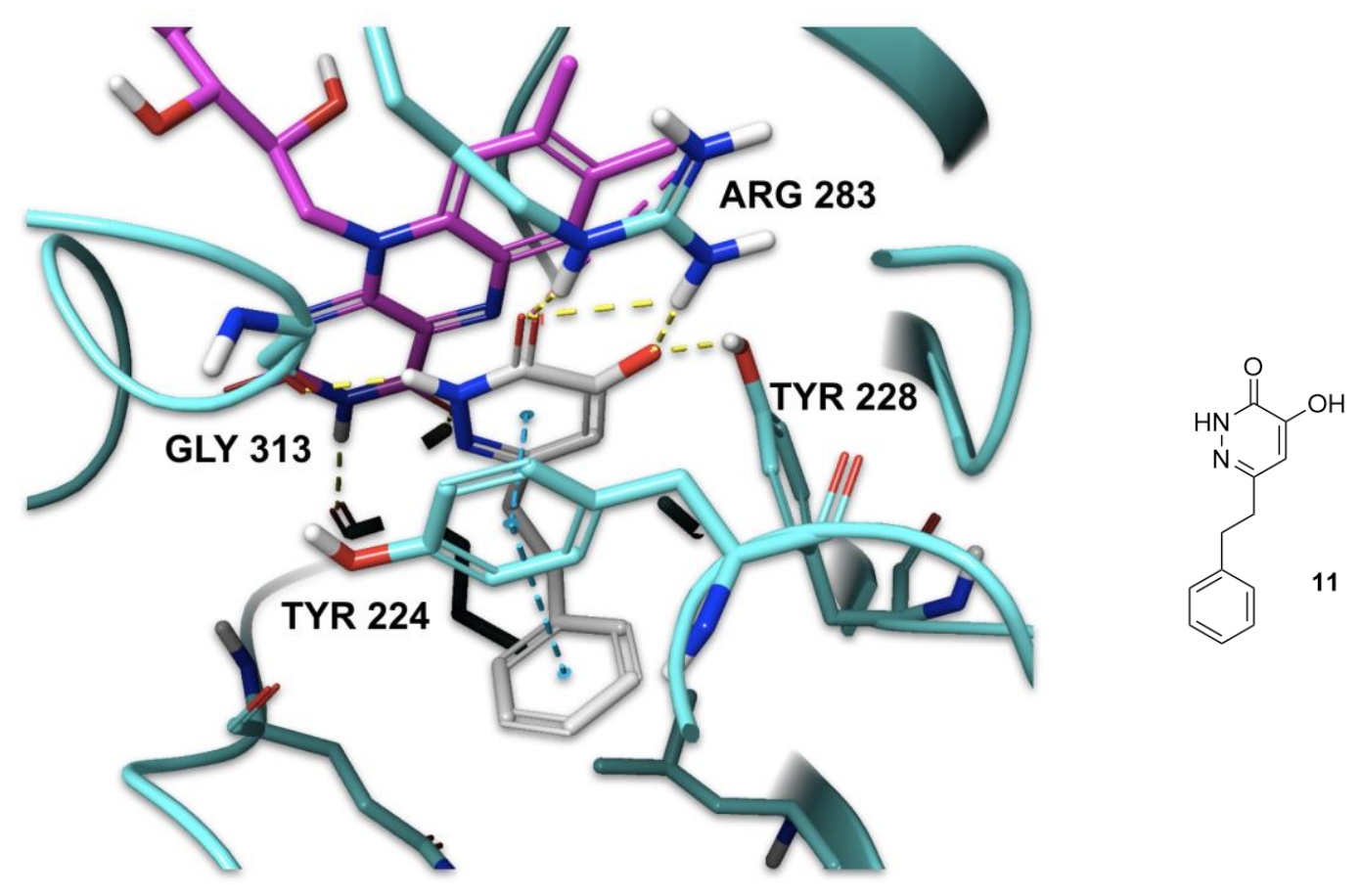

Figure 2. Co-crystal structure of human DAO with compound 11 (PDB: 3W4K) in grey and coenzyme FAD in magenta.

Intrigued by the target biology and therapeutic potential for treatment of cognitive impairment in schizophrenia or other neurological disorders, we initiated a program to identify novel DAO inhibitors with best-in-class properties. The program leveraged the Schrödinger physics-based modeling technology, specifically, a human DAO Free Energy Perturbation (FEP+) model which was developed on the basis of published SAR data. ${ }^{15}$ Key protein-ligand interactions presented in the co-crystal structures were taken into account as novel ligands were designed by multiple internal medicinal and computational chemists. The designs were further evaluated with the hDAO FEP+ model, and the top ideas were prioritized for synthesis. Among them (Table 1), 12, 13 and $\mathbf{1 4}^{16}$ showed good hDAO biochemical potency, which is consistent with the FEP+ model prediction. ${ }^{17}$ Thanks to their low molecular weights, all three compounds have good ligand efficiency (LE) and lipophilic ligand efficiency (LLE). Initially SAR work indicated that various substituents can be tolerated on the phenyl ring of both dihydropyrazine dione (12, DHP dione) and N-hydroxyl pyrimidine dione (13, NHP dione) hit classes. For instance, the $\mathrm{CF}_{3}$ group of $\mathbf{1 2}$ can be replaced with a chlorine to yield $\mathbf{1 5}$ which shares similar DAO potency. Similarly, a chlorine can be incorporated at the para-position of $\mathbf{1 3}$ to afford $\mathbf{1 6}$, which is slightly more potent than $\mathbf{1 3}$. In order to understand the in vivo pharmacokinetic (PK) properties of the hits, especially their ability to cross the blood-brain barrier (BBB), compounds $\mathbf{1 4}, \mathbf{1 5}$, and 16 were dosed as a cassette in mice along with $17^{18}$ (Table 3 ) as a reference compound.

Table 1. Novel DAO inhibitors identified by FEP+ enabled lead hopping

\begin{tabular}{|c|c|c|c|c|c|c|}
\hline $\begin{array}{c}\text { Compound } \\
\text { ID }\end{array}$ & Chemical Structure & $\begin{array}{c}\text { FEP+ Pred. } \\
\mathrm{IC}_{50}(\mu \mathrm{M})\end{array}$ & $\begin{array}{c}\text { hDAO IC } 50 \\
(\mu \mathrm{M})\end{array}$ & LE & LLE & $\begin{array}{c}\text { Papp A } \rightarrow \mathrm{B} \\
\left(10^{-6} \mathrm{~cm} / \mathrm{s}\right), \mathrm{ER}\end{array}$ \\
\hline $\mathbf{1 2}$ & \\
\hline
\end{tabular}




\begin{tabular}{|l|l|l|l|l|l|l|}
\hline 13 & 0.034 & 0.028 & 0.62 & 7.1 & $15,0.4$ \\
\hline 14 & 0.12 & 0.12 & 0.88 & 6.5 & $8.8,0.8$ \\
\hline 15 & & 0.22 & 0.32 & 0.53 & 4.4 & $12,0.4$ \\
\hline
\end{tabular}

Overall, compound 17 showed good plasma exposure following oral dosing but poor CNS exposure with a measured Kp,uu (brain/plasma) of $0.01 .{ }^{19}$ Compound $\mathbf{1 5}$ also has good plasma exposure with relatively low clearance in the study. The brain exposure, however, is also lower than the plasma exposure with a Kp of 0.17. Due to lower free brain fraction than free plasma fraction, the Kp,uu was further reduced to 0.04. Nevertheless, the PK and brain penetration data of $\mathbf{1 5}$ suggests that the DHP dione hit class is suitable for hit-to-lead development. The NHP dione series suffers from high clearance across all analogs we profiled, as exemplified by compound 16. Compound 14 exhibits a low clearance and an acceptable oral bioavailability in the plasma. However, the level of brain exposure was very low. In addition, the thiophene pyrazine hit class had limited opportunity for potency improvement and narrow existing SAR. Based on the data, the NHP dione and thiophene pyrazine hit classes were deprioritized, and further work was focused on the development of the DHP dione hit class.

Table 2. Mouse PK and brain distribution data

\begin{tabular}{|l|l|c|c|c|c|}
\hline \multicolumn{1}{|c|}{ Study } & & $\mathbf{1 7}$ & $\mathbf{1 5}$ & $\mathbf{1 6}$ & $\mathbf{1 4}$ \\
\hline & CL (mL/min/kg) & 3.6 & 5.9 & 108 & 1.8 \\
& Vdss (L/kg) & 0.5 & 1.0 & 1.9 & 0.2 \\
PK study with C57/BL6 & t1/2, IV (h) & 2.5 & 2.4 & NR & 1.2 \\
mice: & AUCN, po (ng*h/mL) & 2407 & 2175 & 13.6 & 6266 \\
Cassette dosing with 2 & F\% & 51 & 77 & 9 & 34 \\
mg/kg po and 0.5 mg/kg & Kp (brain/plasma) & $0.02^{*}$ & $0.17^{*}$ & BLQ & $0.004^{* *}$ \\
IV; $=3$ & Fu, plasma (brain) & $0.17(0.1)$ & $0.20(0.05)$ & BLQ & $0.22(0.26)$ \\
& Kp,uu (brain/plasma) & $0.01^{*}$ & $0.04^{*}$ & BLQ & $0.005^{* *}$ \\
\hline
\end{tabular}

* Calculated from PO AUC; ${ }^{\star *}$ Calculated from IV AUC

To understand the binding interactions of the DHP dione chemical series, a co-crystal structure of $\mathbf{1 2}$ was obtained via a soaking experiment with the hDAO apo crystal. As shown in Figure 3, compound $\mathbf{1 2}$ binds to the hDAO enzyme in a fashion very similar to ligand $\mathbf{1 1}$. The dihydropyrazine dione head group is stacked between the flavin ring and Tyr224. The hydroxy-carbonyl moiety forms a salt bridge with $\operatorname{Arg} 283$, and the $\mathrm{NH}$ forms H-bond with Gly313. On the tail side, the 4-trifluoromethyl phenyl sticks into the hydrophobic pocket. Unlike the acidic hydroxy pyridazinone head group in compound $\mathbf{1 1}$, the pKa of $\mathbf{1 2}$ was measured at $9.7,{ }^{20}$ which would imply a pKa penalty in binding to DAO, as only the anionic form can actively bind to DAO. In addition, the head group of $\mathbf{1 2}$ is pseudosymmetric with two possible anionic tautomers, and substitution on the head group can impact the tautomer 
distribution. Fortunately, quantum mechanics (QM) calculations suggested that the active tautomer is strongly favored for 12, by $0.8 \mathrm{kcal} / \mathrm{mol}$. Although the DHP dione chemical series is relatively weaker than the hydroxy pyridazinone $^{21}$ chemical series due to the higher $\mathrm{pKa}$ of the head group, it may benefit from other properties such as pharmacokinetics and brain penetration.

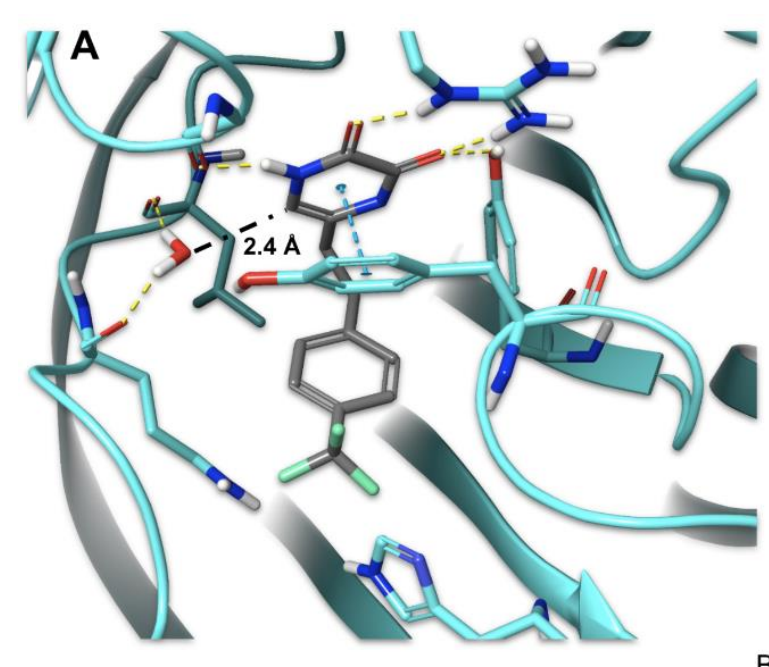

B
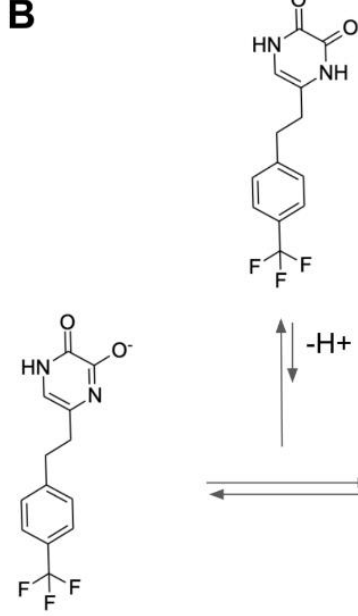

Bio-active tautomer

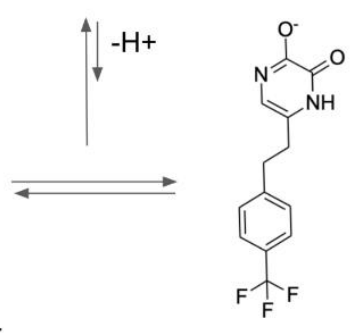

Figure 3. (a) Co-crystal structure of human DAO with compound 12; (b) Equilibrium of 12 (approx. 80\% QM predicted preference for the bio-active tautomer (left) vs the alternative tautomer (right))

\section{SAR DEVELOPMENT}

Initial SAR exploration was focused on the aromatic tail region of compound 12. Both rational design by medicinal chemists and computational enumeration by Schrödinger's AutoDesigner algorithm were applied to generate a diverse set of design ideas. The large number of designs were filtered by molecular properties, a CNS MPO, a druglikeness MPO and synthetic tractability, etc. The top scoring designs were progressed into FEP+ calculations to predict hDAO inhibitory potency. The compounds with favorable predicted hDAO potency were selected for synthesis at Charles River Laboratories (CRL). Additionally, active compounds were tested in the MDCK-MDR1 assays to assess cell permeability and efflux ratio (ER).

Compound 17 was also included in Table 3 as a reference compound, which was measured $17 \mathrm{nM}$ in the hDAO biochemical assay. It is slightly right shifted in the hDAO cell assay, but about 4-fold left shifted in the mouse DAO cell assay. In the DHP dione chemical series, para-substitution on the phenyl ring is beneficial to potency, as the unsubstituted analog 18 is much less active. At the para-position, $\mathrm{CN}$ substitution (19) can also be tolerated in addition to $\mathrm{Cl}$, while the methoxy analog $\mathbf{2 0}$ is less potent. From the mono $\mathrm{Cl}$-substituted analogs 15, 21, and $\mathbf{2 2}$, para-substitution is the most preferred, while ortho-substitution is not tolerated. Compound $\mathbf{1 9}$ can be substituted with a fluorine ortho to the cyano group as in analog $\mathbf{2 3}$, while 3,5-dichloro substituted analog $\mathbf{2 4}$ is less active when compared to the mono-substituted analog $\mathbf{2 1}$. The tail region tolerates other hetero aromatic rings such as pyridine (25) and bicyclic aromatic rings such as quinoline (26) with some loss of potency. Polar groups can also be tolerated in this region as exemplified by compound $\mathbf{2 7}$ and $\mathbf{2 8}$. It is worth noting that both compound $\mathbf{2 7}$ and $\mathbf{2 8}$ were designed by the AutoDesigner algorithm featuring uncommon yet drug-like functionalities. In terms of hDAO $\mathrm{FEP}+$ model performance, the majority of the prediction is within $1 \log$ unit of the experimental $\mathrm{IC}_{50}$ value. Compared to 17, most analogs showed lower but moderate cell permeability and low efflux ratio in the MDCKMDR1 assay, which may partially account for the near 10-fold shift in the hDAO cell assay. To ensure that the compound activity is not an artifact from their redox potential, the horseradish peroxidase assay (HRP) was developed as a counter screen. All compounds in Table 3 were shown to be clean up to $10 \mu \mathrm{M}$ in the HRP assay. 
Table 3. Tail SAR of the DHP dione chemical series

\begin{tabular}{|c|c|c|c|c|c|c|}
\hline $\begin{array}{l}\text { Compound } \\
\text { ID }\end{array}$ & Chemical Structure & $\begin{array}{c}\text { FEP+ Pred. } \\
I_{50}(\mu \mathrm{M})\end{array}$ & $\begin{array}{l}\mathrm{hDAO} \mathrm{IC}_{50} \\
(\mu \mathrm{M})\end{array}$ & $\begin{array}{l}\text { hDAO Cell } \\
\mathrm{EC}_{50}(\mu \mathrm{M})\end{array}$ & $\begin{array}{l}\text { mDAO Cell } \\
\mathrm{EC}_{50}(\mu \mathrm{M})\end{array}$ & $\begin{array}{c}\text { Papp A } \rightarrow \text { B } \\
\left(10^{-6} \mathrm{~cm} / \mathrm{s}\right), \mathrm{ER}\end{array}$ \\
\hline 17 & & ND & 0.017 & 0.029 & 0.0042 & $53,0.8$ \\
\hline 12 & & 0.011 & 0.34 & 3.1 & 1.6 & $11,0.7$ \\
\hline 18 & & 2.2 & 5.8 & ND & ND & $4,0.4$ \\
\hline 15 & & 0.22 & 0.32 & 3.3 & 0.85 & $12,0.4$ \\
\hline 19 & & 0.16 & 0.19 & 1.8 & 1.5 & $3.0,0.6$ \\
\hline 20 & & 0.71 & 1.6 & ND & ND & $3,0.4$ \\
\hline 21 & & 0.49 & 0.47 & 3.5 & ND & $6.8,0.9$ \\
\hline 22 & & 1.5 & 6.2 & ND & ND & ND \\
\hline 23 & & 0.097 & 0.18 & 1.9 & ND & $3.3,0.5$ \\
\hline 24 & & 0.25 & 2.5 & ND & ND & ND \\
\hline 25 & & 0.060 & 0.67 & 8.2 & ND & ND \\
\hline
\end{tabular}




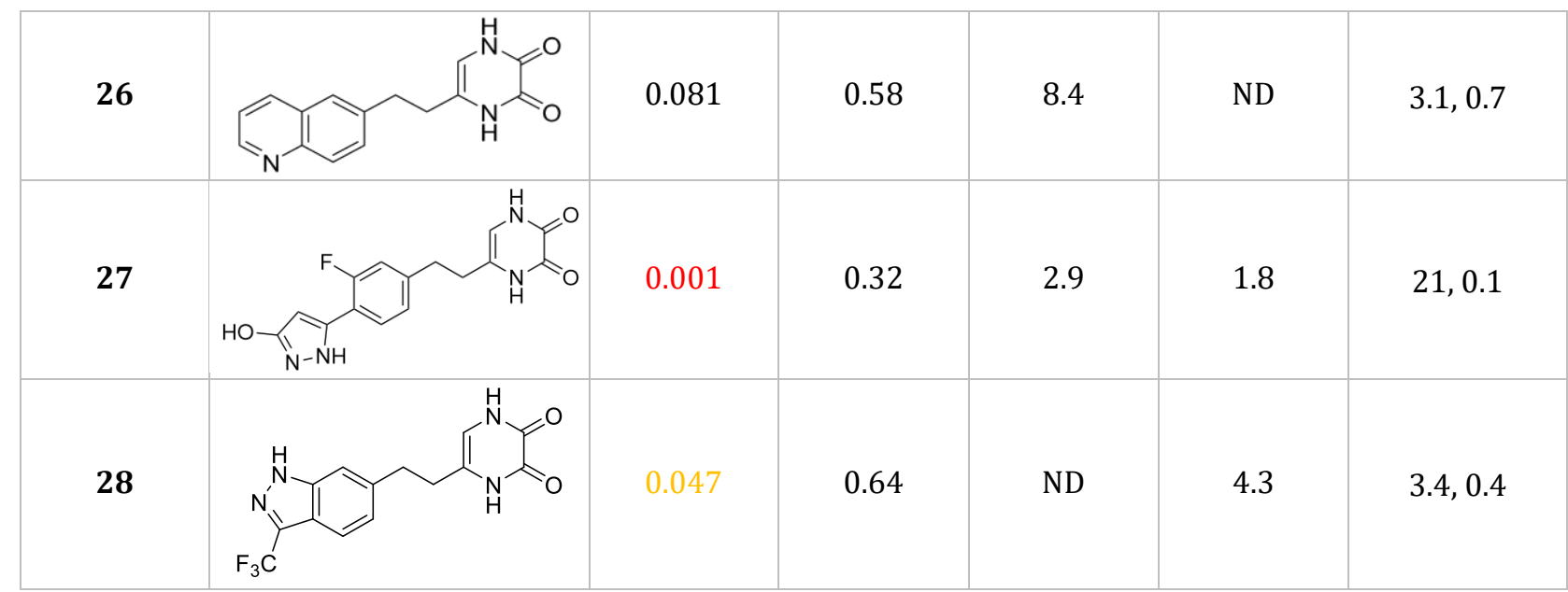

ND: No data

In the $\mathrm{hDAO}$ co-crystal structure of $\mathbf{1 2}$, there is a water molecule $2.4 \AA$ away from the $6-\mathrm{H}$ of the dihydropyrazine dione head group (Figure 3a). It is possible to substitute at the 6-position to interact with or even replace the water molecule. In addition, the substituents may also modify the pKa of the head group. Table 4 includes a subset of analogs that were explored in this area. The Cl-substituted analog 29 was predicted to be quite potent by FEP+. However, it was found to be much less active in the hDAO assay. A QM calculation later suggested that the $\mathrm{Cl}$ substitution would strongly disfavor the bio-active tautomer to about $1 \%$ due to electronic effects. Attempts were also made to synthesize the F-substituted analog 30, as fluorine is much less electron donating than chlorine, and it was also predicted to have much lower pKa (Macro-pKa 5.7) than 12. Unfortunately, compound 30 proved to be unstable during synthesis. The methyl substituted analog $\mathbf{3 1}$ was also synthesized. However, it was much less active in the hDAO biochemical assay than predicted by the FEP+ model, suggesting hydrophobic groups are not tolerated at this position. Also interesting is the cyano analog 32, which was measured to have much lower pKa (6.4) than 12. Compound $\mathbf{3 2}$ showed similar potency to $\mathbf{1 2}$ as predicted by FEP+, and it showed lower cell shift in both the human and mouse DAO cell assays.

Table 4. C-6 SAR of the DHP dione chemical series

\begin{tabular}{|c|c|c|c|c|c|c|}
\hline $\begin{array}{l}\text { Compound } \\
\text { ID }\end{array}$ & Chemical Structure & $\begin{array}{l}\text { FEP Pred. } \text { IC }_{50} \\
(\mu \mathrm{M})\end{array}$ & $\begin{array}{l}\text { hDAO IC } 50 \\
(\mu \mathrm{M})\end{array}$ & $\begin{array}{l}\text { hDAO Cell } \\
\mathrm{EC}_{50}(\mu \mathrm{M})\end{array}$ & $\begin{array}{c}\text { mDAO Cell } \\
\mathrm{EC}_{50}(\mu \mathrm{M})\end{array}$ & $\begin{array}{c}\text { Papp A } \rightarrow \text { B } \\
\left(10^{-6} \mathrm{~cm} / \mathrm{s}\right), \text { ER }\end{array}$ \\
\hline 29 & & 0.0028 & 1.5 & 0.50 & ND & $8.1,0.7$ \\
\hline 30 & & 0.047 & NA & NA & NA & NA \\
\hline 31 & & 0.050 & 3.9 & ND & ND & $4.8,2.4$ \\
\hline
\end{tabular}




\begin{tabular}{|l|l|l|l|l|l|}
\hline 32 & & 0.19 & 0.25 & 0.54 & 0.34 \\
\hline
\end{tabular}

SAR of the linker region was also explored (Table 5). In terms of the linker length, the 2-carbon linker (18) is superior to the 3-carbon linker (33) according to the FEP+ predictions. ${ }^{22}$ It is also better than the 1-carbon linker based on the matched pair of $\mathbf{1 5}$ and 34. Analogs with fluorinated linker (i.e. 35) are also interesting, as fluorinesubstituted linkers were predicted to lower the pKa of the head group. However, compound $\mathbf{3 5}$ failed in the synthesis due to chemical stability issues. Linkers with hetero atoms were also explored. Although analogs with an oxygen linker failed in synthesis, the sulfur-linked analogs are stable enough for further SAR development. Encouragingly, both 36 and $\mathbf{3 7}$ are about 3-fold more potent than 12 in the hDAO biochemical assay. The enhancement in biochemical potency may partly be attributed to lower pKa's of the head groups in $\mathbf{3 6}$ and $\mathbf{3 7}$. Compound $\mathbf{3 6}$ has a measured $\mathrm{pKa}$ of 8.5, and compound $\mathbf{3 7}$ 9.2. Compared to $\mathbf{1 2}$ with a $\mathrm{pKa}$ of $9.7, \mathbf{3 6}$ and $\mathbf{3 7}$ are more favored to form the bio-active anionic structures. In addition, they both show a lower cell shift when compared to 12, possibly due to moderately higher cell permeability as measured in the MDCK-MDR1 assay.

Table 5. Linker SAR in the DHP dione chemical series

\begin{tabular}{|c|c|c|c|c|c|c|}
\hline Compound ID & Chemical Structure & $\begin{array}{l}\text { FEP Pred. } \\
\mathrm{IC}_{50}(\mu \mathrm{M})\end{array}$ & $\begin{array}{c}\mathrm{hDAO}^{\mathrm{I} \mathrm{I}_{50}} \\
(\mu \mathrm{M})\end{array}$ & $\begin{array}{l}\text { hDAO Cell } \\
\text { EC }_{50}(\mu \mathrm{M})\end{array}$ & $\begin{array}{l}\text { mDA0 Cell } \\
\mathrm{EC}_{50}(\mu \mathrm{M})\end{array}$ & $\begin{array}{c}\text { Papp } A \rightarrow B \\
\left(10^{-6} \mathrm{~cm} / \mathrm{s}\right), \text { ER }\end{array}$ \\
\hline 33 & & 61 & NA & NA & NA & NA \\
\hline 34 & & 13 & 3.3 & ND & ND & ND \\
\hline 35 & & 0.084 & NA & NA & NA & NA \\
\hline 36 & & 0.034 & 0.091 & 0.42 & 0.24 & $18,0.3$ \\
\hline 37 & & 0.040 & 0.092 & 0.60 & 0.51 & $14,0.4$ \\
\hline
\end{tabular}

NA: Not available because the compound was not synthesized.

The tail SAR of the sulfur-linked analogs $\mathbf{3 6}$ and $\mathbf{3 7}$ largely resembles that of $\mathbf{1 2}$ (Table 6). Further exploration of the tail SAR of sulfur-linked analogs led to significant potency improvement in the hDAO biochemical and cell assays. In addition to $\mathrm{Cl}(38 \& 39)$ and $\mathrm{CN}$ (40), difluoro methyl (41 \& 42), methyl sulfone (43 \& 44$)$ and pentafluoro sulfanyl (45 \& 46) groups can be tolerated at the para-position. In general, para-substitution is still the most preferred, while meta-substitution clearly reduces potency (40 vs. $\mathbf{4 7}$ ). The ortho-CN substituted analog (not shown) was predicted to be $26 \mu \mathrm{M}$ by the FEP+ model. As demonstrated by $\mathbf{4 8}$, the phenyl ring can be replaced with 
a pyridine ring with some loss of potency. Di-substitutions can be tolerated at the para and meta-positions as exemplified by compounds $49, \mathbf{5 0}, \mathbf{5 1}$, and $\mathbf{5 2}$. The tail region can also tolerate bicyclic aromatic rings as exemplified by 53, a compound designed by our AutoDesigner algorithm. In terms of cell potency, the sulfur-linked compounds tend to be less right shifted in the DAO cell assays compared to the carbon linked analogs, which is desirable. However, analogs with polar substituents tend to have larger cell shifts possibly due to decreased cell permeability (e.g. 42, 44, and 51).

Table 6. SAR of sulfur-linked analogs

\begin{tabular}{|c|c|c|c|c|c|c|}
\hline $\begin{array}{l}\text { Compound } \\
\text { ID }\end{array}$ & Chemical Structure & $\begin{array}{l}\text { FEP Pred. } \\
\text { IC }_{50}(\mu \mathrm{M})\end{array}$ & $\begin{array}{l}\mathrm{hDAO} \mathrm{IC}_{50} \\
(\mu \mathrm{M})\end{array}$ & $\begin{array}{l}\text { hDAO Cell } \\
\mathrm{EC}_{50}(\mu \mathrm{M})\end{array}$ & $\begin{array}{l}\text { mDAO Cell } \\
\mathrm{EC}_{50}(\mu \mathrm{M})\end{array}$ & $\begin{array}{c}\text { Papp A } \rightarrow \text { B } \\
\left(10^{-6} \mathrm{~cm} / \mathrm{s}\right), \text { ER }\end{array}$ \\
\hline 38 & & 0.36 & 0.15 & 0.40 & 0.51 & $19,0.6$ \\
\hline 39 & & 0.25 & 0.13 & 0.68 & 0.39 & $11,0.4$ \\
\hline 40 & & 0.24 & 0.043 & 0.25 & 0.31 & $4.4,0.4$ \\
\hline 41 & & 0.26 & 0.070 & 0.45 & 0.59 & $8.9,0.4$ \\
\hline 42 & & 0.27 & 0.072 & 0.62 & 0.62 & $5.6,0.4$ \\
\hline 43 & & 0.097 & 0.090 & 0.44 & 0.54 & $0.9,1.1$ \\
\hline 44 & & 0.60 & 0.082 & 0.83 & 2.3 & $1.7,0.4$ \\
\hline 45 & & 0.078 & 0.097 & 0.38 & 0.50 & $15,0.7$ \\
\hline
\end{tabular}




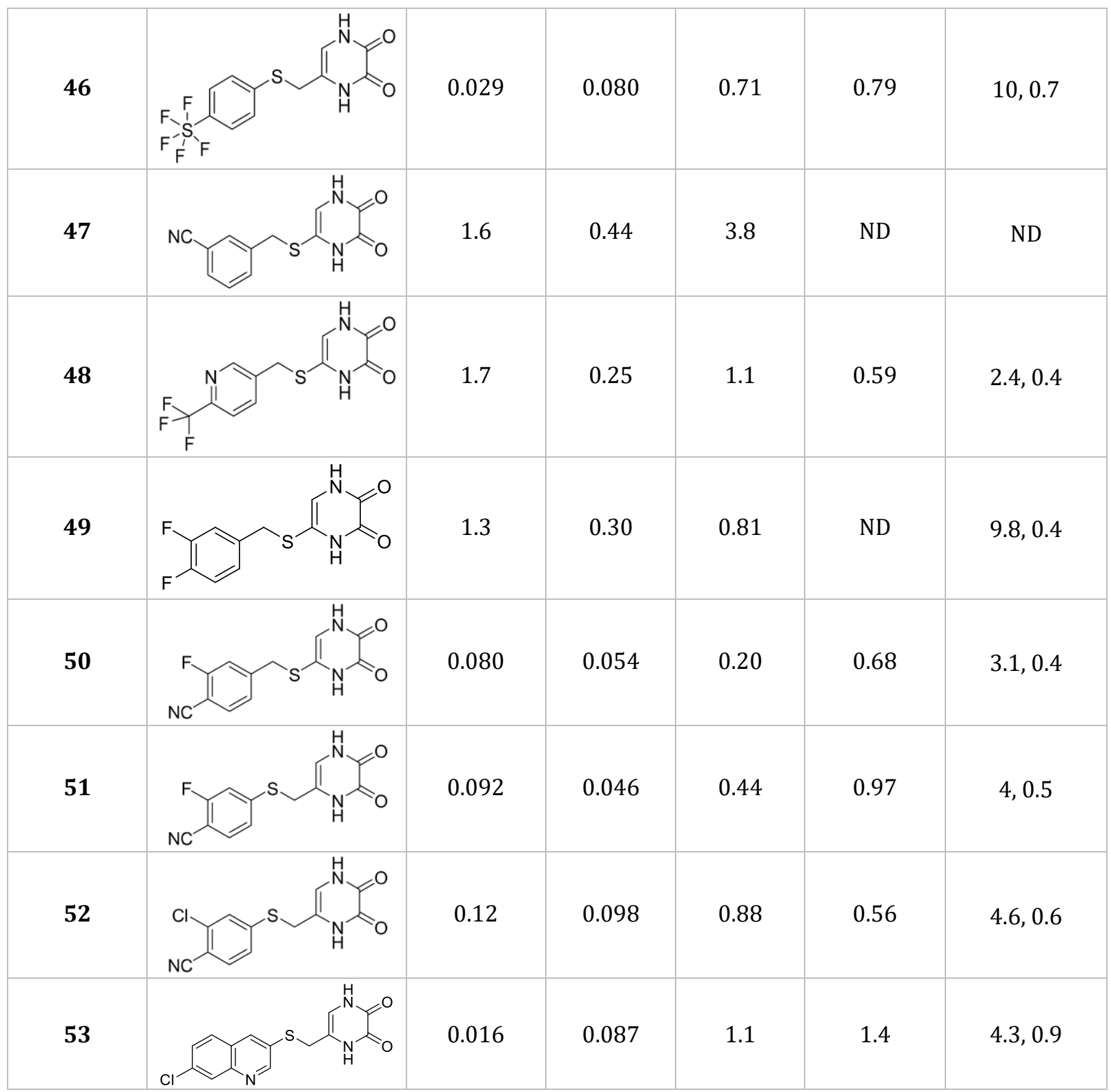

In order to further enhance compound inhibitory potency against hDAO, fused ring designs in the linker region were also assessed by the FEP+ model. One of the ideas that stood out was $\mathbf{5 4}$, which was designed by cyclizing the linker of $\mathbf{3 7}$ to form a fused 1,4-oxathiane ring. It was predicted that cyclization would lead to a gain in potency resulting at least in part from stabilization of the linker and tail piece. FEP+ predicted this compound to be a $3 \mathrm{nM}$ inhibitor in the hDAO assay (Figure 4a). To our delight, the compound showed an $\mathrm{IC}_{50}$ of $25 \mathrm{nM}$ in the assay, a 3fold improvement from 37. Thus, cyclized analogs with the best substituents from the chemical series were prepared. Most of these analogs showed significant improvement when compared to their acyclic counterparts in the hDAO biochemical assay. However, there was less improvement in the human and mouse cell DAO assays due to larger cell shift for the cyclized analogs. The binding mode of the cyclized analogs was confirmed by X-ray cocrystal structure of $\mathbf{5 9}$ (Figure $4 \mathrm{~b}$ ), which very much resembles the FEP+ snapshot of compound $\mathbf{5 4}$ binding to hDAO. The biggest changes are in the tail region due to different substituents at the para-position. 


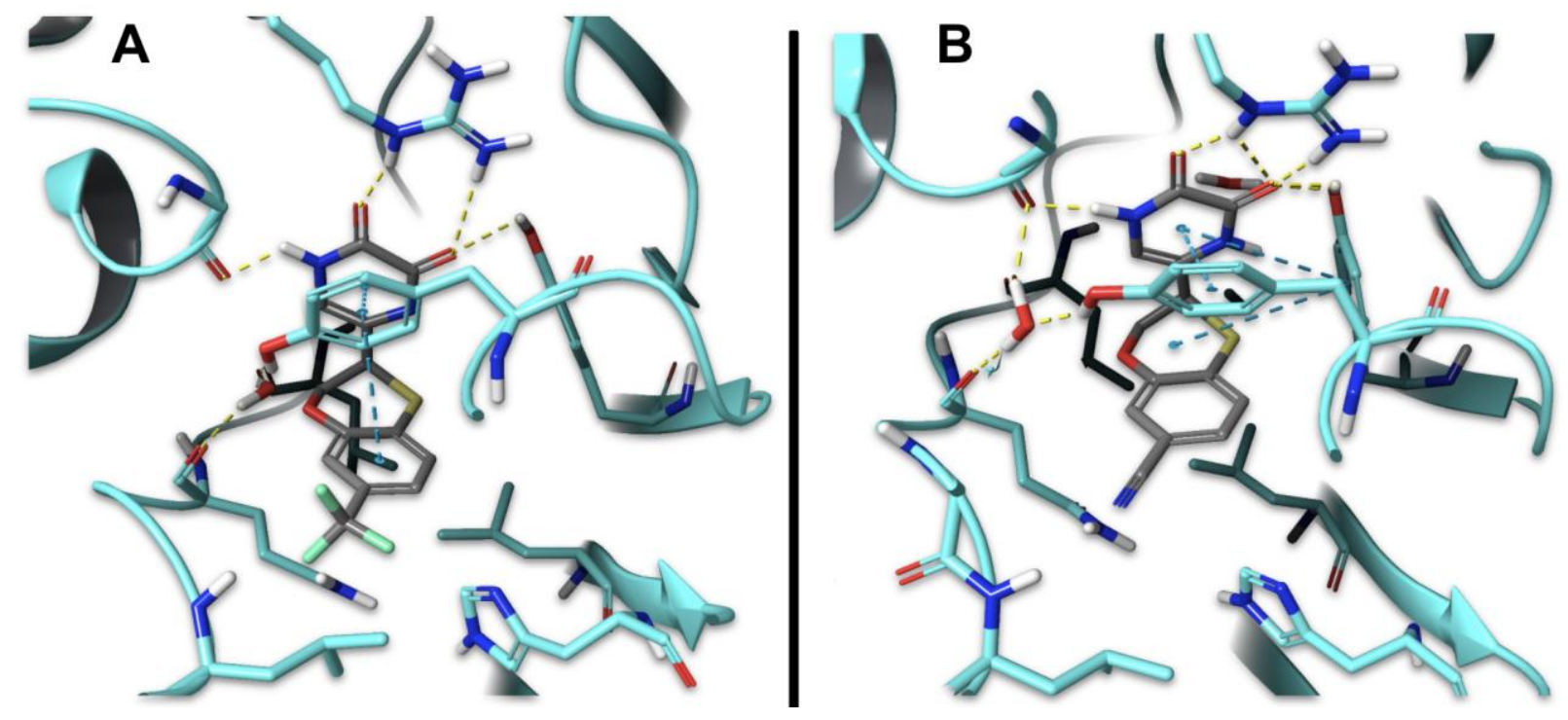

Figure 4. (A) FEP+ snapshot of compound 54 binding to hDAO. (B) Crystal structure of compound 59.

Table 7. SAR of the fused 1,4-oxathiane analogs

\begin{tabular}{|c|c|c|c|c|c|c|}
\hline $\begin{array}{l}\text { Compound } \\
\text { ID }\end{array}$ & Chemical Structure & $\begin{array}{l}\text { FEP Pred } \\
\text { IC }_{50}(\mu \mathrm{M})\end{array}$ & $\begin{array}{l}\text { hDAO IC } 50 \\
\quad(\mu \mathrm{M})\end{array}$ & $\begin{array}{l}\text { hDAO Cell } \\
\mathrm{EC}_{50}(\mu \mathrm{M})\end{array}$ & $\begin{array}{c}\text { mDAO Cell } \\
\mathrm{EC}_{50}(\mu \mathrm{M})\end{array}$ & $\begin{array}{c}\text { Papp A } \rightarrow \text { B } \\
\left(10^{-6} \mathrm{~cm} / \mathrm{s}\right), \mathrm{ER}\end{array}$ \\
\hline 54 & & 0.003 & 0.025 & 0.29 & 0.43 & ND \\
\hline 55-rac & & $0.049^{\#}$ & 0.406 & 1.76 & 0.72 & ND \\
\hline 56 & & 0.039 & 0.094 & 0.56 & 0.54 & $7.6,0.3$ \\
\hline 57 & & 0.033 & 0.021 & 0.14 & 0.22 & $15,0.5$ \\
\hline 58 & & 0.062 & 0.013 & 0.13 & 0.29 & ND \\
\hline 59 & & 0.0017 & 0.020 & 0.63 & 0.78 & $3.1,0.5$ \\
\hline
\end{tabular}




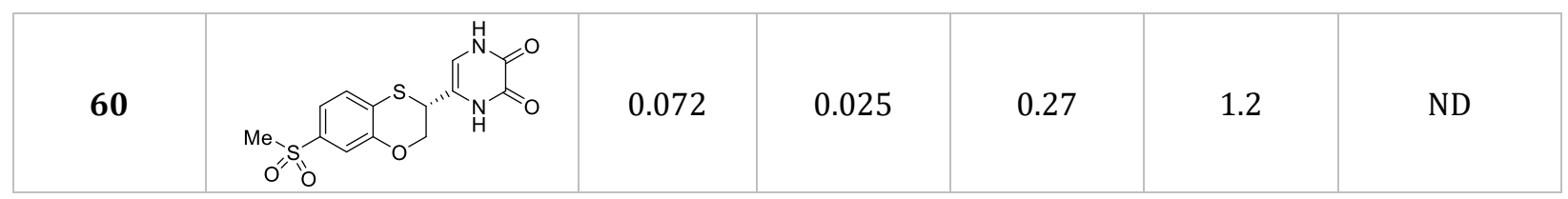

\#FEP+ model prediction was for the eutomer.

Another interesting design on the cyclized analogs is quaternary methyl adduct $\mathbf{6 1}$. While this methyl addition was not initially predicted by our FEP+ model to lead to any gain in potency when compared to the des-methyl analog $\mathbf{5 5}$, the racemic quaternary methyl 61- $\mathrm{rac}^{23}$ was tested to be about 5-fold more potent than 55-rac. That is because we did not have more closely related starting references for our FEP+ model at the time of the original prediction for 61. Subsequently we troubleshooted the FEP+ model by using the more closely related des-methyl analog $\mathbf{5 5}$ as the starting reference and observed that the methyl group displaces a high-energy water molecule concurrent with a predicted gain of potency (Figure 5). The quaternary methyl group was incorporated into other analogs and resulted in roughly 2-fold improvement in DAO biochemical and cellular assays. Notably, compound $\mathbf{6 3}$ showed inhibition potency near $100 \mathrm{nM}$ in both human and mouse DAO cell assays.
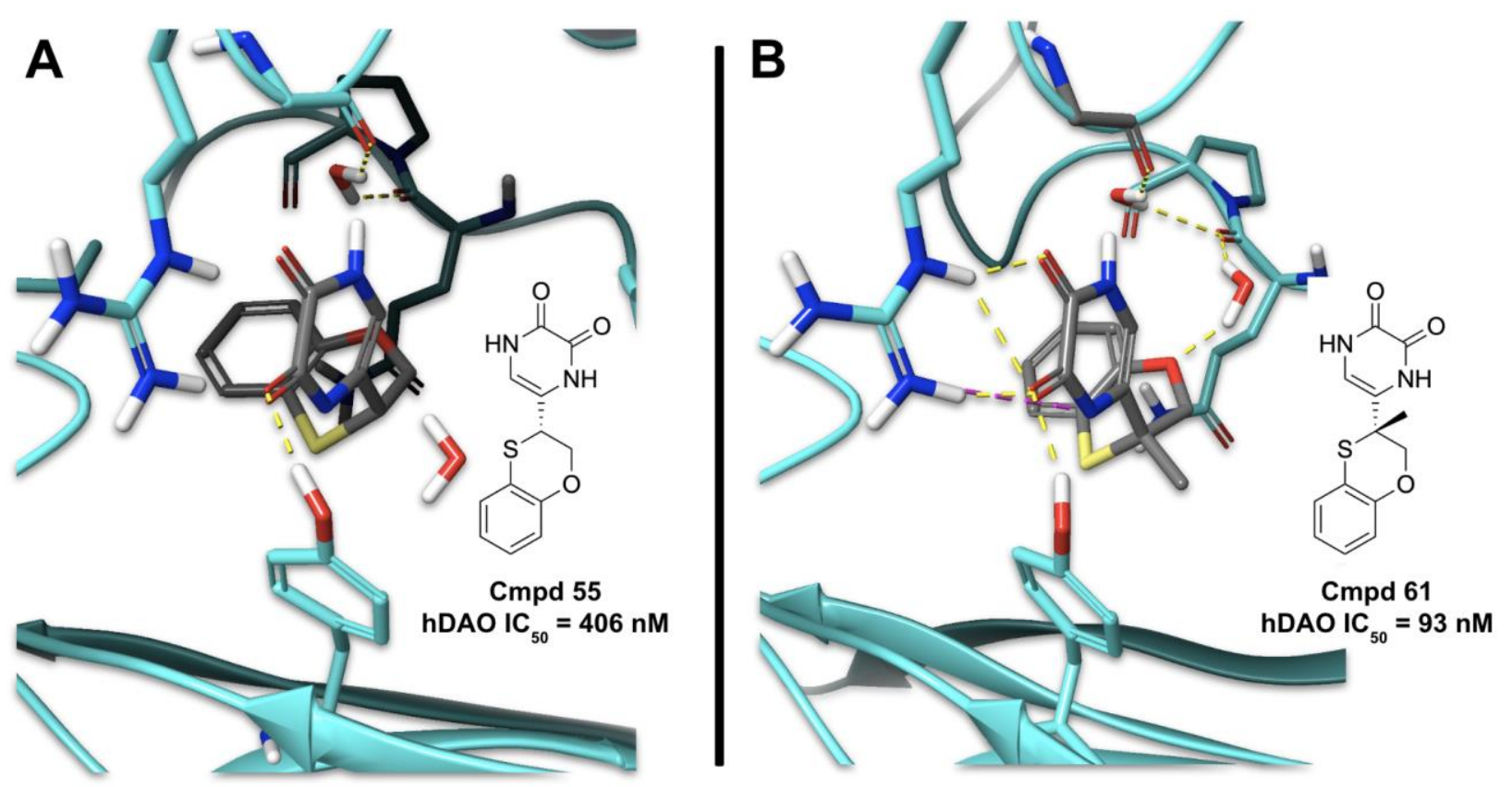

Figure 5. (a) FEP+ snapshot of compound 55 binding to hDAO. (b) 61 binding to hDAO.

Table 8. Key analogs with the quaternary methyl group

\begin{tabular}{|c|c|c|c|c|c|}
\hline $\begin{array}{c}\text { Compound } \\
\text { ID }\end{array}$ & Chemical Structure & $\begin{array}{c}\text { FEP Pred. } \\
\mathrm{IC}_{50}(\mu \mathrm{M})\end{array}$ & $\begin{array}{c}\mathrm{hDAO} \text { IC } \\
(\mu \mathrm{M})\end{array}$ & $\begin{array}{c}\mathrm{hDAO} \text { Cell } \\
\mathrm{EC}\end{array}$ & $\begin{array}{c}\text { mDAO Cell } \\
\mathrm{EC}_{50}(\mu \mathrm{M})\end{array}$ \\
\hline $\mathbf{6 1 - \mathrm { rac }}$ & \\
\hline
\end{tabular}




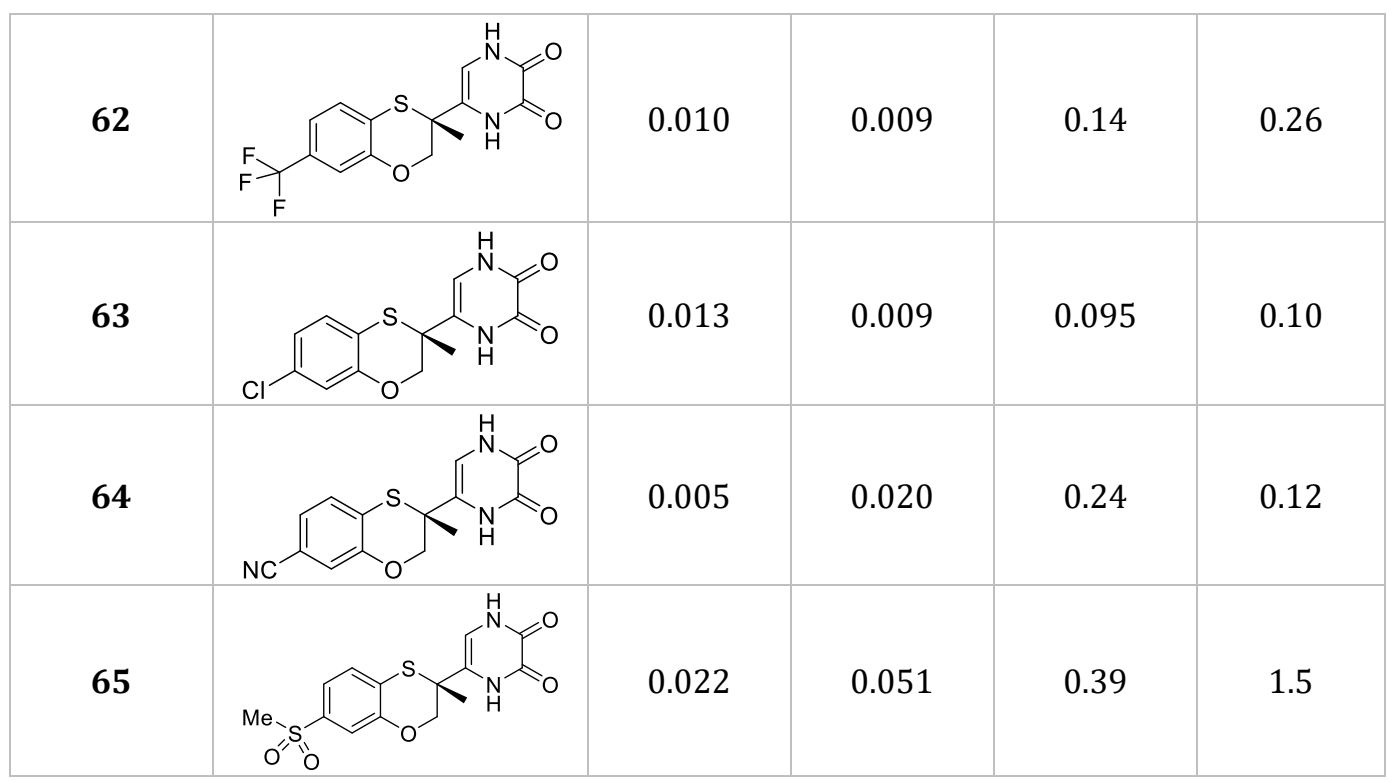

In an effort to explore new opportunities for potency enhancement, careful examination of the DAO catalytic site revealed a subpocket just beyond the tail region, which was not explored by other groups (Figure 6a). In order to design into this subpocket, we employed our AutoDesigner algorithm to enumerate novel design ideas using compound $\mathbf{5 4}$ as a template. Initially over 198 million design ideas were generated by the algorithm, which were filtered by an array of criteria such as molecular properties, CNS and drug-like MPO's, and synthetic complexity. After GLIDE docking into the hDAO crystal structure, the surviving compounds were evaluated by the hDAO FEP+ model for potency. Only three top compounds were selected for synthesis, among which compound $\mathbf{6 6}$ stood out as a single digit $\mathrm{nM} \mathrm{hDAO}$ inhibitor on the project. With just one round of synthesis, we were able to confirm that the subpocket is a viable design space to further enhance compound binding potency to the hDAO enzyme, which opens up much needed new SAR space for this target.
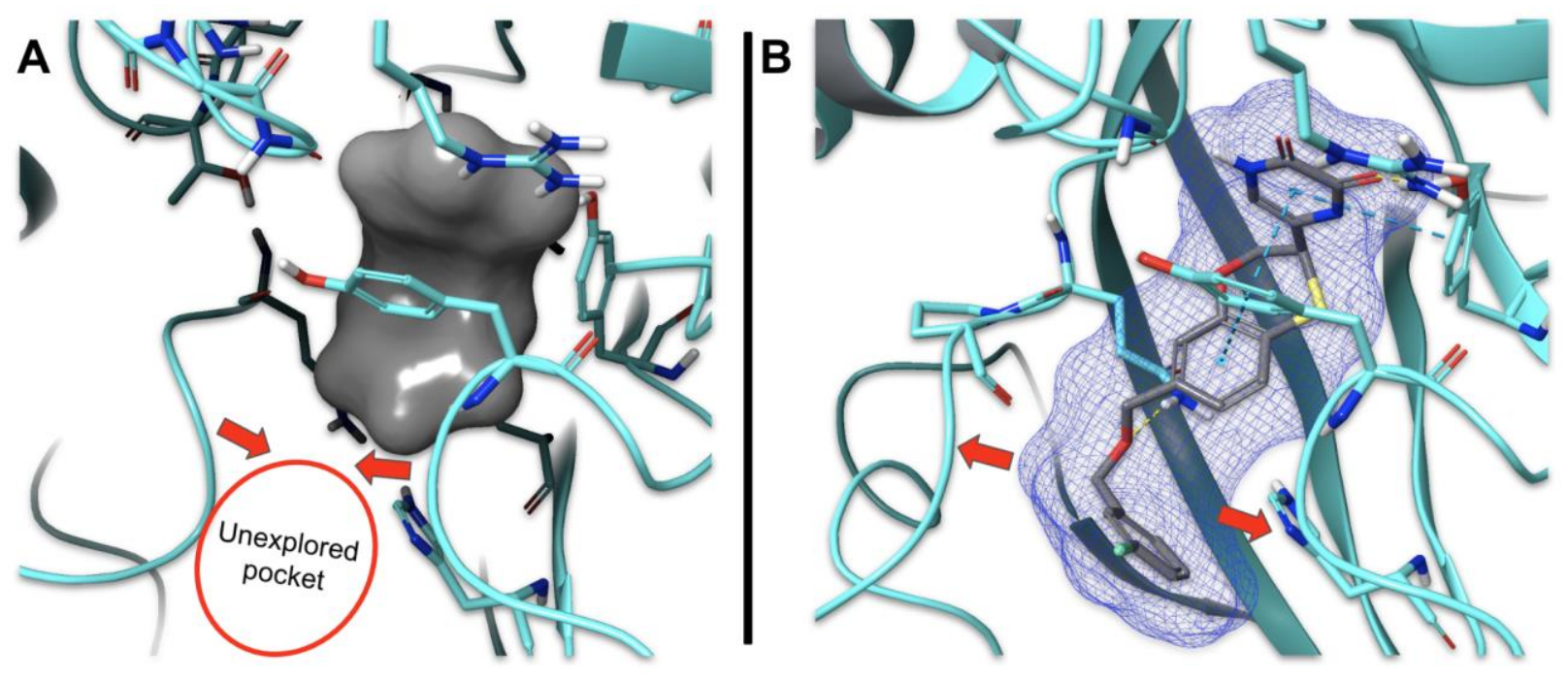


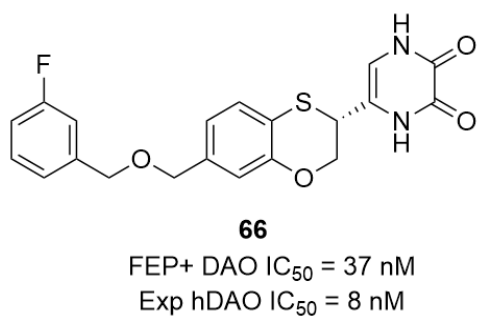

Figure 6. (a) Overlay of publicly disclosed crystallized inhibitors with surface representation (grey). (b) Binding model of compound 66 with novel subpocket outlined in blue.

\section{ADME/PK PROPERTIES}

In order to demonstrate the therapeutic potential of the DHP dione chemical class, the team next tried to identify a suitable candidate to probe PK/PD relationship in vivo. As mentioned earlier in the SAR, most analogs showed moderate permeability and low efflux ratio in the MDCK-MDR1 cell line. They showed excellent stability in the human and mouse liver microsome assay. The compounds have also shown good stability in human and mouse hepatocytes, as no significant turnover was observed for most compounds under the assay conditions employed.

Table 9. In vitro ADME properties of selected compounds.

\begin{tabular}{|c|c|c|}
\hline Compound ID & $\begin{array}{c}\text { LM Clint }(\mathrm{m}) \\
(\mu \mathrm{L} / \mathrm{min} / \mathrm{mg})\end{array}$ & $\begin{array}{c}\text { Hepatocyte Clint } \mathrm{h}(\mathrm{m}) \\
(\mu \mathrm{L} / \mathrm{min} / \mathrm{mil} \text { cells })\end{array}$ \\
\hline $\mathbf{3 6}$ & $<14(<14)$ & $<5(<5)$ \\
\hline $\mathbf{3 7}$ & $<14(<14)$ & $<5(<5)$ \\
\hline $\mathbf{4 2}$ & $<14(<14)$ & $<5(<5)$ \\
\hline $\mathbf{4 6}$ & $<14(<14)$ & $8(10)$ \\
\hline $\mathbf{5 2}$ & $<14(<14)$ & $49(57)$ \\
\hline $\mathbf{5 3}$ & $<14(35)$ & $\mathrm{ND}$ \\
\hline $\mathbf{6 3}$ & $\mathrm{ND}$ & $6(9)$ \\
\hline $\mathbf{6 6}$ & $\mathrm{ND}$ & $16(11)$ \\
\hline
\end{tabular}

The in vivo drug metabolism and pharmacokinetic (DMPK) properties were assessed in cassettes of five compounds each, including $\mathbf{1 7}$ as the reference. Cassette administration is an extremely useful approach to generate in vivo PK data quickly in a cost effective and animal sparing fashion. A cassette dosing strategy also enabled direct comparison of drug brain penetrability among a set of compounds within the same set of animals. In practice, cassette doses were prepared for both intravenous (IV) and oral (PO) administration utilizing a standard dose formulation for each route throughout the project.

Table 10 shows mouse plasma PK of a few compounds in the chemical series. Most analogs showed low to moderate clearance and normal volume of distribution in mice, which resulted in good half-life values. They are also well absorbed when dosed orally with oral bioavailability generally over $40 \%$. Not surprisingly, compound 66 showed reduced and less favorable oral bioavailability, possibly due to multiple rotatable bonds in the structure.

Table 10. Mouse plasma PK of representative compounds

\begin{tabular}{|c|c|c|c|c|c|c|}
\hline Compound ID & $\mathrm{Cl}(\mathrm{mL} / \mathrm{min} / \mathrm{kg})$ & Vdss (L/kg) & $\begin{array}{c}\text { AUCN (iv) } \\
\text { (ng*hr/mL*mg) }\end{array}$ & T1/2 (h) & $\begin{array}{c}\text { AUCN (po) } \\
\text { (ng*hr/mL*mg) }\end{array}$ & $\begin{array}{c}\text { \%F } \\
\text { (ng }\end{array}$ \\
\hline $\mathbf{3 6}$ & 2.7 & 0.5 & 5800 & 2.2 & 2400 & 46 \\
\hline $\mathbf{3 7}$ & 3.0 & 0.6 & 4800 & 2.9 & 3700 \\
\hline
\end{tabular}




\begin{tabular}{|c|c|c|c|c|c|c|}
\hline $\mathbf{4 2}$ & 14 & 1.6 & 1140 & 2.3 & 1300 & 110 \\
\hline $\mathbf{4 6}$ & 17 & 3.6 & 860 & 2.9 & 490 & 57 \\
\hline $\mathbf{5 2}$ & 37 & 1.3 & 440 & 1.3 & 180 & 42 \\
\hline $\mathbf{6 3}$ & 11 & 0.9 & 1390 & 1.5 & 400 & 30 \\
\hline $\mathbf{6 6}$ & 74 & 4.3 & 180 & 1.7 & 26 & 15 \\
\hline
\end{tabular}

The brain PK parameters of the same set of compounds are presented in Table 11. Compared to 17, the DHP dione analogs are generally more brain penetrant, which can be a key advantage. The best analogs achieved Kp,uu around 0.5. Overall, compounds 37, 42 and 46 gave the highest brain drug exposure. Surprisingly, compound 36, a close analog to 37, showed very low brain exposure and Kp, uu despite very nice plasma PK. Disappointingly, both $\mathbf{6 3}$ and 66 showed little to no brain exposure in mice, clearly suggesting that the more potent analogs still require much improvement in $\mathrm{PK} /$ brain penetration.

Table 11. Mouse brain PK of representative compounds

\begin{tabular}{|c|c|c|c|c|c|c|}
\hline Compound ID & $\begin{array}{c}\text { AUCN (iv) } \\
\text { (ng*hr/mL*mg) }\end{array}$ & $\begin{array}{c}\text { AUCN (po) } \\
\text { (ng*hr/mL*mg) }\end{array}$ & \%Fu (plasma) & \%Fu (brain) & Kp (po) & Kp,uu (po) \\
\hline $\mathbf{3 6}$ & 160 & 52 & 8 & 6 & 0.022 & 0.016 \\
\hline $\mathbf{3 7}$ & 820 & 460 & 9 & 5.2 & 0.12 & 0.07 \\
\hline $\mathbf{4 2}$ & 240 & 240 & 17 & 20 & 0.18 & 0.22 \\
\hline $\mathbf{4 6}$ & 200 & 480 & 4 & 2 & 0.98 & 0.54 \\
\hline $\mathbf{5 2}$ & 67 & 38 & 5 & 9 & 0.23 & 0.43 \\
\hline $\mathbf{6 3}$ & 108 & 23 & 7.8 & 2.2 & 0.06 & 0.02 \\
\hline $\mathbf{6 6}$ & 40 & BLQ & 1.1 & 0.4 & 0 & 0 \\
\hline
\end{tabular}

\section{IN VIVO PK/PD MODEL}

Based on compound potency and brain exposure, both 37 and $\mathbf{4 2}$ were considered as potential PK/PD candidates. Compound 46 was deprioritized due to lower free drug fraction in the brain. To enable selection of a PK/PD candidate, high dose oral PK studies were carried out at 10 and $100 \mathrm{mg} / \mathrm{kg}$ for both compounds. Compound 37 demonstrated good dose linearity in brain, while 42 showed sub dose proportionality at $100 \mathrm{mg} / \mathrm{kg}$ (Figure 7). 
A

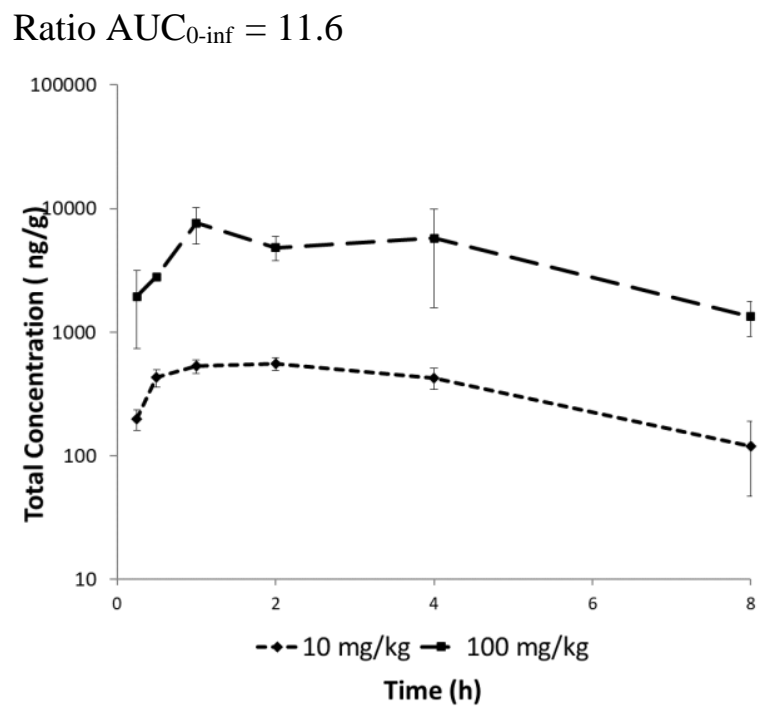

B

Ratio $\mathrm{AUC}_{0 \text {-inf }}=5.2$

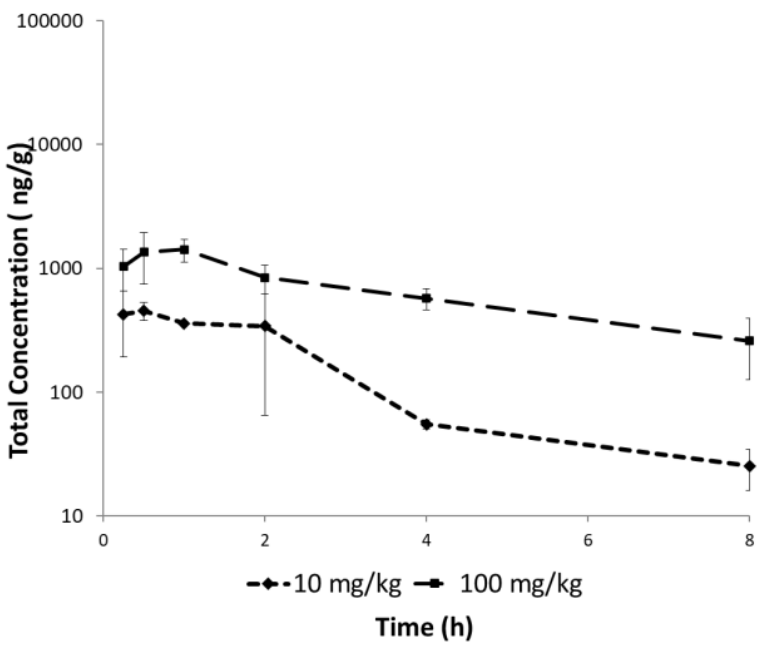

Figure 7. Oral pharmacokinetic profile of compound $37(\mathrm{~A})$ and compound $42(\mathrm{~B})$ in mouse cerebella following administration at 10 and $100 \mathrm{mg} / \mathrm{kg}$

Modeling of the PK and theoretical enzyme occupancy (Equation 1) after a single $100 \mathrm{mg} / \mathrm{kg}$ dose identified $\mathbf{3 7}$ to be the optimal compound to progress into a PK/PD study with a $150 \mathrm{mg} / \mathrm{kg}$ BID, Q4hr dosing regimen. This study design, in conjunction with the measured mouse cell $\mathrm{IC}_{50}$, the concentration of $\mathbf{3 7}$ in the cerebellum and the corresponding free fraction in this tissue was predicted to provide enzyme occupancy and coverage commensurate with an in vivo biomarker response (see Figure 7). Projected tissue concentrations at 15,50 and $150 \mathrm{mg} / \mathrm{kg}$ were calculated following a linear extrapolation of the measured values obtained from the $100 \mathrm{mg} / \mathrm{kg}$ dosing cohort illustrated in Figure 7. These data were used in Equation 1 to generate the \%tEO profiles in Figure 8.

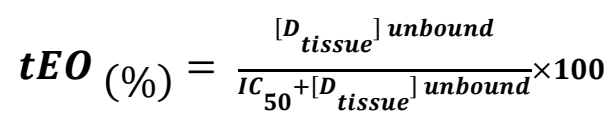

Equation 1. Calculation of theoretical enzyme occupancy (\%tEO) 


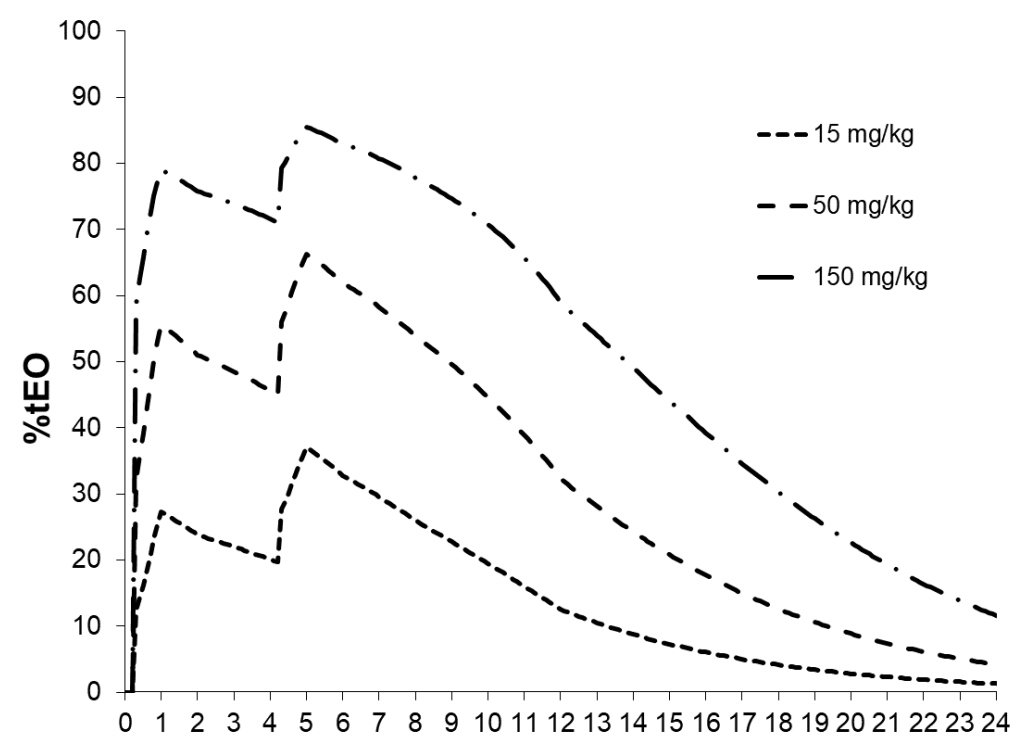

Time (hours)

Figure 8. Projected enzyme occupancy levels following BID Q4hr dosing with compound 37.

Both 37 and $\mathbf{4 2}$ have been extensively screened in vitro for potential off-targets. In the Eurofins Safety/Diversity panel (Table 12), COX2 is the only off-target for both $\mathbf{3 7}$ and $\mathbf{4 2}$, representing about 93 -fold in vitro selectivity for 37 and 132-fold for 42. In addition, the compounds have also been screened against six additional CNS targets at Eurofins, and none of them showed significant activity at $10 \mu \mathrm{M}$ on the six off-targets. No significant inhibition of the major human CYP enzymes ( $<40 \%, 3 \mathrm{~A} 4,2 \mathrm{D} 6,2 \mathrm{C} 9,2 \mathrm{C} 19,2 \mathrm{C} 8,1 \mathrm{~A} 2)$ was observed for either compound at 10 $\mu \mathrm{M}$. In addition, there was a complete absence of any cytotoxicity signal for either compound when they were tested at $100 \mu \mathrm{M}$ in a HepG2 assay that measured 72-hour ATP production and 24-hour Glu/Gal mitotoxicity.

Table 12. Eurofins selectivity data summary

\begin{tabular}{|c|c|c|}
\hline Compound ID & $\mathbf{3 7}$ & $\mathbf{4 2}$ \\
\hline Eurofins Safety/Diversity Panel & COX2 IC 50 & COX2 IC 50 \\
& $9.0 \mu \mathrm{M}(93 \mathrm{x})$ & $9.5 \mu \mathrm{M}(132 \mathrm{x})$ \\
\hline 5-LOX Human Lipoxygenase Enzymatic Assay & $>10 \mu \mathrm{M}$ & $>10 \mu \mathrm{M}$ \\
\hline A3 Human Adenosine GPCR Binding Assay & $>10 \mu \mathrm{M}$ & $>10 \mu \mathrm{M}$ \\
\hline GR Human Glucocorticoid NHR Binding Assay & $>10 \mu \mathrm{M}$ & $>10 \mu \mathrm{M}$ \\
\hline PPAR gamma Human NHR Binding Assay & $>10 \mu \mathrm{M}$ & $>10 \mu \mathrm{M}$ \\
\hline Sigma (Non-Selective) Guinea Pig Binding Assay & $>10 \mu \mathrm{M}$ & $>10 \mu \mathrm{M}$ \\
\hline Sodium Channel, Site 2 & $>10 \mu \mathrm{M}$ & $>10 \mu \mathrm{M}$ \\
\hline CYP Inhibition @ 10 $\mu \mathrm{M}$ & $<40 \%$ & $<40 \%$ \\
\hline HepG2 Glu/Gal & $>100 \mu \mathrm{M}$ & $>100 \mu \mathrm{M}$ \\
\hline HepG2 72-hr ATP & $>100 \mu \mathrm{M}$ & $>100 \mu \mathrm{M}$ \\
\hline
\end{tabular}

Following ethical review and approval of the study protocol, the PK/PD assessment was undertaken to measure the modulation of D-serine levels in the cerebella of mice following administration of the test compound at one dose using the regimen described above. Two cohorts of animals were tested (compound and vehicle) using 33 animals in total ( $\mathrm{n}=8$ /group for $\mathbf{3 7}$ and $\mathrm{n}=3 /$ timepoint for vehicle). In both cases plasma and cerebella samples were collected 
following animal "take-down" at 4-hour, prior to 2nd dosing, 6-hour, and 10-hour after the initial dosing. The levels of D-serine in plasma and brain tissue were quantitatively determined using a chiral LC-MS/MS method, ensuring both adequate sensitivity and selectivity. In addition, CSF was sampled from the animals at the 10-hour timepoint to determine the free, unbound levels of $\mathbf{3 7}$.

The bioanalytical results obtained from the PK/PD study are shown in Figure 9a. As can be seen based on a mouse cell $\mathrm{EC}_{50}$ of $\sim 150 \mathrm{ng} / \mathrm{mL}$ and brain tissue binding of $94.8 \%$, free drug exposures exceeding the mouse cell $\mathrm{EC}_{50}$ were observed at 10 hours in the plasma, cerebellum and CSF. A significant increase of D-serine levels compared to vehicle was also observed in both the plasma and cerebellum at all three time points measured (4, 6 and 10-hour) (Figure 9b).
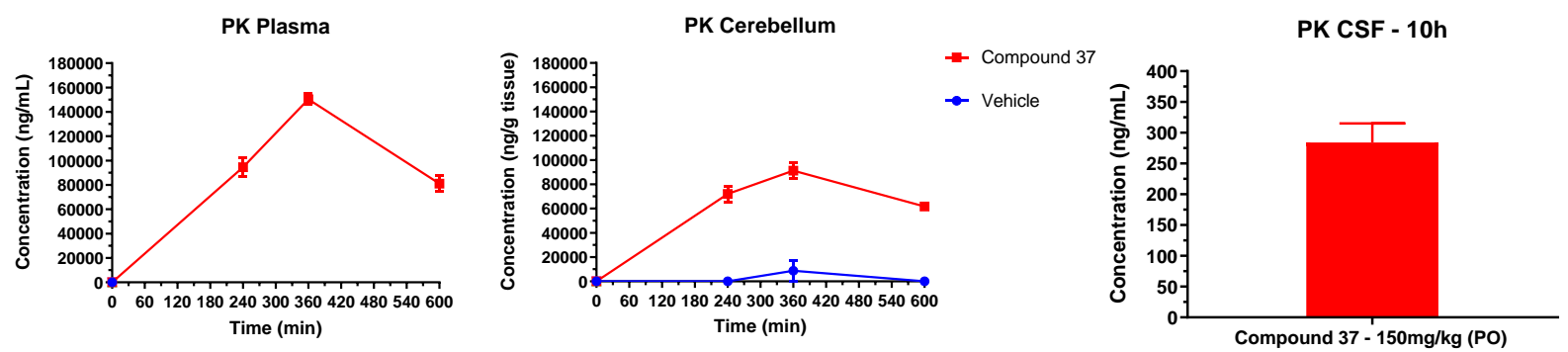

Figure 9a. Bioanalytical data from the PK/PD study
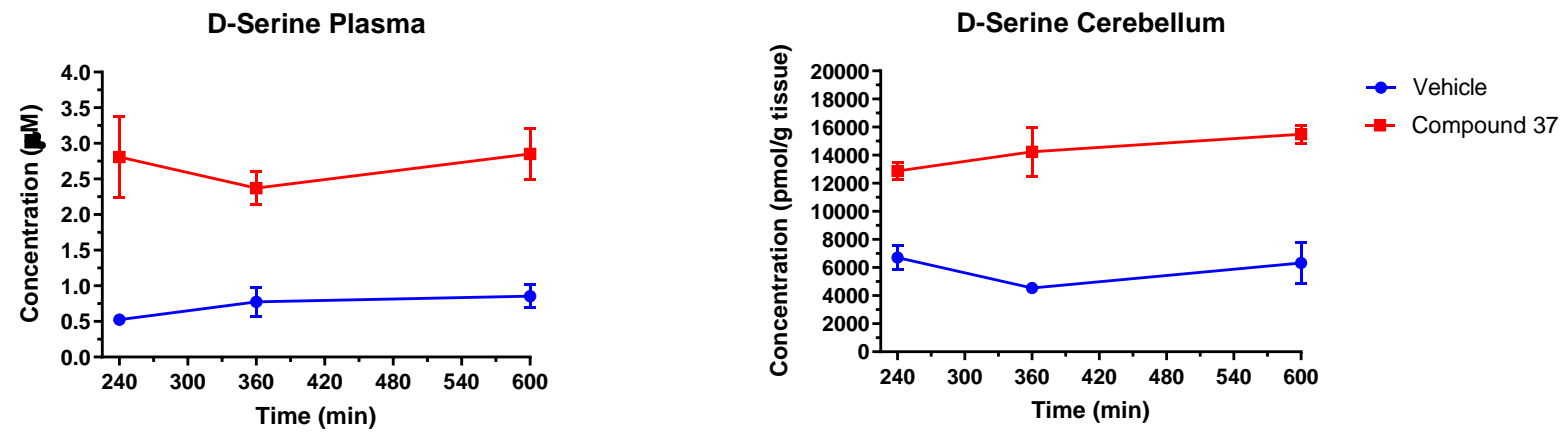

Figure 9b. D-Serine levels in plasma and cerebellum

In addition, a parallel study was run to assess the receptor occupancy (RO) in the cerebellum with the Takeda tracer compound PGM019260 following the protocol published in Neurochemistry Research 2017 (Ref. 18). As shown in Figure 10, the study confirmed significant RO of compound $\mathbf{3 7}$ in the PK/PD study, as projected by PK modeling (Figure 8). 

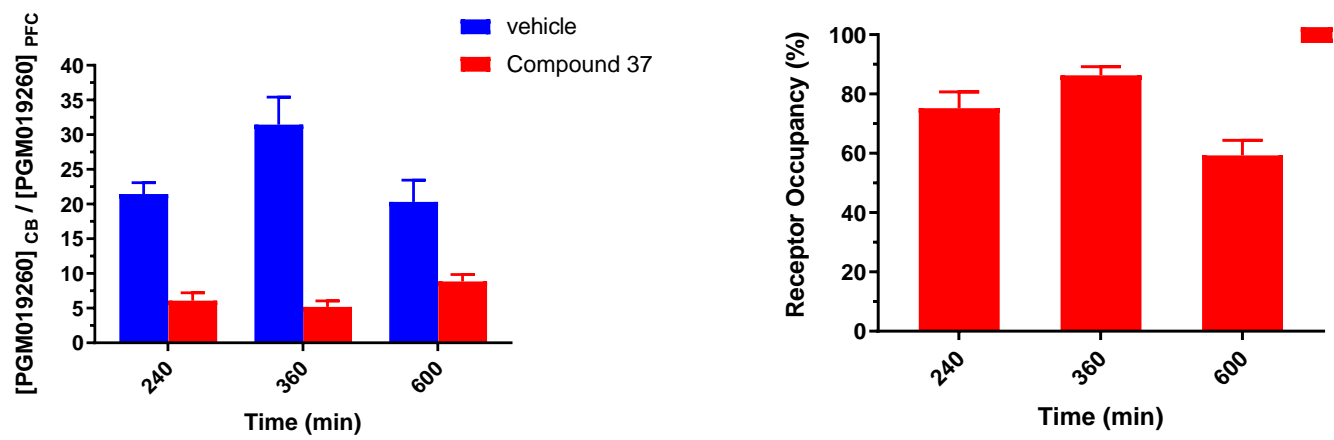

Figure 10. Receptor occupancy of $\mathbf{3 7}$ dose at orally at $150 \mathrm{mg} / \mathrm{kg}$ in the PK/PD study

The results of the PK/PD study are summarized in Table 13. Based upon the data, the PK/PD study with compound 37 has successfully demonstrated the pharmacological potential of hDAO inhibitors from the DHP dione chemical series.

Table 13. Summary of the PK/PD study with compound 37.

\begin{tabular}{|c|c|c|c|c|c|}
\hline \multirow{2}{*}{ Time Points } & \multicolumn{2}{|c|}{ 37 free drug } & Fold increase in D-serine levels & \%RO \\
\cline { 2 - 6 } & Plasma (ng/mL) & Cerebellum (ng/g) & Plasma & Cerebellum & Cerebellum \\
\hline $4 \mathrm{hr}$ & 8505 & 3746 & 5.4 & 1.9 & 75 \\
\hline $6 \mathrm{hr}$ & 13534 & 4750 & 3.1 & 3.1 & 86 \\
\hline $10 \mathrm{hr}$ & 7300 & 3206 & 3.3 & 2.4 & 59 \\
\hline
\end{tabular}

In parallel with the PK/PD study, compound $\mathbf{3 7}$ was also assessed in a catalepsy model using the same dosing regimen (150 mg/kg p.o. BID, Q4hr) that had generated the positive response in the PK/PD study. During this study, plasma samples were taken and used to assess the prolactin levels at 6 hours post the first dose, which was predicted to be around Cmax. As shown in Figure 11, no catalepsy or increase in prolactin levels was observed in this study. Plasma and brain concentrations of $\mathbf{3 7}$ were determined indicating that levels were similar to those achieved in the PK/PD study (data not shown). This study confirms that $\mathbf{3 7}$ is well tolerated in vivo at exposure levels required to evoke the desired PD responses.
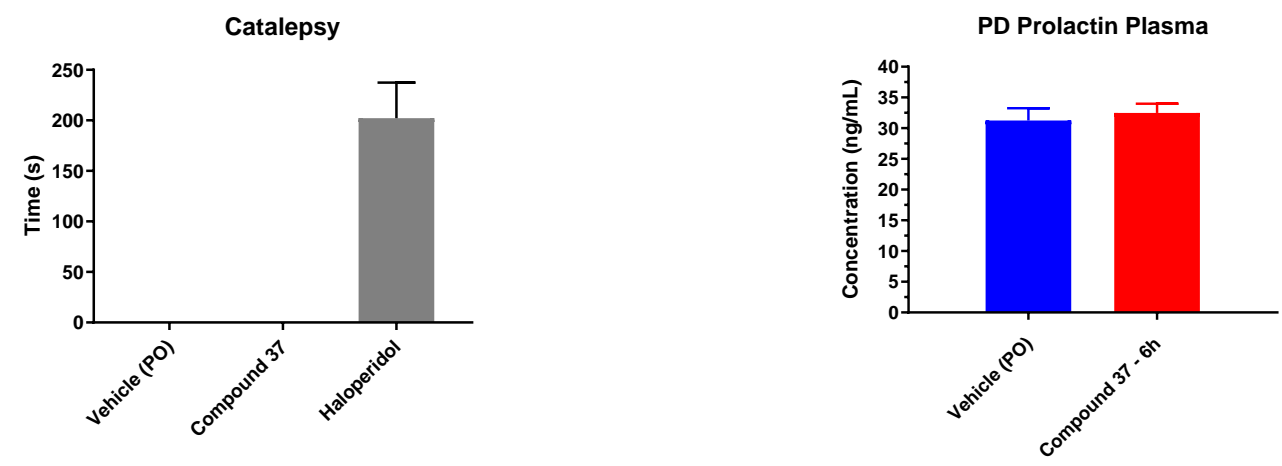
Figure 11. (a) Catalepsy model of 37 dosed orally at $150 \mathrm{mg} / \mathrm{kg} \mathrm{BID,} \mathrm{Q4hr,} \mathrm{(b)} \mathrm{plasma} \mathrm{prolactin} \mathrm{level} \mathrm{with}$ compound 37 dosed orally at $150 \mathrm{mg} / \mathrm{kg}$ BID, Q4hr.

\section{CHEMICAL SYNTHESIS}

Due to the diversity of the SAR, a wide variety of chemistry was attempted to synthesize the compounds on this project. A few typical procedures applied in the syntheses were described below. Please refer to the experimental section for detailed synthesis of the individual analogs.

The synthesis of compound $\mathbf{1 2}$ is illustrated in Scheme A. Treatment of commercial material I-A with 4(trifluoromethyl)styryl boronic acid A-1 under Suzuki-Miyaura cross coupling conditions afforded A-2, which was subsequently reduced to the corresponding alkane $\mathbf{A - 3}$ by catalytic phase-transfer hydrogenation. Finally, compound 12 was obtained by refluxing $\mathbf{A}-3$ in a 1:1 mixture of dioxane and $2 \mathrm{~N}$ aqueous $\mathrm{HCl}$.<smiles>COc1ncc(Br)nc1OC</smiles>

I-A<smiles>OB(O)/C=C/c1ccc(C(F)(F)F)cc1</smiles>

A-1<smiles>COc1ncc(/C=C/c2ccc(C(F)(F)F)cc2)nc1OC</smiles>

A-2<smiles>COc1ncc(CCc2ccc(C(F)(F)F)cc2)nc1OC</smiles>

A-3<smiles>CC(C)(C)C(F)(F)c1ccc(CCc2c[nH]c(=O)c(=O)[nH]2)cc1</smiles>

12

Scheme A. Synthesis of compound 12.

Reaction conditions: (a) $\mathrm{Pd}\left(\mathrm{PPh}_{3}\right)_{4}, \mathrm{Na}_{2} \mathrm{CO}_{3}$, dioxane/ $\mathrm{H}_{2} \mathrm{O}, 95^{\circ} \mathrm{C}$; (b) $\mathrm{Pd}(\mathrm{OH})_{2} / \mathrm{C}$, EtOH reflux; (c) $2 \mathrm{~N} \mathrm{HCl}$, dioxane $100{ }^{\circ} \mathrm{C}$.

Synthesis of the $\alpha$-thioether analogs follows the general procedure in Scheme B, unless otherwise noted. Treatment of B-1 with sodium methanethiosulfone gave rise to B-2, which was reacted with the lithium salt of 2,3dichloropyrazine to afford B-3. Subsequently B-3 was converted to B-4 by reacting with methanol under basic conditions. Finally, hydrolysis of B-4 with $2 \mathrm{~N} \mathrm{HCl}$ produced compound $\mathbf{3 6}$.

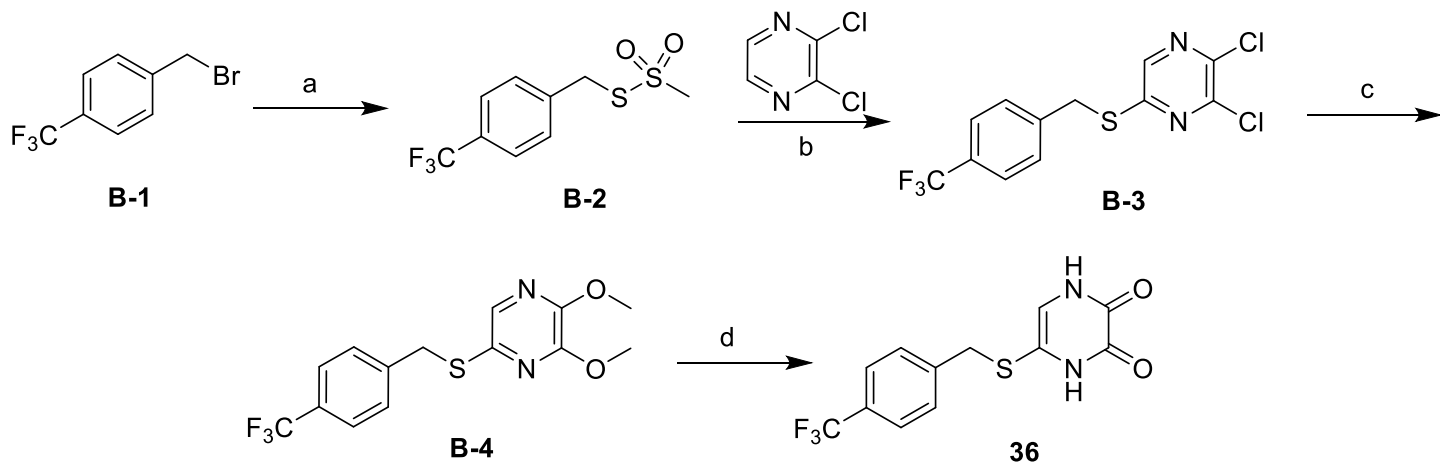

Scheme B. General Procedure for the synthesis of the $\alpha$-thioether compounds. 
Reaction conditions: (a) $\mathrm{NaSSO}_{2}$, DMF, RT; (b) $\mathrm{TMPMgCl} * \mathrm{LiCl}, 0{ }^{\circ} \mathrm{C}$; (c) $\mathrm{NaH}, \mathrm{MeOH}, \mathrm{RT}$; (d) $2 \mathrm{~N} \mathrm{HCl}$, dioxane, $100{ }^{\circ} \mathrm{C}$.

Scheme $\mathrm{C}$ describes the synthesis of compound 37. Treatment of I-A with $n$-butyllithium and subsequent quenching with $N, N$-dimethylformamide yielded 5,6-dimethoxypyrazine-2-carbaldehyde $\mathbf{C - 1}$. Reduction of $\mathbf{C}-\mathbf{1}$ with sodium borohydride and bromination of the resulting alcohol C-2 using Appel conditions generated key bromide intermediate $\mathbf{C - 3}$ which has been prepared using this route on multi-gram scale. Treatment of $\mathbf{C - 3}$ with 4(trifluoromethyl)benzenethiol C-4 in $N, N$-dimethylformamide with cesium carbonate and cesium fluoride afforded 2,3-dimethoxy-5-(((4-(trifluoromethyl)phenyl)thio)methyl)pyrazine C-5. Finally refluxing $\mathbf{C}-5$ with $2 \mathrm{~N} \mathrm{HCl}$ in dioxane afforded compound 37.

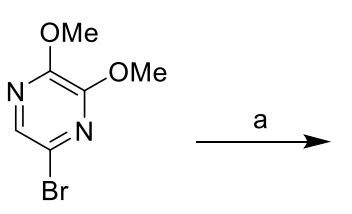

I-A

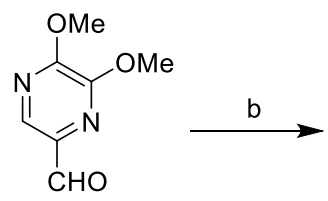

C-1<smiles>COc1ncc(CO)nc1OC</smiles>

C-2

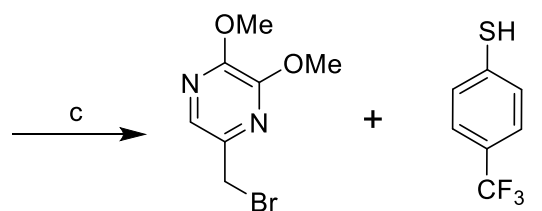

C-3
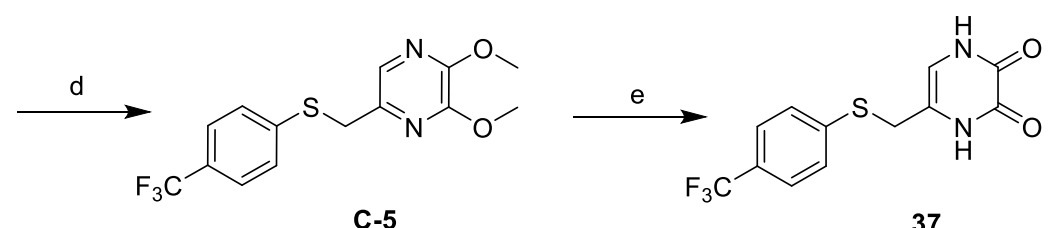

Scheme C. Synthesis of compound 37.

Reaction conditions: (a) n-BuLi, THF, $-78^{\circ} \mathrm{C}$, then DMF; (b) $\mathrm{NaBH}_{4}, \mathrm{MeOH}, 0{ }^{\circ} \mathrm{C}$; (c) $\mathrm{CBr}_{4}, \mathrm{PPh}_{3}$; (d) $\mathrm{Cs}_{2} \mathrm{CO}_{3}$, CsF, DMF, $50{ }^{\circ} \mathrm{C}$; (e) $2 \mathrm{~N} \mathrm{HCl}$, dioxane, $100^{\circ} \mathrm{C}$.

Synthesis of fused-ring analogs follows the general procedure in Scheme D, unless otherwise noted. Starting from commercial I-A, coupling to potassium vinyltrifluoroborate produced alkene D-1. Treatment of D-1 with AD mix- $\alpha$ gave rise to the corresponding chiral diol asymmetrically, which was converted to the silyl ether D-2 subsequently. Reacting D-2 with thiol I-B furnished thiol ether D-3, which was treated under palladium catalyzed conditions to afford the cyclized ether D-4. Final hydrolysis of the methoxy groups under acidic conditions yielded fuse-ring analog D-5.

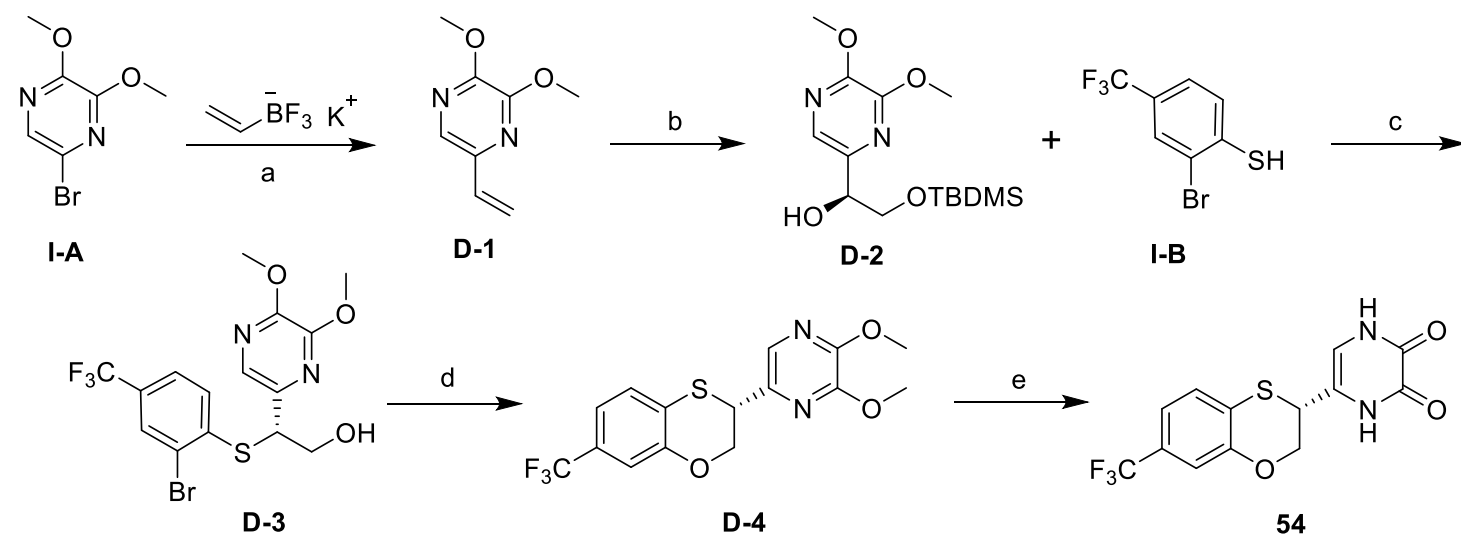

Scheme D. General procedure for the fuse-ring analogs.

Reaction conditions: (a) Pd(dppf)Cl 2 DCM complex; (b) (1) AD Mix- $\alpha$; (2) TBDMS-Cl; (c) (1) DIAD, $\mathrm{PPh}_{3}$; (2) TBAF; (d) $\mathrm{Pd}(\mathrm{OAc})_{2}$, TrixiePhos, $\mathrm{Cs}_{2} \mathrm{CO}_{3}$; (2) $2 \mathrm{~N} \mathrm{HCl}$, dioxane, $100{ }^{\circ} \mathrm{C}$. 
Palladium catalyzed coupling of I-A to 2-Isopropenyl-4,4,5,5-tetramethyl-1,3,2-dioxaborolane gave rise to E-1, which was treated with NBS and $\mathrm{NaOH}$ to produce epoxide E-2. Reacting E-2 to thiol I-B under activation by InCl3 furnished thiol ether $\mathbf{E - 3}$, which was subsequently converted to the cyclized ether $\mathbf{E}-\mathbf{4}$ with palladium catalysis. Final hydrolysis of E-4 under acidic conditions followed by chiral resolution yielded the quaternary methyl compound 62.<smiles>COc1ncc(Br)nc1OC</smiles>

I-A
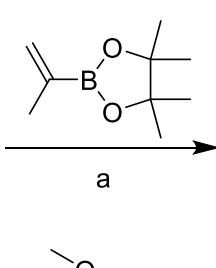<smiles>COc1ncc(C(C)(CO)Sc2ccc(C(F)(F)F)cc2Br)nc1OC</smiles><smiles>C=C(C)c1cnc(OC)c(OC)n1</smiles>

E-1

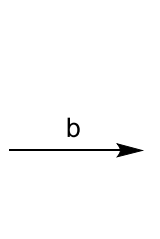

$\overbrace{\mathrm{O}}^{\mathrm{N}} \mathrm{T}_{\mathrm{E}-2}^{\mathrm{N}}$

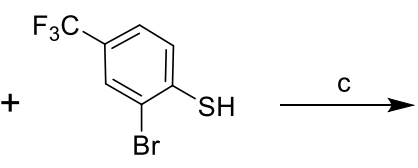

I-B

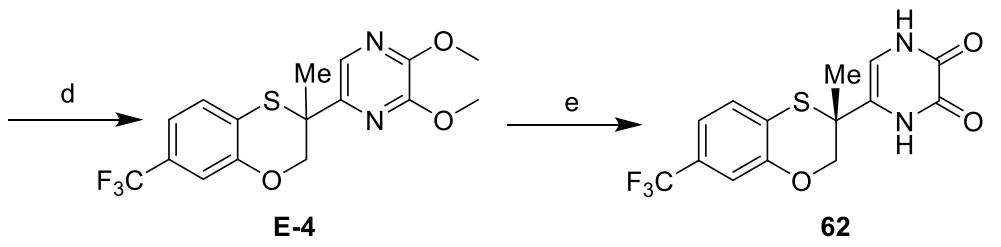

Scheme E. Synthesis of the quaternary methyl analogs.

Reaction conditions: (a) $\mathrm{Pd}\left(\mathrm{PPh}_{3}\right)_{4}$; (b) NBS, NaOH ; (c) I-B, $\mathrm{InCl}_{3}$; (d) $\mathrm{Pd}(\mathrm{OAc})_{2}$, TrixiePhos, $\mathrm{Cs}_{2} \mathrm{CO}_{3}$; (e) $2 \mathrm{~N} \mathrm{HCl}$, dioxane, $100{ }^{\circ} \mathrm{C}$.

\section{CONCLUSIONS}

In summary, we have discovered a novel class of small molecule inhibitors against the human D-amino Acid Oxidase (DAO). Different from the earlier lead compounds, this chemical class features a non-acidic dihydropyrazine dione head moiety. Starting from hit compound 12, SAR work in the linker region led to the discovery of thioether linker analogs which showed enhanced DAO potency with desirable PK and brain penetration properties. With tool compound 37, we were able to demonstrate PK/PD in an in vivo mouse model at drug exposure levels devoid of any adverse events. Continued SAR work has led to compounds with significant improvement in both DAO biochemical and cellular potency.

We have leveraged Schrödinger's computational modeling technology extensively to accelerate the program execution. Free energy perturbation (FEP+) technology was applied to prioritize compounds based on prospective binding potency predictions. Overall, the FEP+ models have performed well in predicting compounds binding potency to the hDAO enzyme. As shown in Figure 12, compound experimental hDAO inhibitory potency correlates well with prospectively predicted potency across the three chemical series. ${ }^{24}$ Of the $\sim 11000$ ideas designed and profiled in silico, we synthesized 208 compounds and only 20 of these were unexpectedly inactive (>10 uM), demonstrating that the physics-based methods allowed us to quickly prioritize compounds of interest and deprioritize compounds that did not meet project objectives. In addition to structure-based design by seasoned medicinal chemists and modelers, we have also applied computational enumeration with our AutoDesigner algorithm to generate novel design ideas. Most notably, this effort has helped to identify a novel subpocket for further SAR development on the project. As is common for CNS programs, the challenge is to balance compound potency with desirable PK/brain penetration properties. While a working model to predict PK/brain penetration has been elusive on this project, we will continue to apply the Schrödinger computational modeling technology along with drug-likeness and CNS MPO filters to prioritize compounds for synthesis. Further optimization work toward a development candidate will be reported in due course. 


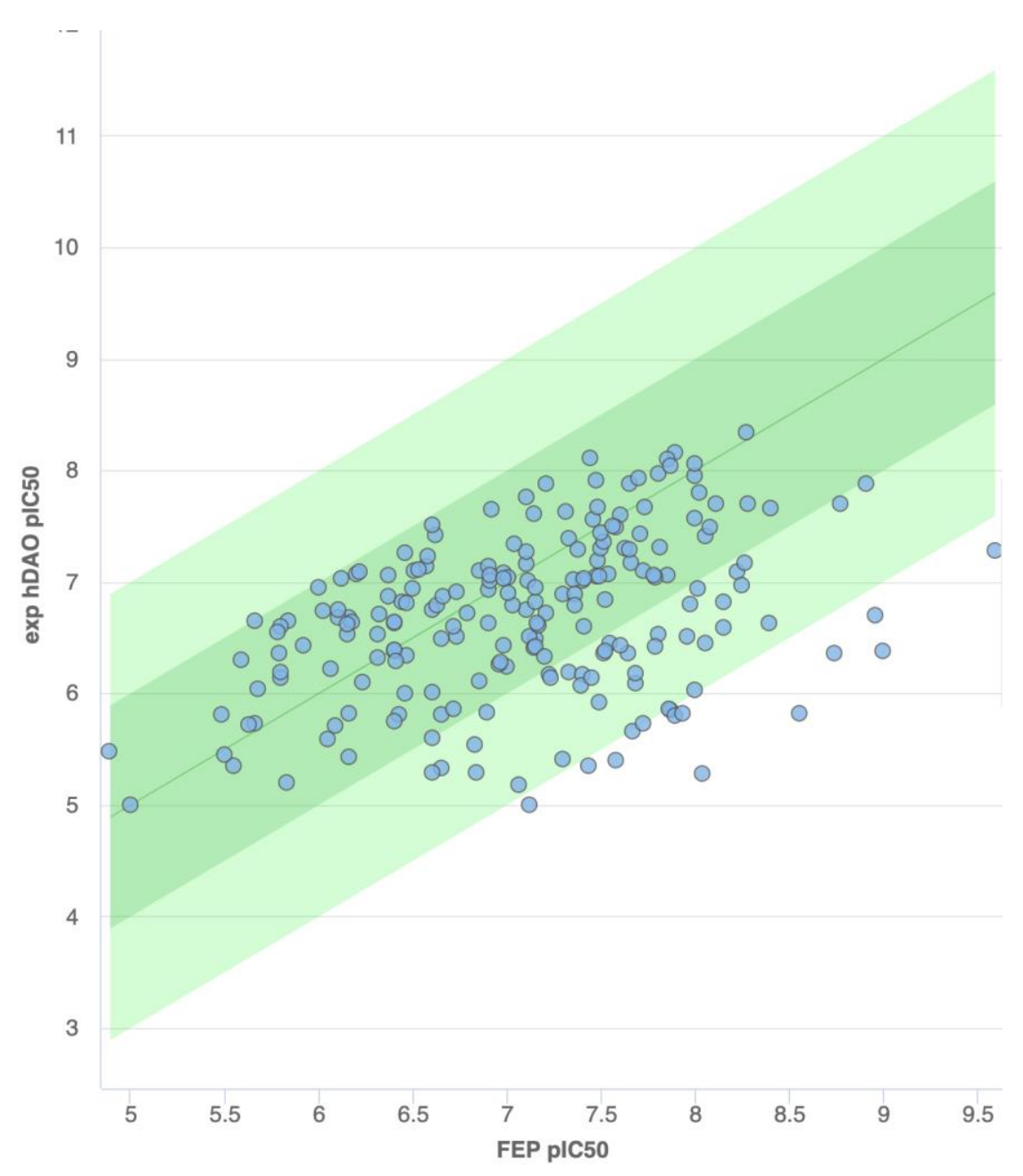

Figure 12. FEP+ prospective performance. Mean Unsigned Error $=0.71$

\section{EXPERIMENTAL SECTION}

\section{In vitro assay protocols}

The D-amino acid oxidase (DAO) assays are fluorescence-based assays, in which the hydrogen peroxide $\left(\mathrm{H}_{2} \mathrm{O}_{2}\right)$ generated from the reaction of D-serine with DAO and Flavine Adenine Dinucleotide (FAD), is linked to oxidation of Amplex Red in the presence of horseradish peroxidase (HRP). The Amplex Red reagent reacts with $\mathrm{H}_{2} \mathrm{O}_{2}$ in a 1:1 stoichiometry to produce the red-fluorescent oxidation product, resorufin, which is measured fluorometrically.

\section{Preparation of Assay Ready Plates}

100-fold concentrated, 12-point serial dilutions of test compounds ( $250 \mathrm{~nL})$ in duplicate were prepared using DMSO in 384 well black plates (262260, Nunc) using the Echo555 Acoustic Dispenser (Labcyte). These assay ready plates were employed in the biochemical and cellular screening assays described below.

Human DAO Biochemical Assay 
The human DAO biochemical assay was performed using reagents at the following final assay concentrations: $1 \mathrm{nM}$ recombinant full-length human DAO protein, D-Serine at Km concentration $(10 \mathrm{mM}), 50 \mu \mathrm{M}$ FAD (excess), $50 \mu \mathrm{M}$ Amplex Red and $0.1 \mathrm{U} / \mathrm{mL}$ HRP in the presence of compound or DMSO vehicle (1\%). All reagents were made up in assay buffer containing $20 \mathrm{mM}$ Tris, $\mathrm{pH} 7.4+0.1 \%$ BSA. The final assay volume was $25 \mu \mathrm{L} / \mathrm{well}$.

Briefly, $10 \mu \mathrm{L}$ of a working solution containing $2.5 \mathrm{nM}$ hDAO (TECC-1280-14AA, Takeda) and $125 \mu \mathrm{M}$ FAD (F6625, Sigma) in assay buffer was added to all the wells in the assay ready plate (containing $250 \mathrm{~nL}$ compound / DMSO vehicle per well) except for the negative control wells. $10 \mu \mathrm{L}$ of $125 \mu \mathrm{M}$ FAD (working solution) was added to the negative control wells containing $250 \mathrm{~nL}$ of DMSO vehicle. The plates were incubated at $25^{\circ} \mathrm{C}$ for 20 minutes (pre-incubation of compound with human DAO).

$10 \mu \mathrm{L}$ of a working solution containing $125 \mu \mathrm{M}$ Amplex Red and $0.25 \mathrm{U} / \mathrm{mL}$ HRP (A22188, ThermoFisher Scientific) in assay buffer was then added to all the wells. The reaction was initiated by the addition of $5 \mu \mathrm{L}$ of $50 \mathrm{mM}$ D-Serine (S4250, Sigma-Aldrich) to all the wells. The plate was incubated for 4 hours in the dark at $25^{\circ} \mathrm{C}$ before measuring fluorescence in each well using the Envision plate reader with excitation at $530 \mathrm{~nm}$ and emission at $595 \mathrm{~nm}$.

Concentration response curves were generated using ActivityBase (IDBS). IC $_{50}$ values were determined by plotting $\%$ Inhibition vs Log10 compound concentration using a sigmoidal fit with a variable slope (four parameter fit).

\section{Horseradish Peroxidase (HRP) Counter Screen}

The HRP counter screen was routinely performed using reagents at the following final assay concentrations: D-Serine $(10 \mathrm{mM}), \mathrm{FAD}(50 \mu \mathrm{M})$, Amplex Red $(50 \mu \mathrm{M}), \mathrm{HRP}(0.1 \mathrm{U} / \mathrm{mL})$ and hydrogen peroxide $\left(\mathrm{H}_{2} \mathrm{O}_{2}\right)(2 \mu \mathrm{M})$ in the presence of compound or DMSO vehicle (1\%). All reagents were made up in assay buffer containing $20 \mathrm{mM}$ Tris, $\mathrm{pH} 7.4+$ $0.1 \%$ BSA. The final assay volume was $25 \mu \mathrm{L} /$ well.

Briefly, $5 \mu \mathrm{L}$ of $250 \mu \mathrm{M} \mathrm{FAD}$ and $5 \mu \mathrm{l}$ of $50 \mathrm{mM}$ D-Serine were added to all the wells in the assay ready plate (containing $250 \mathrm{~nL}$ compound / DMSO vehicle per well). $5 \mu \mathrm{L}$ of a working solution containing $250 \mu \mathrm{M}$ Amplex Red and $0.5 \mathrm{U} / \mathrm{mL} \mathrm{HRP}$ was added to all the wells except for the negative control wells. $5 \mu \mathrm{L}$ of $250 \mu \mathrm{M}$ Amplex Red was added to the negative control wells containing $250 \mathrm{~nL}$ of DMSO vehicle. $10 \mu \mathrm{L}$ of $5 \mu \mathrm{M} \mathrm{H}_{2} \mathrm{O}_{2}$ was added to all the wells. The plate was incubated for 10 minutes in the dark at $25^{\circ} \mathrm{C}$ before measuring fluorescence in each well using the Envision plate reader with excitation at $530 \mathrm{~nm}$ and emission at $595 \mathrm{~nm}$.

Dose response curves were generated using ActivityBase (IDBS). $\mathrm{IC}_{50}$ values were determined by plotting $\%$ Inhibition vs $\log 10$ compound concentration using a sigmoidal fit with a variable slope (four parameter fit).

\section{Human DAO Cell Assay}

The human DAO cell assay routinely employed a CHO-K1 clone, which was stably transfected with a mammalian expression plasmid containing the human DAO nucleotide encoding the full-length human DAO protein. This cell line was originally generated as described in Howley et al, 2017 (Supplementary Information). The human DAO CHO-K1 stable cell line was routinely cultured in Gibco Ham's F-12 Nutrient Mix (31765-027, ThermoFisher Scientific) containing 10\% FBS (10082-147, ThermoFisher Scientific) and $500 \mu \mathrm{g} / \mathrm{mL}$ Geneticin ${ }^{\mathrm{TM}}$ Selective Antibiotic (10131-027, ThermoFisher Scientific).

The human DAO cell assay was performed using the following final assay conditions: 25,000 human DAO CHO-K1 stable cells/well, $50 \mathrm{mM}$ D-Serine, $50 \mu \mathrm{M}$ Amplex Red and $0.125 \mathrm{U} / \mathrm{mL}$ HRP. All cells and reagents were made up in $10 \mathrm{mM}$ HEPES buffer (15630-056, ThermoFisher Scientific). The final assay volume was $25 \mu \mathrm{L} / \mathrm{well}$.

The human DAO CHO-K1 stable cells were trypsinised, resuspended in complete medium and centrifuged at 1200 rpm for 4 minutes at room temperature. The cell pellet was then washed in $10 \mathrm{mM}$ HEPES buffer and centrifuged at 
$1200 \mathrm{rpm}$ for 4 minutes at room temperature. The resulting cell pellet was resuspended in $10 \mathrm{mM}$ HEPES buffer at $1.25 \times 10^{6} \mathrm{cells} / \mathrm{mL}$.

25,000 human DAO CHO-K1 stable cells (20 $\mu \mathrm{L}$ in $10 \mathrm{mM}$ HEPES buffer) were added to all the wells in the assay ready plate (containing $250 \mathrm{~nL}$ compound / DMSO vehicle per well). $5 \mu 1$ of a working solution containing $250 \mathrm{mM}$ D-Serine, $250 \mu \mathrm{M}$ Amplex Red and $0.625 \mathrm{U} / \mathrm{mL}$ HRP in assay buffer was added to all the wells except for the negative control wells. $5 \mu \mathrm{L}$ of a working solution of $250 \mu \mathrm{M}$ Amplex Red and $0.625 \mathrm{U} / \mathrm{mL}$ HRP in assay buffer was added to the negative control wells. The plate was incubated for 30 minutes in the dark at $25^{\circ} \mathrm{C}$ before measuring fluorescence in each well using the Envision plate reader with excitation at $530 \mathrm{~nm}$ and emission at $595 \mathrm{~nm}$.

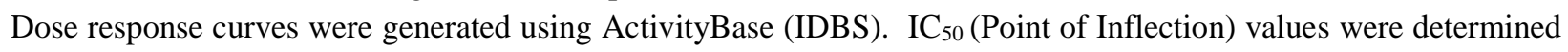
by plotting \% Inhibition vs Log 10 compound concentration using a sigmoidal fit with a variable slope (four parameter fit).

\section{Mouse DAO Cell Assay}

The mouse DAO cell assay routinely employed CHO-K1 cells, which were transiently transfected with an expression plasmid containing the mouse DAO nucleotide encoding the full-length mouse DAO protein. The CHO-K1 cell line was routinely cultured in Gibco Ham's F-12 Nutrient Mix containing 10\% FBS.

The mouse DAO cell assay was performed using the following final assay conditions: 35,000 CHO-K1 cells transiently transfected with mouse DAO/ pcDNA3.1+C_(K)-DYK expression plasmid, $50 \mathrm{mM}$ D-Serine, $50 \mu \mathrm{M}$ Amplex Red and $0.125 \mathrm{U} / \mathrm{mL}$ HRP. All cells and reagents were made up in $10 \mathrm{mM}$ HEPES buffer. The final assay volume was $25 \mu \mathrm{L} /$ well.

Briefly, 5x10 $0^{6} \mathrm{CH}-\mathrm{K} 1$ cells were seeded into two T175 flasks, in Gibco Ham's F-12 Nutrient Mix containing 10\% FBS and incubated for 24 hours at $37^{\circ} \mathrm{C} / 5 \% \mathrm{CO}_{2}$.

The T175 flasks, which were seeded with CHO-K1 cells were transfected with mouse DAO/ pcDNA3.1+C_(K)-DYK expression plasmid as follows. A transfection mix for each T175 flask was made up containing $43.75 \mu \mathrm{L}$ mouse DAO/ pcDNA3.1+C_(K)-DYK expression plasmid (OMu05394D_pcDNA3.1+ C_(K)-DYK endotoxin free (maxiprep, $1 \mathrm{mg} / \mathrm{mL}$, Genscript), $8575 \mu \mathrm{L}$ of Optimem (31985-062, ThermoFisher Scientific) and $131.25 \mu \mathrm{L}$ of Lipofectamine LTX (15338-100, ThermoFisher Scientific). The transfection mix was incubated at room temperature for 25 minutes. During this incubation period the complete growth medium was removed by aspiration from the CHO-K1 cells, which were seeded 24 hours previously and replaced with $35 \mathrm{ml}$ of fresh Gibco Ham's F-12 Nutrient Mix containing $10 \%$ FBS. The transfection mix was then added to each flask containing CHO-K1 cells and incubated for a further 24 hours at $37^{\circ} \mathrm{C} / 5 \% \mathrm{CO}_{2}$.

The mouse DAO transiently transfected CHO-K1 cells were trypsinised, resuspended in complete medium and centrifuged at $1200 \mathrm{rpm}$ for 4 minutes at room temperature. The cell pellet was then washed in $10 \mathrm{mM}$ HEPES buffer and centrifuged at $1200 \mathrm{rpm}$ for 4 minutes at room temperature. The resulting cell pellet was resuspended in $10 \mathrm{mM}$ HEPES buffer at $1.75 \times 10^{6} \mathrm{cells} / \mathrm{mL}$.

35,000 mouse DAO CHO-K1 transiently transfected cells ( $20 \mu \mathrm{L}$ in $10 \mathrm{mM}$ HEPES buffer) were added to all the wells in the assay ready plate (containing $250 \mathrm{~nL}$ compound / DMSO vehicle per well). $5 \mu \mathrm{L}$ of a working solution containing $250 \mathrm{mM}$ D-Serine, $250 \mu \mathrm{M}$ Amplex Red and $0.625 \mathrm{U} / \mathrm{mL}$ HRP in assay buffer was added to all the wells except for the negative control wells. $5 \mu \mathrm{L}$ of a working solution of $250 \mu \mathrm{M}$ Amplex Red and $0.625 \mathrm{U} / \mathrm{mL} \mathrm{HRP}$ in assay buffer was added to the negative control wells. The plate was incubated for 30 minutes in the dark at $25^{\circ} \mathrm{C}$ before measuring fluorescence in each well using the Envision plate reader with excitation at $530 \mathrm{~nm}$ and emission at $595 \mathrm{~nm}$. 
Dose response curves were generated using ActivityBase (IDBS). IC $_{50}$ (Point of Inflection) values were determined by plotting \% Inhibition vs Log 10 compound concentration using a sigmoidal fit with a variable slope (four parameter fit).

\section{Mouse pharmacokinetics}

Male C57B1/6NCrl mice, Inbred, SPF-Quality, Charles River, Germany between 8 and 10 weeks of age, ranging from 20 to 40 grams were used to study the pharmacokinetics of test compounds. On arrival and following randomization animals were housed individually in polycarbonate cages equipped with water bottles, unless contraindicated by study procedures (such as pharmacokinetic blood sampling) or clinical signs. Pelleted rodent diet (SM R/M-Z from SSNIFF® Spezialdiäten GmbH, Soest, Germany) was provided ad libitum throughout the study, except during designated procedures. The compounds were administered to the mice via a single intravenous (slow bolus) injection to the tail vein using a vehicle comprising DMSO, PEG200 and Water. Terminal blood samples were collected via aorta puncture following inhalation anaesthesia into K2EDTA tubes and stored on wet ice. Oral cohorts were dosed by gavage using a vehicle of $0.5 \%(\mathrm{w} / \mathrm{v})$ methylcellulose and $0.1 \%(\mathrm{v} / \mathrm{v})$ Tween 80 in water with bloods collected using a similar procedure. Whole blood was processed to plasma by centrifugation (3000g for 10 minutes at $5^{\circ} \mathrm{C}$ ) within 30 minutes of collection. Plasma samples were transferred into 96 well plates (matrix tubes) and stored at $<-75^{\circ} \mathrm{C}$. Following termination, brains were collected from the animals and the cerebella separated. Both tissues were rinsed with saline, weighed and stored at $\leq-75 \mathrm{oC}$ prior to analysis using LC-MS-MS.

Plasma and brain samples were extracted by protein precipitation using acetonitrile containing an appropriate internal standard. Specific reaction monitoring transitions were identified using automated instrumental optimization procedures for each compound studied, to ensure adequate linearity of response and define the upper and lower limits of quantitation. Samples were injected (SIL-30AC Autosampler, Schimadzu, Kyoto, Japan) onto a reverse phase chromatography system (A: $0.1 \%$ formic acid in ultrapure water; B: $0.1 \%$ formic acid in acetonitrile, Waters Corporation Acquity ${ }^{\circledR}$ UPLC column HSS T3 1.8 $\mu$ ). Analysis was performed using an API 5000 triple quadrupole mass spectrometer fitted with an electrospray ionisation source (AB Sciex, Ontario, ON, Canada). Pharmacokinetic analysis was performed with IDBS E-WorkBook v10 using mean data, non-compartmental analysis and the nominal dose of test item administered to the study animals.

\section{Hepatic microsomal stability}

The stability of the test compounds $(1 \mu \mathrm{M})$ was measured following incubation at $37^{\circ} \mathrm{C}$ with hepatic microsomes $(0.5 \mathrm{mg}$ protein $/ \mathrm{mL}$ for all species) in the presence of the cofactor, NADPH. Incubates were prepared in duplicate, with aliquots removed at 0,5,10,20 and 40 minutes and reactions terminated and compound extracted by the addition of acetonitrile containing an analytical internal standard. The disappearance of parent compound was monitored by LC-MS/MS and the half-life determined over the time-course of incubation. The half-life values were used to calculate their in vitro intrinsic clearance expressed as $\mu \mathrm{L} / \mathrm{min} / \mathrm{mg}$ protein.

\section{Cryopreserved hepatocyte stability}

The stability of test compounds $(1 \mu \mathrm{M})$ were measured following incubation at $37^{\circ} \mathrm{C}$ with cryopreserved hepatocytes in suspension at a cell density of 0.5 million cells per $\mathrm{mL}$. Incubates were prepared in duplicate with aliquots removed at seven time points over a period of 120 minutes and reactions terminated and compound extracted by the addition of acetonitrile containing an analytical internal standard. The disappearance of the parent compounds were monitored by LC-MS/MS and half-life values determined over the course of the incubation. The half-life values obtained were used to calculate their in vitro intrinsic clearance expressed as $\mu \mathrm{L} / \mathrm{min} /$ million cells. 


\section{MDCK assay protocol}

MDR1-MDCK cells were seeded into 24 well Transwell plates and cultured for 3 days to form monolayers. The test compounds were prepared at $10 \mu \mathrm{M}$ in Hanks' Balanced Salt Solution containing $25 \mathrm{mM}$ HEPES and loaded into the donor compartments of Transwell plates bearing the cell monolayers ( $\mathrm{pH} 7.4$ for both donor and receiver compartments). Lucifer Yellow was added to the apical buffer in all wells to assess integrity of the cell monolayer. Duplicate wells were prepared and incubated at $37^{\circ} \mathrm{C}$ in a $\mathrm{CO} 2$ incubator. Samples were removed at time zero and 60 minutes and test compound analysed by LC-MS/MS. Concentrations of Lucifer Yellow in the samples were measured using a fluorescence plate reader. The apparent permeability (Papp) values of test compound were determined for both the apical to basal $(\mathrm{A}>\mathrm{B})$ and basal to apical $(\mathrm{B}>\mathrm{A})$ permeation and the efflux ratio $(\mathrm{B}>\mathrm{A}$ : $\mathrm{A}>\mathrm{B})$ determined.

\section{Animal Models}

In vivo studies were performed at Charles River Laboratories (South San Francisco, CA, USA) under animal welfare protocols approved by the Institutional Animal Care and Use Committee of Charles River Laboratories, South San Francisco, and they adhere to the ACS Ethical Guidelines for animal studies.

In the PK/PD study, adult male C57Bl/6 mice with 7-8 weeks of age were dosed orally with compound $\mathbf{3 7}$ as a suspension in $1 \%$ Tween 80 in $0.5 \%$ methylcellulose at $150 \mathrm{mg} / \mathrm{kg}$ BID q4h. Terminal tissue collection was conducted at 4, 6, and 10 hours after treatment (11 mice/timepoint). Mice being euthanized for the 4-hour group were euthanized before $2 \mathrm{nd}$ dosing. At each collection timepoint, mice were euthanized by $\mathrm{CO}_{2}$ asphyxiation and blood was collected via cardiac puncture into vials containing $\mathrm{K}^{+}$EDTA anticoagulant. Then, brains were extracted, and cerebellum dissected, separated into 2 equal parts then placed into pre-weighed $1.5 \mathrm{ml}$ tubes. Terminal CSF was collected for $10 \mathrm{~h}$ treatment group only. Upon collection, all tissue samples and CSF were weighed, snap frozen in liquid nitrogen and stored at $-80{ }^{\circ} \mathrm{C}$ for analysis.

The receptor occupancy study followed very similar protocol as the PK/PD study. In addition to treatment group with compound 37 and the vehicle group, a third group of C57Bl/6 mice $(\mathrm{n}=12,4$ at each timepoint) were dosed IV with tracer compound PGM019260 at $60 \mu \mathrm{g} / \mathrm{kg}$ in $10 \%$ DMSO in $0.5 \% 90 \% \mathrm{HP}-\beta-\mathrm{CD}, 20$ minutes prior to the defined takedown time. Terminal tissue collection was conducted at 4,6 , and 10 hours after treatment (14 mice/timepoint). At each collection timepoint, mice were euthanized by $\mathrm{CO}_{2}$ asphyxiation and brains were extracted and dissected in cerebellum and prefrontal cortex tissue samples and placed into pre-weighed $2 \mathrm{ml}$ tubes. Upon collection, all tissue samples were weighed, snap frozen in liquid nitrogen and stored at $-80{ }^{\circ} \mathrm{C}$ for analysis.

\section{Compound Synthesis}

\section{Materials and Methods}

All chemicals were purchased from commercial suppliers and used as received.

Liquid Chromatography-Mass Spectrometry

UPLC-MS was performed on a Waters Acquity I-Class with Waters Diode Array Detector coupled to a Waters SQD2 single quadrupole mass spectrometer using an Waters HSS C18 column $(1.8 \mu \mathrm{m}, 100 \times 2.1 \mathrm{~mm})$ or on a Waters DAD + Waters SQD2, single quadrupole UPLC-MS spectrometer using an Acquity UPLC BEH Shield RP18 1.7 um $100 \times 2.1 \mathrm{~mm}$ (plus guard cartridge), maintained at $40{ }^{\circ} \mathrm{C}$. The columns were initially held at $5 \%$ acetonitrile/water (with $0.1 \%$ formic acid or $10 \mathrm{mM}$ ammonium bicarbonate in each mobile phase), followed by a linear gradient of $5-100 \%$ and then held at $100 \%$. 
${ }^{1} \mathrm{H}$ Nuclear magnetic resonance (NMR) spectroscopy was carried out using a Bruker instrument operating at 400 $\mathrm{MHz}$ using the stated solvent at around room temperature unless otherwise stated. In all cases, NMR data were consistent with the proposed structures. Characteristic chemical shifts $(\delta)$ are given in parts-per-million using conventional abbreviations for designation of major peaks: e.g. s, singlet; d, doublet; t, triplet; q, quartet; dd, doublet of doublets; dt, doublet of triplets; m, multiplet; br, broad.

\section{Preparative reverse-phase HPLC conditions}

Preparative HPLC purification was performed by reverse phase HPLC using a Waters Fractionlynx preparative HPLC system (2525 pump, 2996/2998 UV/VIS detector, 2767 liquid handler) or an equivalent HPLC system such as a Gilson Trilution UV directed system. The Waters 2767 liquid handler acted as both auto-sampler and fraction collector. The columns used for the preparative purification of the compounds were a Waters Sunfire OBD Phenomenex Luna Phenyl Hexyl or Waters Xbridge Phenyl at $10 \mu \mathrm{m} 19 \times 150 \mathrm{~mm}$ or Waters CSH Phenyl Hexyl, $19 \times 150,5 \mu \mathrm{m}$ column. Appropriate focused gradients were selected based on acetonitrile and methanol solvent systems under either acidic or basic conditions. The modifiers used under acidic/basic conditions were formic acid or trifluoroacetic acid $(0.1 \% \mathrm{~V} / \mathrm{V})$ and ammonium bicarbonate $(10 \mathrm{mM})$ respectively. The purification was controlled by Waters Fractionlynx software through monitoring at $210-400 \mathrm{~nm}$, and triggered a threshold collection value at $260 \mathrm{~nm}$ and, when using the Fractionlynx, the presence of target molecular ion as observed under API conditions. Collected fractions were analyzed by LCMS (Waters Acquity systems with Waters SQD).

The diastereomeric separation of compounds was achieved by Supercritical Fluid Chromatography (SFC) using a Waters Thar Prep100 preparative SFC system (P200 CO2 pump, 2545 modifier pump, 2998 UV/VIS detector, 2767 liquid handler with Stacked Injection Module). The Waters 2767 liquid handler acted as both auto-sampler and fraction collector. Appropriate isocratic methods were selected based on methanol, ethanol or isopropanol solvent systems under un-modified or basic conditions. The standard SFC method used was modifier, $\mathrm{CO} 2,100 \mathrm{~mL} / \mathrm{min}$, $120 \mathrm{Bar}$ backpressure, $40{ }^{\circ} \mathrm{C}$ column temperature. The modifier used under basic conditions was diethylamine $(0.1 \% \mathrm{~V} / \mathrm{V})$. The modifier used under acidic conditions was either formic acid $(0.1 \% \mathrm{~V} / \mathrm{V})$ or trifluoroacetic acid $(0.1 \% \mathrm{~V} / \mathrm{V})$. The SFC purification was controlled by Waters Fractionlynx software through monitoring at 210-400 $\mathrm{nm}$ and triggered at a threshold collection value, typically $260 \mathrm{~nm}$. Collected fractions were analyzed by SFC (Waters/Thar SFC systems with Waters SQD). The fractions that contained the desired product were concentrated by vacuum centrifugation.

\section{Supercritical Fluid Chromatography - Mass Spectrometry analytical conditions}

\section{Method 1}

SFC-MS was performed on a Waters/Thar SFC systems with Waters SQD using a Lux Cellulose-3 column with a $15 \%$ methyl alcohol $/ \mathrm{CO}_{2}$ (with $0.5 \%$ diethylamine) isocratic run at $5 \mathrm{~mL} / \mathrm{min}, 120$ Bar backpressure, $40{ }^{\circ} \mathrm{C}$ column temperature.

Method 2

SFC-MS was performed on a Waters/Thar SFC systems with Waters SQD using a YMC Amylose-C column with a $30 \%$ (methyl alcohol $/ \mathrm{MeCN}$ ) $/ \mathrm{CO}_{2}$ isocratic run at $5 \mathrm{~mL} / \mathrm{min}, 120$ Bar backpressure, $40{ }^{\circ} \mathrm{C}$ column temperature.

Method 3 
SFC-MS was performed on a Waters/Thar SFC systems with Waters SQD using a YMC Cellulose-C column with a $5-60 \%$ IPA (with $0.1 \%$ diethylamine) $/$ heptane isocratic run at $1 \mathrm{~mL} / \mathrm{min}, 120$ Bar backpressure, $40{ }^{\circ} \mathrm{C}$ column temperature.

All final compounds except $\mathbf{5 4}$ have demonstrated HPLC purity $>95 \%$. Compound $\mathbf{5 4}$ has a purity of $93.1 \%$ by LCMS analysis.

Synthesis of 5-(4-(Trifluoromethyl)phenethyl)-1,4-dihydropyrazine-2,3-dione (12)

Step A: (E)-2,3-Dimethoxy-5-(4-(trifluoromethyl)styryl)pyrazine

To a degassed mixture of 5-bromo-2,3-dimethoxypyrazine (1.10 g, $5.00 \mathrm{mmol}),(E)$-(4-

(trifluoromethyl)styryl)boronic acid $(2.16 \mathrm{~g}, 10.0 \mathrm{mmol})$ and sodium carbonate $(1.59 \mathrm{~g}, 15.0 \mathrm{mmol})$ in 1,4-dioxane $(30 \mathrm{~mL})$ and water $(10 \mathrm{~mL})$ was added tetrakis(triphenylphosphine $) \operatorname{Pd}(0)(0.58 \mathrm{~g}, 0.50 \mathrm{mmol})$ and the reaction was heated to $95{ }^{\circ} \mathrm{C}$ for $4 \mathrm{hrs}$. The reaction was cooled to room temperature and diluted with ethyl acetate $(10 \mathrm{~mL})$. The organics were separated and further extracted with ethyl acetate $(2 \times 10 \mathrm{~mL})$. The combined organics were washed with brine $(10 \mathrm{~mL})$, dried over sodium sulfate, filtered and concentrated under reduced pressure. The crude material was purified by flash column chromatography $(0-100 \%$ dichloromethane in iso-hexane) to yield the title compound as a yellow solid (1.45 g, 94\%). ${ }^{1} \mathrm{H} \mathrm{NMR}\left(\mathrm{CDCl}_{3}, 400 \mathrm{MHz}\right) \delta 7.65-7.60(\mathrm{~m}, 5 \mathrm{H}), 7.52(\mathrm{~d}, J=15.5 \mathrm{~Hz}$, $1 \mathrm{H}), 7.09$ (d, $J=15.5 \mathrm{~Hz}, 1 \mathrm{H}), 4.13(\mathrm{~s}, 3 \mathrm{H}), 4.05(\mathrm{~s}, 3 \mathrm{H})$.

Step B: 2,3-Dimethoxy-5-(4-(trifluoromethyl)phenethyl)pyrazine

To a degassed solution of (E)-2,3-dimethoxy-5-(4-(trifluoromethyl)styryl)pyrazine (1.45 g, $4.67 \mathrm{mmol}$ ) and 1methyl-1,4-cyclohexadiene (10.5 mL, $93.5 \mathrm{mmol})$ in dry ethanol $(80 \mathrm{~mL})$ was added Pdhydroxide (20\% on carbon, $1.47 \mathrm{~g}, 2.09 \mathrm{mmol}$ ) and the reaction was heated to reflux overnight. The reaction was cooled to room temperature and filtered through Celite ${ }^{\mathrm{TM}}$ under a flow of nitrogen. The filtrate was concentrated under reduced pressure and the crude material was purified by flash column chromatography $(0-15 \%$ ethyl acetate in iso-hexane) yielding the title compound as a pale yellow oil $(1.40 \mathrm{~g}, 96 \%) .{ }^{1} \mathrm{H} \mathrm{NMR}\left(\mathrm{CDCl}_{3}, 400 \mathrm{MHz}\right) \delta 7.51(\mathrm{~d}, J=8.0 \mathrm{~Hz}, 2 \mathrm{H}), 7.36,(\mathrm{~s}, 1 \mathrm{H})$, 7.28 (d, $J=8.0$ Hz. 2 H), 4.00 (s, 3 H), 3.99 (s, 3 H), 3.08 (t, $J=7.5$ Hz, 2 H), 2.93 (t, $J=7.5$ Hz, 2 H).

Step C: 5-(4-(Trifluoromethyl)phenethyl)-1,4-dihydropyrazine-2,3-dione

A solution of 2,3-dimethoxy-5-(4-(trifluoromethyl)phenethyl)pyrazine $(1.40 \mathrm{~g}, 4.48 \mathrm{mmol})$ in $2 \mathrm{M}$ aqueous hydrochloric acid $(23 \mathrm{~mL})$ and 1,4-dioxane $(23 \mathrm{~mL})$ was heated to reflux for $16 \mathrm{hrs}$. The reaction was cooled to room temperature and concentrated under reduced pressure. The crude material was purified by flash column chromatography $\left(0-20 \%\right.$ methanol in DCM) to afford the title compound a white solid $(720 \mathrm{mg}, 57 \%) .{ }^{1} \mathrm{H}$ NMR (DMSO- $\left.d_{6}, 400 \mathrm{MHz}\right) \delta 11.40(\mathrm{~s}, 1 \mathrm{H}), 11.01(\mathrm{~s}, 1 \mathrm{H}), 7.67$ (d, J = 8.0 Hz, $\left.2 \mathrm{H}\right), 7.45$ (d, J = 8.0 Hz, $\left.2 \mathrm{H}\right), 6.01$ (s, 1 $\mathrm{H}), 2.90(\mathrm{t}, \mathrm{J}=8.0 \mathrm{~Hz}, 2 \mathrm{H}), 2.51(\mathrm{t}, \mathrm{J}=8.0 \mathrm{~Hz}, 2 \mathrm{H}) . \mathrm{MS}(\mathrm{ESI}+) \mathrm{m} / \mathrm{z} 285.1(\mathrm{M}+\mathrm{H})^{+}$.

The following compounds were prepared following the same procedure as $\mathbf{1 2}$.

5-(4-Chlorophenethyl)-1,4-dihydropyrazine-2,3-dione (15): ' ${ }^{\mathrm{H}} \mathrm{NMR}$ (400 MHz, DMSO) d 11.33 (s, $\left.1 \mathrm{H}\right), 10.98$ (s, $1 \mathrm{H}), 7.35$ (dt, J=9.0, $2.3 \mathrm{~Hz}, 2 \mathrm{H}), 7.24$ (dt, J=9.0, $2.3 \mathrm{~Hz}, 2 \mathrm{H}), 5.98$ (s, 1H), 2.80 (t, J=7.8 Hz, 2H), 2.47 (t, J=7.8 Hz, 2H). MS (ESI+) m/z 251.1, (M+H) ${ }^{+}$. 
5-(4-Methoxyphenethyl)-1,4-dihydropyrazine-2,3-dione (20): ' ${ }^{\mathrm{H}}$ NMR (400 MHz, DMSO): $\delta$ 11.33-11.28 (m, $1 \mathrm{H}$ ), 11.02-10.97 (m, 1 H), 7.13 (d, J = 8.7 Hz, 2 H), 6.85 (d, J = 8.7 Hz, 2 H), 5.97 (s, 1 H), 3.72 (s, 3 H), 2.77-2.71 (m, 2 H), 2.48-2.41 (m, 2 H). MS (ESI+) m/z $247(\mathrm{M}+\mathrm{H})^{+}$.

5-(3-Chlorophenethyl)-1,4-dihydropyrazine-2,3-dione (21): ${ }^{1} \mathrm{H}$ NMR (400 MHz, DMSO): $\delta$ 11.33-11.32 (m, $1 \mathrm{H}$ ), 10.98-10.98 (m, 1 H), 7.36-7.24 (m, 3 H), 7.18 (d, J = 7.6 Hz, 1 H), 6.01 (s, 1 H), 2.85-2.78 (m, 2 H), 2.50-2.47 (m, $2 \mathrm{H})$. MS (ES+) m/z $251(\mathrm{M}+\mathrm{H})^{+}$.

5-(2-Chlorophenethyl)-1,4-dihydropyrazine-2,3-dione (22): ' $\mathrm{H}$ NMR (400 MHz, DMSO): $\delta 11.36$ (s, $1 \mathrm{H}), 10.99$ (s, $1 \mathrm{H}), 7.42$ (dd, J = 1.4, 7.7 Hz, 1 H), 7.36-7.22 (m, 3 H), 5.93 (s, 1 H), 2.98-2.91 (m, 2 H), 2.51-2.48 (m, 2 H). MS $(\mathrm{ES}+) \mathrm{m} / \mathrm{z} 251(\mathrm{M}+\mathrm{H})^{+}$.

5-Phenethyl-1,4-dihydropyrazine-2,3-dione (18): 2,3-Dimethoxy-5-phenethylpyrazine was isolated as a by-product from the reduction of (E)-5-(4-chlorostyryl)-2,3-dimethoxypyrazine and deprotection of 2,3-dimethoxy-5phenethylpyrazine following the general procedure used to prepare 5-(4-(trifluoromethyl)phenethyl)-1,4dihydropyrazine-2,3-dione. ${ }^{1} \mathrm{H}$ NMR (400 MHz, DMSO) $\delta 11.35$ (s, $\left.1 \mathrm{H}\right), 10.98$ (s, $\left.1 \mathrm{H}\right), 7.32$ - 7.27 (m, $\left.2 \mathrm{H}\right), 7.23$ 7.19 (m, 3 H), 5.99 (s, 1 H), 2.81 (t, J=8.0 Hz, 2 H), 2.52 - 2.45 (m, 2 H). MS (ESI-) m/z 215.1 (M-H)-

5-(3,5-Dichlorophenethyl)-1,4-dihydropyrazine-2,3-dione (24)

Step A: 2,3-Dimethoxy-5-((trimethylsilyl)ethynyl)pyrazine

Anhydrous THF (50 mL) was added to 5-bromo-2,3-dimethoxypyrazine (4.6 g, $20 \mathrm{mmol})$, bis(triphenylphosphine)Pd(II) dichloride (0.98 g, $1.4 \mathrm{mmol})$ and copper (I) iodide ( $0.11 \mathrm{~g}, 0.6 \mathrm{mmol})$ and degassed with a stream of nitrogen whilst being stirred at room temperature. Triethylamine $(6.0 \mathrm{~g}, 60 \mathrm{mmol})$ was added followed by ethynyltrimethylsilane $(2.45 \mathrm{~g}, 25 \mathrm{mmol})$ and the mixture was stirred at room temperature for $18 \mathrm{hrs}$. The mixture was partitioned between water $(100 \mathrm{~mL})$ and ethyl acetate $(200 \mathrm{~mL})$ and the aqueous layer was extracted with further portions of ethyl acetate $(3 \times 100 \mathrm{~mL})$. The combined organic extracts were washed with brine $(100 \mathrm{~mL})$, dried over sodium sulfate, filtered and evaporated. The crude material was purified by flash column chromatography (0-10\% ethyl acetate in cyclohexane) to elute the desired product as a yellow oil $(4.7 \mathrm{~g}, 99 \%) .{ }^{1} \mathrm{H}$ NMR (400 MHz, $\left.\mathrm{CDCl}_{3}\right): \delta 7.81$ (s, $\left.1 \mathrm{H}\right), 4.05-4.03(\mathrm{~m}, 6 \mathrm{H}), 0.28-0.27(\mathrm{~m}, 9 \mathrm{H})$.

Step B: 5-Ethynyl-2,3-dimethoxypyrazine 2,3-Dimethoxy-5-((trimethylsilyl)ethynyl)pyrazine (4.7 g, $20 \mathrm{mmol})$, was dissolved in methanol $(60 \mathrm{~mL})$ and stirred at room temperature. Potassium carbonate $(2.8 \mathrm{~g}, 20 \mathrm{mmol})$ was added and the mixture was stirred at room temperature for $5.5 \mathrm{hrs}$. The solution was partitioned between dichloromethane $(200 \mathrm{~mL})$ and water $(100 \mathrm{~mL})$ and the aqueous layer was extracted with further portions of dichloromethane $(3 \times 100 \mathrm{~mL})$. The combined organic extracts were washed with brine $(100 \mathrm{~mL})$, dried over sodium sulfate, filtered and evaporated. The crude material was purified by flash column chromatography (0-10\% ethyl acetate in cyclohexane) to elute the desired product as an off-white solid (2.85 g, 87\%). ${ }^{1} \mathrm{H}$ NMR (400 MHz, $\left.\mathrm{CDCl}_{3}\right)$ : $\delta 7.84(\mathrm{~s}, 1 \mathrm{H}), 4.04(\mathrm{~d}, \mathrm{~J}=3.0 \mathrm{~Hz}, 6 \mathrm{H}), 3.16(\mathrm{~s}, 1$ $\mathrm{H})$.

Step C: 5-((3,5-Dichlorophenyl)ethynyl)-2,3-dimethoxypyrazine 
A solution of 5-ethynyl-2,3-dimethoxypyrazine ( $0.16 \mathrm{~g}, 1 \mathrm{mmol}), 1$-bromo-3,5-dichlorobenzene $(0.24 \mathrm{~g}, 1.1 \mathrm{mmol})$ and triethylamine $(0.3 \mathrm{~g}, 0.42 \mathrm{~mL}, 3 \mathrm{mmol})$ in DMF $(12 \mathrm{~mL})$ was degassed with a stream of nitrogen for 1 minute. Copper iodide (0.019 g, $0.1 \mathrm{mmol})$ and bis(triphenylphosphine)Pd(II) dichloride $(0.1 \mathrm{~g}, 0.15 \mathrm{mmol})$ were added and the mixture was stirred at room temperature for $18 \mathrm{hrs}$. The mixture was diluted with ethyl acetate $(30 \mathrm{~mL})$ and filtered through a plug of Celite ${ }^{\mathrm{TM}}$. Water $(50 \mathrm{~mL})$ was added to the filtrate and the organic layer extracted. The aqueous layer was extracted with further portions of ethyl acetate $(2 \times 30 \mathrm{~mL})$. The organic layers were combined, dried over magnesium sulfate, filtered and concentrated. The crude material was purified by flash column chromatography (5\% ethyl acetate in cyclohexane isocratic) to afford the title compound as a yellow solid $(0.29 \mathrm{~g}$, 94\%). ${ }^{1} \mathrm{H}$ NMR (400 MHz, DMSO): $\delta 7.79$ (s, $\left.1 \mathrm{H}\right), 7.65$ (m, $\left.1 \mathrm{H}\right)$, 7.48-7.42 (m, $\left.1 \mathrm{H}\right)$, 7.33-7.20 (m, $\left.1 \mathrm{H}\right), 4.02$ (m, $3 \mathrm{H}), 3.94$ (s, $3 \mathrm{H})$.

Step D: 5-(3,5-Dichlorophenethyl)-2,3-dimethoxypyrazine $10 \%$ Palladium hydroxide on carbon ( $0.1 \mathrm{~g})$ was added to a solution of 5-((3,5-dichlorophenyl)ethynyl)-2,3dimethoxypyrazine $(0.28 \mathrm{~g}, 0.9 \mathrm{mmol})$ and 1-methyl-1,4-cyclohexadiene $(1.7 \mathrm{~g}, 18 \mathrm{mmol})$ and the mixture stirred at $65{ }^{\circ} \mathrm{C}$ for $3 \mathrm{~h}$. A further portion of 1-methyl-1,4-cyclohexadiene $(1.7 \mathrm{~g}, 18 \mathrm{mmol})$ was added and the mixture was stirred at $65{ }^{\circ} \mathrm{C}$ for a further $3 \mathrm{hrs}$. The solution was then cooled and filtered through a plug of Celite ${ }^{\mathrm{TM}}$. The Celite $^{\mathrm{TM}}$ was washed with a portion of ethyl acetate $(10 \mathrm{~mL})$, dichoromethane $(10 \mathrm{~mL})$ and methanol $(10 \mathrm{~mL})$. The filtrate was concentrated in vacuo and the crude residue partitioned between water $(10 \mathrm{~mL})$ and ethyl acetate $(10$ $\mathrm{mL})$. The organic layer was washed with brine $(10 \mathrm{~mL})$ and the combined aqueous layers washed with ethyl acetate $(2 \times 10 \mathrm{~mL})$. The organic layers were combined, dried over magnesium sulfate, filtered and concentrated. The crude material was purified by flash column chromatography (0-10\% ethyl acetate in cyclohexane) to afford the title compound as a pale yellow solid (0.08 g, 28\%). ${ }^{1} \mathrm{H}$ NMR (400 MHz, DMSO): $\delta$ 7.45-7.32 (m, $\left.2 \mathrm{H}\right), 7.23$ (d, J = 1.9 $\mathrm{Hz}, 2 \mathrm{H}), 3.82-3.79$ (m, $6 \mathrm{H}), 2.94-2.81$ (m, 4 H).

Step E: 5-(3,5-Dichlorophenethyl)-1,4-dihydropyrazine-2,3-dione

A solution of 5-(3,5-dichlorophenethyl)-2,3-dimethoxypyrazine $(0.08 \mathrm{~g}, 0.25 \mathrm{mmol})$ in $2 \mathrm{M}$ aqueous hydrochloric acid $(2.6 \mathrm{~mL})$ and 1,4-dioxane $(3 \mathrm{~mL})$ was heated to reflux for $16 \mathrm{hrs}$. The reaction was cooled to room temperature and concentrated under reduced pressure. The crude material was purified by reverse phase preparative HPLC to afford the title compound as a white solid (23 mg, 32\%). ${ }^{1} \mathrm{H}$ NMR (400 MHz, DMSO): $\delta 11.03$ (s, $\left.2 \mathrm{H}\right), 7.45$ (t, J = $1.9 \mathrm{~Hz}, 1 \mathrm{H}), 7.32$ (d, J = $1.9 \mathrm{~Hz}, 2 \mathrm{H}), 6.02$ (s, $1 \mathrm{H}), 2.82$ (t, J = 8.0 Hz, 2 H), 2.49-2.47 (m, 2 H). MS (ES+) m/z 285 $(\mathrm{M}+\mathrm{H})^{+}$.

The following compounds were prepared following the same procedures as compound $\mathbf{2 4}$.

5-(2-(Quinolin-6-yl)ethyl)-1,4-dihydropyrazine-2,3-dione (26): ${ }^{1} \mathrm{H}$ NMR (400 MHz, DMSO): $\delta 11.40$ (s, $1 \mathrm{H}$ ), 10.97-10.92 (m, $1 \mathrm{H}), 8.84(\mathrm{dd}, \mathrm{J}=1.8,4.3 \mathrm{~Hz}, 1 \mathrm{H}), 8.30-8.27$ (m, $1 \mathrm{H}), 7.95(\mathrm{~d}, \mathrm{~J}=8.7 \mathrm{~Hz}, 1 \mathrm{H}), 7.75-7.74(\mathrm{~m}, 1$ H), $7.65(\mathrm{dd}, \mathrm{J}=1.9,8.7 \mathrm{~Hz}, 1 \mathrm{H}), 7.50(\mathrm{dd}, \mathrm{J}=4.1,8.3 \mathrm{~Hz}, 1 \mathrm{H}), 6.00-5.97(\mathrm{~m}, 1 \mathrm{H}), 3.01(\mathrm{t}, \mathrm{J}=7.8 \mathrm{~Hz}, 2 \mathrm{H}), 2.59$ (t, J $=7.8 \mathrm{~Hz}, 2 \mathrm{H})$. MS (ES+) m/z $268(\mathrm{M}+\mathrm{H})^{+}$.

5-(2-(3-(Trifluoromethyl)-1H-indazol-6-yl)ethyl)-1,4-dihydropyrazine-2,3-dione (28): ${ }^{1} \mathrm{H}$ NMR (400 MHz, DMSO): $\delta$ 14.08-13.65 (m, 1 H), 11.51-11.22 (m, 1 H), 11.09-10.83 (m, 1 H), 7.73 (d, J = 8.4 Hz, 1 H), 7.49 (s, 1 H), 7.23 (d, $\mathrm{J}=9.2 \mathrm{~Hz}, 1 \mathrm{H}), 6.00(\mathrm{~s}, 1 \mathrm{H}), 2.98(\mathrm{dd}, \mathrm{J}=7.8,7.8 \mathrm{~Hz}, 2 \mathrm{H}), 2.58-2.53(\mathrm{~m}, 2 \mathrm{H})$. MS (ESI+) m/z $325(\mathrm{M}+\mathrm{H})^{+}$. 
4-(2-(5,6-Dioxo-1,4,5,6-tetrahydropyrazin-2-yl)ethyl)benzonitrile (19)

Sodium iodide $(0.14 \mathrm{~g}, 0.91 \mathrm{mmol})$ and TMSCl $(0.099,0.12 \mathrm{~mL}, 0.91 \mathrm{mmol})$ were added to a solution of 4-(2-(5,6dimethoxypyrazin-2-yl)ethyl)benzonitrile (synthesised following step A-D of $\mathbf{2 4}$, used to prepare 5-(3,5dichlorophenethyl)-1,4-dihydropyrazine-2,3-dione) (0.049 g, $0.18 \mathrm{mmol})$, in acetonitrile $(1 \mathrm{~mL})$ and the solution stirred at room temperature for $2 \mathrm{hrs}$. The mixture was evaporated to dryness and then dissolved in a 1:1:1 mixture of DMSO/ MeCN and water. The crude compound was purified by reverse phase preparative HPLC to afford the title compound as an off-white solid (6 mg, 14\%). ${ }^{1} \mathrm{H}$ NMR (400 MHz, DMSO): $\delta$ 11.38-11.37 (m, $\left.1 \mathrm{H}\right), 11.01$ (s, 1 H), 7.84-7.79 (m, 2 H), 7.49-7.45 (m, 2 H), 6.05-6.01 (m, 1 H), 3.34 (m, 2 H), 2.98-2.91 (m, 2 H). MS (ES+) m/z $242(\mathrm{M}+\mathrm{H})^{+}$.

4-(2-(5,6-dioxo-1,4,5,6-tetrahydropyrazin-2-yl)ethyl)-2-fluorobenzonitrile (23): prepared using an analogous method to that used to prepare compound 19.

${ }^{1} \mathrm{H}$ NMR (400 MHz, DMSO) d 11.32 (s, $\left.1 \mathrm{H}\right), 10.98$ (s, 1 H), 7.86 (dd, J=7.2, 7.9 Hz, 1 H), 7.43 (dd, J=1.4, 10.8

Hz, 1 H), 7.27 (dd, J=1.4, 7.9 Hz, 1 H), 6.01 (s, 1 H), 2.95 - 2.90 (m, 2 H), 2 H obscured by DMSO peak. MS (ESI+) $\mathrm{m} / \mathrm{z} 260(\mathrm{M}+\mathrm{H})^{+}$.

5-(2-(6-(Difluoromethoxy)pyridin-3-yl)ethyl)-1,4-dihydropyrazine-2,3-dione (25)

Step A: 2,3-Bis(benzyloxy)-5-bromopyrazine

To a solution of 2,3-bis(benzyloxy)pyrazine $(2.5 \mathrm{~g}, 8.6 \mathrm{mmol})$ in DMF $(15 \mathrm{~mL})$ was added $N$-bromosuccinimide $(1.6 \mathrm{~g}, 9 \mathrm{mmol})$ in one portion and the reaction mixture was stirred at room temperature for $48 \mathrm{hrs}$. A further portion of $\mathrm{N}$-bromosuccinimide $(1.6 \mathrm{~g}, 9 \mathrm{mmol})$ was added and the solution was stirred at room temperature for a further 48 hrs. The reaction mixture was concentrated under reduced pressure and the resulting crude material purified by flash column chromatography ( $0-30 \%$ diethyl ether in cyclohexane) to elute the desired product as a white solid ( $0.65 \mathrm{~g}$, 21\%). ${ }^{1} \mathrm{H}$ NMR (400 MHz, $\mathrm{CDCl}_{3}$ ): $\delta 7.70$ (s, $\left.1 \mathrm{H}\right), 7.50-7.29$ (m, $\left.10 \mathrm{H}\right), 5.45-5.40$ (m, $4 \mathrm{H}$ ).

Step B: 2,3-Bis(benzyloxy)-5-((trimethylsilyl)ethynyl)pyrazine

Anhydrous THF ( $6 \mathrm{~mL}$ ) was added to 2,3-bis(benzyloxy)-5-bromopyrazine ( $0.65 \mathrm{~g}, 1.75 \mathrm{mmol})$, bis(triphenylphosphine)Pd(II) dichloride (0.086 g, $0.123 \mathrm{mmol}$ ) and copper (I) iodide ( $0.01 \mathrm{~g}, 0.0525 \mathrm{mmol})$ and degassed with a stream of nitrogen whilst being stirred room temperature. Triethylamine $(0.53 \mathrm{~g}, 0.73 \mathrm{~mL}, 5.25$ mmol) was added followed by ethynyltrimethylsilane $(0.21 \mathrm{~g}, 2.2 \mathrm{mmol})$ and the mixture was stirred at $55^{\circ} \mathrm{C}$ for 18 hrs. The mixture was filtered through a plug of silica and washed with ethyl acetate $(2 \times 10 \mathrm{~mL})$. The filtrate was concentrated under reduced pressure and the resulting crude material purified by flash column chromatography ( 0 $10 \%$ ethyl acetate in cyclohexane) to elute the desired product as a pale brown solid ( $0.68 \mathrm{~g}$, quant.). ${ }^{1} \mathrm{H}$ NMR (400 $\left.\mathrm{MHz}, \mathrm{CDCl}_{3}\right): \delta 7.81(\mathrm{~s}, 1 \mathrm{H}), 7.49-7.28(\mathrm{~m}, 10 \mathrm{H}), 5.47-5.45(\mathrm{~m}, 4 \mathrm{H}), 0.28-0.28(\mathrm{~m}, 9 \mathrm{H})$.

Step C: 2,3-Bis(benzyloxy)-5-ethynylpyrazine

2,3-bis(benzyloxy)-5-((trimethylsilyl)ethynyl)pyrazine (0.68 g, $1.75 \mathrm{mmol})$, was dissolved in methanol (18 $\mathrm{mL})$ and stirred at room temperature. Potassium carbonate $(0.24 \mathrm{~g}, 1.75 \mathrm{mmol})$ was added and the mixture was stirred at room temperature for $2.5 \mathrm{hrs}$. The solution was partitioned between dichloromethane $(40 \mathrm{~mL})$ and water $(4 \mathrm{~mL})$ and the aqueous layer was extracted with further portions of dichloromethane $(2 \times 10 \mathrm{~mL})$. The combined organic extracts were washed with brine $(100 \mathrm{~mL})$, passed through a phase separator and evaporated. The crude material was 
purified by flash column chromatography ( $0-25 \%$ diethyl ether in cyclohexane) to elute the desired product as an light brown solid (0.49 g, 88\%). ${ }^{1} \mathrm{H}$ NMR (400 MHz, $\left.\mathrm{CDCl}_{3}\right)$ : $\delta$ 7.84-7.83 (m, $\left.1 \mathrm{H}\right), 7.50-7.42(\mathrm{~m}, 4 \mathrm{H}), 7.40-7.30$ (m, $6 \mathrm{H})$, 5.47-5.45 (m, $4 \mathrm{H}), 3.16-3.14(\mathrm{~m}, 1 \mathrm{H})$.

Step D: 2,3-Bis(benzyloxy)-5-((6-(difluoromethoxy)pyridin-3-yl)ethynyl)pyrazine

A solution of 2,3-bis(benzyloxy)-5-ethynylpyrazine ( $0.26 \mathrm{~g}, 0.82 \mathrm{mmol}$ ), 5-bromo-2-(difluoromethoxy)pyridine $(0.23 \mathrm{~g}, 1.0 \mathrm{mmol})$ and triethylamine $(0.25 \mathrm{~g}, 0.34 \mathrm{~mL}, 2.5 \mathrm{mmol})$ were dissolved in acetonitrile $(10 \mathrm{~mL})$ and degassed with a stream of nitrogen for 1 minute. Copper iodide $(0.005 \mathrm{~g}, 0.024 \mathrm{mmol})$ and bis(triphenylphosphine)Pd(II) dichloride $(0.04 \mathrm{~g}, 0.06 \mathrm{mmol})$ were added and the mixture was stirred at $70{ }^{\circ} \mathrm{C}$ for 18 hrs. The mixture was diluted with ethyl acetate $(10 \mathrm{~mL})$ and filtered through a plug of Celite ${ }^{\mathrm{TM}}$. Water $(10 \mathrm{~mL})$ was added to the filtrate and the organic layer extracted. The aqueous layer was washed with further portions of ethyl acetate $(2 \times 10 \mathrm{~mL})$. The organic layers were combined, dried over magnesium sulfate, filtered and concentrated. The crude material was purified by flash column chromatography (0-50\% dichloromethane in cyclohexane) to afford the title compound as a yellow oil $(0.08 \mathrm{~g}, 21 \%)$. ${ }^{1} \mathrm{H}$ NMR $\left(400 \mathrm{MHz}, \mathrm{CDCl}_{3}\right): \delta 7.72(\mathrm{dd}, \mathrm{J}=7.1,13.4 \mathrm{~Hz}, 5$ H), 7.53-7.30 (m, $10 \mathrm{H}), 5.48(\mathrm{~d}, \mathrm{~J}=10.6 \mathrm{~Hz}, 4 \mathrm{H})$.

Step E: 5-(2-(6-(Difluoromethoxy)pyridin-3-yl)ethyl)-1,4-dihydropyrazine-2,3-dione Pd hydroxide on carbon (0.02 g) was added to a solution of 2,3-bis(benzyloxy)-5-((6-(difluoromethoxy)pyridin-3yl)ethynyl)pyrazine $(0.015 \mathrm{~g}, 0.033 \mathrm{mmol})$ and 1-methyl-1,4-cyclohexadiene $(0.061 \mathrm{~g}, 0.653 \mathrm{mmol})$ and the mixture stirred at $85{ }^{\circ} \mathrm{C}$ for $18 \mathrm{hrs}$. The solution was cooled and filtered through a plug of Celite ${ }^{\mathrm{TM}}$. The Celite ${ }^{\mathrm{TM}}$ was washed with ethyl acetate $(5 \mathrm{~mL})$, dichoromethane $(5 \mathrm{~mL})$ and methanol $(5 \mathrm{~mL})$. The filtrate was concentrated in vacuo and the crude residue purified by reverse preparative HPLC to afford the title compound as a white solid (1 mg, 7\%). ${ }^{1} \mathrm{H}$ NMR (400 MHz, DMSO): $\delta$ 11.34-11.33 (m, 1 H), 11.00-10.99 (m, 1 H), 8.08-8.07 (m, 1 H), 7.78-7.74 (m, 1 H), 7.67 (t, J =73.1 Hz, 1 H), 7.04-7.01 (m, 1 H), 5.98 (s, 1 H), 2.84-2.78 (m, 2 H), 2.48-2.44 (m, 2 H). MS (ES+) m/z 284 $(\mathrm{M}+\mathrm{H})^{+}$.

5-(3-Fluoro-4-(3-hydroxy-1H-pyrazol-5-yl)phenethyl)-1,4-dihydropyrazine-2,3-dione (27)

Step A: 4-(2-(5,6-Dimethoxypyrazin-2-yl)ethyl)-2-fluorobenzoic acid

Tert-butyl 4-(2-(5,6-dimethoxypyrazin-2-yl)ethyl)-2-fluorobenzoate (synthesized following general procedures A-D of compound 24) (0.42 g, $1.17 \mathrm{mmol})$ was stirred at room temperature in dichloromethane (15 mL) with trifluoroacetic acid $(4.0 \mathrm{~g}, 2.7 \mathrm{~mL}, 35 \mathrm{mmol})$ for $3 \mathrm{hrs}$. The mixture was concentrated under reduced pressure to afford the title compound as a white solid (0.35 g, 98\%). ${ }^{1} \mathrm{H}$ NMR (400 MHz, $\left.\mathrm{CDCl}_{3}\right): \delta 7.92(\mathrm{dd}, \mathrm{J}=7.8,7.8 \mathrm{~Hz}, 1$ H), 7.38 (s, 1 H), 7.06-6.98 (m, 2 H), 4.01 (s, 3 H), 3.99 (s, 3 H), 3.11-3.06 (m, 2 H), 2.97-2.91 (m, 2 H). Acidic OH not observed.

Step B: Ethyl 3-(4-(2-(5,6-dimethoxypyrazin-2-yl)ethyl)-2-fluorophenyl)-3-oxopropanoate Magnesium chloride $(0.1 \mathrm{~g}, 1.1 \mathrm{mmol})$ and ethyl potassium malonate $(0.26 \mathrm{~g}, 1.5 \mathrm{mmol})$ were combined in dry THF ( $3 \mathrm{~mL})$ and heated to reflux for $4 \mathrm{hrs.} \mathrm{4-(2-(5,6-Dimethoxypyrazin-2-yl)ethyl)-2-fluorobenzoic} \mathrm{acid} \mathrm{(0.35} \mathrm{g,} 1.14$ $\mathrm{mmol})$ and CDI $(0.22 \mathrm{~g}, 1.4 \mathrm{mmol})$ were combined in dry THF $(3 \mathrm{~mL})$ and heated to reflux for $30 \mathrm{~min}$. Both solutions were cooled down to room temperature and then the mixture of 4-(2-(5,6-dimethoxypyrazin-2-yl)ethyl)-2fluorobenzoic acid and CDI was added portion-wise to the mixture of magnesium chloride and ethyl potassium 
malonate. The resulting suspension was stirred at room temperature for $18 \mathrm{hrs}$. The mixture was cooled to $0{ }^{\circ} \mathrm{C}$, quenched with $1 \mathrm{M}$ hydrochloric acid solution (aq) $(10 \mathrm{~mL})$, diluted with ethyl acetate $(10 \mathrm{~mL})$ and then stirred for 1 hour. The mixture was further diluted with water $(10 \mathrm{~mL})$ and ethyl acetate $(10 \mathrm{~mL})$ and the aqueous layer extracted with ethyl acetate $(3 \times 40 \mathrm{~mL})$. The combined organic layers were then washed with brine, dried over magnesium sulfate, filtered and concentrated. The crude material was purified by flash column chromatography (10-30\% ethyl acetate in cyclohexane) to afford the title compound as a pale-yellow oil $(0.35 \mathrm{~g}, 83 \%) .{ }^{1} \mathrm{H}$ NMR $(400 \mathrm{MHz}$, $\mathrm{CDCl}_{3}$ ): $\delta$ 7.88-7.76 (m, $\left.1 \mathrm{H}\right)$, 7.38-7.37 (m, $\left.1 \mathrm{H}\right)$, 7.08-6.92 (m, $\left.2 \mathrm{H}\right), 4.24$ (ddd, J = 6.5, 13.7, 20.7 Hz, 2 H), 4.01 3.98 (m, 6 H), 3.10-3.02 (m, 2 H), 2.96-2.91 (m, 2 H), 1.44-1.42 (m, 1 H), 1.34-1.24 (m, 4 H).

Step C: 5-(3-Fluoro-4-(3-hydroxy-1H-pyrazol-5-yl)phenethyl)-1,4-dihydropyrazine-2,3-dione

Ethyl 3-(4-(2-(5,6-dimethoxypyrazin-2-yl)ethyl)-2-fluorophenyl)-3-oxopropanoate $\left(\begin{array}{lllll}0.35 & \mathrm{~g}, & 0.84 \mathrm{mmol}) & \text { was }\end{array}\right.$ dissolved in dry methanol $(3 \mathrm{~mL})$ under a nitrogen atmosphere. Glacial acetic acid $(5.7 \mathrm{mg}, 0.0054 \mathrm{~mL}, 0.094 \mathrm{mmol})$ was added followed by hydrazine hydrate $(0.23 \mathrm{~g}, 0.23 \mathrm{~mL}, 4.7 \mathrm{mmol})$ and the reaction mixture was heated to reflux for $3 \mathrm{hrs}$. The mixture was cooled to room temperature and then evaporated to dryness. The crude material was purified by flash column chromatography (10-30\% ethyl acetate in cyclohexane) to afford 5-(4-(2-(5,6-Dimethoxypyrazin-2yl)ethyl)-2-fluorophenyl)-1H-pyrazol-3-ol as a white solid (0.23 g, 78\%). 5-(4-(2-(5,6-Dimethoxypyrazin-2yl)ethyl)-2-fluorophenyl)-1H-pyrazol-3-ol $(0.23 \mathrm{~g}, 0.66 \mathrm{mmol})$ was treated with $2 \mathrm{~N} \mathrm{HCl}$ to afford the title compound (0.014 g, 18\%). ${ }^{1} \mathrm{H}$ NMR (400 MHz, DMSO) $\delta 12.04$ (s, $\left.1 \mathrm{H}\right), 11.35$ (s, $\left.1 \mathrm{H}\right), 11.00$ (s, $\left.1 \mathrm{H}\right), 9.72$ (s, $\left.1 \mathrm{H}\right), 7.74-7.65$ $(\mathrm{m}, 1 \mathrm{H}), 7.15(\mathrm{~d}, \mathrm{~J}=12.4 \mathrm{~Hz}, 1 \mathrm{H}), 7.09$ (d, J=8.0 Hz, $1 \mathrm{H}), 6.01(\mathrm{~s}, 1 \mathrm{H}), 5.82(\mathrm{~s}, 1 \mathrm{H}), 2.87$ - 2.81 (m, $2 \mathrm{H}),(2 \mathrm{H}$ obscured by DMSO peak). MS (ESI+) m/z $317(\mathrm{M}+\mathrm{H})^{+}$.

5-Chloro-6-(4-(trifluoromethyl)phenethyl)-1,4-dihydropyrazine-2,3-dione (29)

Stap A: 2-Chloro-5,6-dimethoxy-3-(4-(trifluoromethyl)phenethyl)pyrazine

2,3-Dimethoxy-5-(4-(trifluoromethyl)phenethyl)pyrazine $(0.1 \mathrm{~g}, 0.32 \mathrm{mmol}$ ) was dissolved in DMF (3.2 $\mathrm{mL})$ and $N$ chlorosuccinimide $(0.051 \mathrm{~g}, 0.384 \mathrm{mmol})$ was added. The reaction mixture was stirred at $50{ }^{\circ} \mathrm{C}$ for $2 \mathrm{hrs}$ and then for $18 \mathrm{hrs}$ at room temperature. The mixture was concentrated in vacuo and dissolved in ethyl acetate $(5 \mathrm{~mL})$ and washed with water $(2 \times 5 \mathrm{~mL})$ and brine $(5 \mathrm{~mL})$. The organic phase was dried over sodium sulfate, filtered and concentrated. The crude material was purified by flash column chromatography ( $0-10 \%$ ethyl acetate in cyclohexane) to elute the title product as a white solid $(0.084 \mathrm{~g}, 76 \%)$. ${ }^{1} \mathrm{H}$ NMR $\left(400 \mathrm{MHz}, \mathrm{CDCl}_{3}\right): \delta$ 7.55-7.51 (m, 2 H), 7.35-7.30 (m, 2 H), 4.01 (s, 3 H), 3.96 (s, 3 H), 3.09 (s, 4 H).

Step B: 5-Chloro-6-(4-(trifluoromethyl)phenethyl)-1,4-dihydropyrazine-2,3-dione

5-Chloro-6-(4-(trifluoromethyl)phenethyl)-1,4-dihydropyrazine-2,3-dione was prepared following step E of compound 24 (0.055 g, 41\%). ' $\mathrm{H}$ NMR (400 MHz, DMSO): $\delta 12.01$ (s, $1 \mathrm{H}), 11.64$ (s, $1 \mathrm{H}), 7.67$ (d, J=8.0 Hz, 2 H), 7.45 (d, J=8.0 Hz, 2 H), 2.90 (dd, J=7.7, 7.7 Hz, 2 H), 2.62 (dd, J=7.5, 7.5 Hz, 2 H). MS (ESI+) m/z $319.2(\mathrm{M}+\mathrm{H})^{+}$.

5-Methyl-6-(4-(trifluoromethyl)phenethyl)-1,4-dihydropyrazine-2,3-dione (31)

Step A: 2,3-Dimethoxy-5-methyl-6-(4-(trifluoromethyl)phenethyl)pyrazine

To a stirred solution of 2-chloro-5,6-dimethoxy-3-(4-(trifluoromethyl)phenethyl)pyrazine (0.042 g, $0.121 \mathrm{mmol})$ and $\operatorname{Pd}(\mathrm{dppf})_{2} \mathrm{Cl}_{2}(0.0089 \mathrm{~g}, 0.012 \mathrm{mmol})$ in toluene $(1 \mathrm{~mL})$ was added dimethyl zinc $(0.24 \mathrm{~mL}, 2 \mathrm{M}$ solution in toluene, 
$0.48 \mathrm{mmol})$ and the reaction mixture was heated at $80{ }^{\circ} \mathrm{C}$ for $27 \mathrm{hrs}$ before a further portion of $\mathrm{Pd}(\mathrm{dppf}){ }_{2} \mathrm{Cl}_{2}(0.0089$ $\mathrm{g}, 0.0121 \mathrm{mmol}$ ) was added and the reaction was stirred at $80^{\circ} \mathrm{C}$ a further $24 \mathrm{hrs}$. The mixture was cooled and water $(2 \mathrm{~mL})$ added. Ethyl acetate $(5 \mathrm{~mL})$ was added and the organic layer extracted. The aqueous layer was washed with further ethyl acetate $(2 \times 5 \mathrm{~mL})$. The organic layers were combined, dried over magnesium sulfate, filtered and concentrated. The crude material was purified by flash column chromatography ( $0-5 \%$ ethyl acetate in cyclohexane) to afford the title compound as a pale-yellow solid $(0.019 \mathrm{~g}, 48 \%)$. ${ }^{1} \mathrm{H}$ NMR (400 MHz, $\left.\mathrm{CDCl}_{3}\right)$ : $\delta$ 7.53-7.50 (m, 2 H), 7.26 (s, 2 H), 3.98-3.95 (m, 6 H), 3.09-3.04 (m, 2 H), 2.96-2.92 (m, 2 H), 2.24 (s, 3 H).

Step B: 5-Methyl-6-(4-(trifluoromethyl)phenethyl)-1,4-dihydropyrazine-2,3-dione A solution of 2,3-dimethoxy-5-methyl-6-(4-(trifluoromethyl)phenethyl)pyrazine (0.019 g, $0.0582 \mathrm{mmol}$ ) in $2 \mathrm{M}$ aqueous hydrochloric acid $(2 \mathrm{~mL})$ and 1,4-dioxane $(0.6 \mathrm{~mL})$ was heated to reflux for 2 hrs. The reaction was cooled to room temperature and concentrated under reduced pressure. The crude material was purified by flash column chromatography ( $0-20 \%$ methanol in DCM; dry load on Celite ${ }^{\mathrm{TM}} ; 80 \mathrm{~g}$ column) to afford the title compound a white solid (9 mg, 53\%). ${ }^{1} \mathrm{H}$ NMR (400 MHz, DMSO): $\delta 11.20$ (s, $\left.1 \mathrm{H}\right), 11.01$ (s, $\left.1 \mathrm{H}\right), 7.68$ - 7.64 (m, $\left.2 \mathrm{H}\right), 7.47$ 7.43 (m, 2 H), 2.87 - 2.81 (m, 2 H), 1.68 (s, 3 H) 2 H obscured by DMSO peak. MS (ESI+) m/z 299 (M+H) ${ }^{+}$.

5,6-Dioxo-3-(4-(trifluoromethyl)phenethyl)-1,4,5,6-tetrahydropyrazine-2-carbonitrile (32)

Step A: 5,6-Dimethoxy-3-(4-(trifluoromethyl)phenethyl)pyrazine-2-carbonitrile

A solution of 2-chloro-5,6-dimethoxy-3-(4-(trifluoromethyl)phenethyl)pyrazine (0.05 g, 0.144 mmol), Pd(picinnamyl) chloride dimer (0.0075 g, $0.0144 \mathrm{mmol})$, Xphos (0.021 g, $0.0433 \mathrm{mmol})$ and N,N-diisopropylethylamine $(0.037 \mathrm{~g}, 0.288 \mathrm{mmol})$ in previously degassed 1-butanol $(0.7 \mathrm{~mL})$ was heated at $80{ }^{\circ} \mathrm{C}$ under a nitrogen atmosphere. Acetone cyanohydrin $(0.015 \mathrm{~g}, 0.173 \mathrm{mmol})$ solubilized in $0.3 \mathrm{~mL}$ of 1-butanol was then added drop-wise over 4 hrs. After the addition was completed the reaction was stirred at room temperature for $18 \mathrm{hrs}$. Saturated $\mathrm{NaHCO}_{3}(2$ $\mathrm{mL}$ ) was then added and the reaction mixture was stirred for $10 \mathrm{~min}$. The aqueous solution was extracted with ethyl acetate $(2 \times 5 \mathrm{~mL})$. The organic layers were combined, dried over magnesium sulfate, filtered and concentrated. The crude material was purified by flash column chromatography (0-20\% ethyl acetate in cyclohexane) to afford the title compound as a white solid (0.039 g, 80\%). ${ }^{1} \mathrm{H}$ NMR (400 MHz, $\left.\mathrm{CDCl}_{3}\right): \delta$ 7.56-7.52 (m, $\left.2 \mathrm{H}\right), 7.34-7.31$ (m, $\left.2 \mathrm{H}\right)$, 4.04-4.01 (m, $6 \mathrm{H}), 3.22-3.09$ (m, $4 \mathrm{H})$.

Step B: 5,6-Dioxo-3-(4-(trifluoromethyl)phenethyl)-1,4,5,6-tetrahydropyrazine-2-carbonitrile Sodium iodide $(0.033 \mathrm{~g}, 0.22 \mathrm{mmol})$ and $\mathrm{TMSCl}(0.024,0.028 \mathrm{~mL}, 0.22 \mathrm{mmol})$ were added to a solution of 5,6dimethoxy-3-(4-(trifluoromethyl)phenethyl)pyrazine-2-carbonitrile $(0.025 \mathrm{~g}, 0.074 \mathrm{mmol})$, in acetonitrile $(0.4 \mathrm{~mL})$ and the solution stirred at $60{ }^{\circ} \mathrm{C}$ for $2 \mathrm{hrs}$. The reaction was diluted with ethyl acetate $(2 \mathrm{~mL})$ and washed with water $(2 \mathrm{~mL})$ and brine $(2 \mathrm{~mL})$. The organic layer was dried over magnesium sulfate, filtered and concentrated. Crude compound was purified by reverse phase preparative HPLC to afford the title compound as an off-white solid (6 mg, 26\%). ${ }^{1} \mathrm{H}$ NMR (400 MHz, DMSO): $\delta 11.97$ (s, 2 H), 7.71 - 7.67 (m, 2 H), 7.47 - 7.44 (m, 2 H), 2.98 (t, J=7.6 Hz, 2 H), 2.71 (t, J=7.6 Hz, 2 H). MS (ESI-) m/z 308 (M-H)-

5-(4-Chlorobenzyl)-1,4-dihydropyrazine-2,3-dione (34)

Step A: 5-(4-Chlorobenzyl)-2,3-dimethoxypyrazine 
To a solution of 4-chlorobenzyl magnesium chloride (2.4 mL, 0.5 M soln. in THF, $1.2 \mathrm{mmol}$ ) in THF (1 mL) was added a zinc chloride $(0.7 \mathrm{~mL}, 2 \mathrm{M}$ solution in THF, $1.3 \mathrm{mmol})$ and the mixture was stirred at room temperature for $45 \mathrm{~min}$. A suspension of 5-bromo-2,3-dimethoxypyrazine ( $0.13 \mathrm{~g}, 0.6 \mathrm{mmol})$ and bis(triphenylphosphine) $\mathrm{Pd}(\mathrm{II})$ dichloride in THF $(1 \mathrm{~mL})$ was added and the mixture was stirred at room temperature for $64 \mathrm{hrs}$. The mixture was filtered through Celite ${ }^{\mathrm{TM}}$ and washed with ethyl acetate $(2 \times 5 \mathrm{~mL})$. The filtrate was concentrated under reduced pressure and the resulting yellow residue purified by flash column chromatography (0-20\% ethyl acetate in cyclohexane) to afford the title compound as a colorless solid $(0.09 \mathrm{~g}, 57 \%)$. ${ }^{1} \mathrm{H}$ NMR $\left(400 \mathrm{MHz}, \mathrm{CDCl}_{3}\right): \delta 7.45-$ 7.43 (m, 1 H), 7.25-7.19 (m, 3 H), 7.12-7.06 (m, 1 H), 3.99-3.97 (m, 6 H), 3.91-3.90 (m, 2 H).

Step B: 5-(4-Chlorobenzyl)-1,4-dihydropyrazine-2,3-dione

A solution of 5-(4-chlorobenzyl)-2,3-dimethoxypyrazine( $0.09 \mathrm{~g}, 0.34 \mathrm{mmol})$ in $2 \mathrm{M}$ aqueous hydrochloric acid (3.4 $\mathrm{mL}$ ) and 1,4-dioxane $(3.4 \mathrm{~mL})$ was heated to reflux for 2 hrs. The reaction was cooled to room temperature and concentrated under reduced pressure. The crude material was purified by preparative HPLC to afford the title compound a white solid (17 mg, 22\%). ${ }^{1} \mathrm{H}$ NMR (400 MHz, DMSO): $\delta 11.16$ (s, $\left.2 \mathrm{H}\right), 7.37$ (d, J = 8.4 Hz, $2 \mathrm{H}$ ), 7.31 $(\mathrm{d}, \mathrm{J}=8.4 \mathrm{~Hz}, 2 \mathrm{H}), 6.09$ (s, $1 \mathrm{H}), 3.52(\mathrm{~s}, 2 \mathrm{H}), \mathrm{MS}(\mathrm{ESI}+) \mathrm{m} / \mathrm{z} 237.2(\mathrm{M}+\mathrm{H})^{+}$.

5-((4-(Trifluoromethyl)benzyl)thio)-1,4-dihydropyrazine-2,3-dione (36)

Step A: S-(4-(Trifluoromethyl)benzyl) methanesulfonothioate

To a solution of 4-(trifluoromethyl)benzyl bromide $(0.78 \mathrm{~mL}, 5.00 \mathrm{mmol})$ in dry DMF ( $12 \mathrm{~mL})$ under nitrogen was added sodium methanethiosulfonate $(838 \mathrm{mg}, 6.25 \mathrm{mmol})$ and the reaction mixture was stirred at room temperature for $18 \mathrm{hrs}$. The mixture was diluted with water $(30 \mathrm{~mL})$ and ethyl acetate $(100 \mathrm{~mL})$. The aqueous layer was extracted with ethyl acetate $(2 \times 70 \mathrm{~mL})$ and the combined organic layers were washed with $10 \%$ lithium chloride solution (30 $\mathrm{mL})$ and brine $(40 \mathrm{~mL})$. The organic layer was dried over magnesium sulfate, filtered and concentrated under reduced pressure to yield the title compound as a colorless oil $(1.33 \mathrm{~g}, 98 \%) .{ }^{1} \mathrm{H}$ NMR $\left(\mathrm{CDCl}_{3}, 400 \mathrm{MHz}\right): \delta 7.65(\mathrm{~d}$, $\mathrm{J}=8.2 \mathrm{~Hz}, 2 \mathrm{H}), 7.54(\mathrm{~d}, \mathrm{~J}=8.0 \mathrm{~Hz}, 2 \mathrm{H}), 4.42(\mathrm{~s}, 2 \mathrm{H}), 3.00$ (s, $3 \mathrm{H})$.

Step B: 2,3-Dichloro-5-((4-(trifluoromethyl)benzyl)thio)pyrazine

To a solution of 2,3-dichloropyrazine ( $305 \mathrm{mg}, 2.05 \mathrm{mmol})$ in dry THF ( $2 \mathrm{~mL})$ under nitrogen at room temperature was added dropwise over $10 \mathrm{~min}$. a solution of 2,2,6,6-tetramethylpiperidinylmagnesium chloride lithium chloride complex in THF (1.0 M, $2.3 \mathrm{~mL}, 2.26 \mathrm{mmol})$. The reaction mixture was stirred at room temperature for $30 \mathrm{~min}$. before being cooled to $0{ }^{\circ} \mathrm{C}$. A solution of $S$-(4-(trifluoromethyl)benzyl) methanesulfonothioate $(665 \mathrm{mg}, 2.46$ $\mathrm{mmol})$ in dry THF $(2 \mathrm{~mL})$ was added dropwise over $10 \mathrm{~min}$. The reaction mixture was stirred at $0{ }^{\circ} \mathrm{C}$ for 30 minutes, allowed to warm to room temperature and stirred for $3 \mathrm{hrs}$. Saturated aqueous ammonium chloride solution $(15 \mathrm{~mL})$ was added followed by water $(10 \mathrm{~mL})$. The mixture was extracted with ethyl acetate $(100 \mathrm{~mL}, 20 \mathrm{~mL}, 20$ $\mathrm{mL})$ and the combined organic layers were washed with brine $(20 \mathrm{~mL})$, dried over magnesium sulfate, filtered and concentrated under reduced pressure. The crude material was purified by flash column chromatography (10 - 20\% dichloromethane in cyclohexane) to yield the title compound as a yellow oil (269 mg, 39\%). ${ }^{1} \mathrm{H}$ NMR (400 MHz, $\left.\mathrm{CDCl}_{3}\right): \delta 8.15$ (s, $\left.1 \mathrm{H}\right), 7.60-7.53(\mathrm{~m}, 4 \mathrm{H}), 4.41(\mathrm{~s}, 2 \mathrm{H})$.

Step C: 2,3-Dimethoxy-5-((4-(trifluoromethyl)benzyl)thio)pyrazine 
To a suspension of sodium hydride ( $60 \%$ in mineral oil, $188 \mathrm{mg}, 7.81 \mathrm{mmol})$ in dry dioxane $(3 \mathrm{~mL})$ under nitrogen at room temperature was added dry methanol $(0.32 \mathrm{~mL}, 7.81 \mathrm{mmol})$ dropwise over $10 \mathrm{~min}$. The reaction mixture was stirred at room temperature for 1 hour. A solution of 2,3-dichloro-5-((4-(trifluoromethyl)benzyl)thio)pyrazine (265 mg, $0.781 \mathrm{mmol})$ in dry dioxane $(2 \mathrm{~mL})$ was added over $5 \mathrm{~min}$. and the mixture was stirred at room temperature for $18 \mathrm{hrs}$. Saturated aqueous ammonium chloride solution $(15 \mathrm{~mL})$ was added followed by water $(10$ $\mathrm{mL}$ ). The mixture was extracted with ethyl acetate and the combined organic layers were washed with brine (20 $\mathrm{mL}$ ), dried over magnesium sulfate, filtered and concentrated under reduced pressure. The crude material was purified by flash column chromatography $(10-20 \%$ dichloromethane in cyclohexane) to yield the title compound as a pale-yellow oil (138 mg, 53\%). ${ }^{1} \mathrm{H}$ NMR (400 MHz, $\left.\mathrm{CDCl}_{3}\right)$ : $\delta 7.55-7.51(\mathrm{~m}, 3 \mathrm{H}), 7.43(\mathrm{~d}, \mathrm{~J}=8.0 \mathrm{~Hz}, 2 \mathrm{H}), 4.31$ (s, $2 \mathrm{H}), 4.01$ (s, $3 \mathrm{H}), 3.98$ (s, $3 \mathrm{H}$ ).

Step D: 5-((4-(Trifluoromethyl)benzyl)thio)-1,4-dihydropyrazine-2,3-dione

To a solution of 2,3-dimethoxy-5-((4-(trifluoromethyl)benzyl)thio)pyrazine (138 mg, $0.418 \mathrm{mmol})$ in dioxane (10 $\mathrm{mL}$ ) was added $2 \mathrm{M}$ hydrochloric acid $(10.4 \mathrm{~mL})$ and the mixture was heated at $100{ }^{\circ} \mathrm{C}$ for $4 \mathrm{hrs}$. The mixture was cooled to room temperature and the solvent removed under reduced pressure. The crude material was purified by preparative HPLC to yield the title compound as an off-white (73 mg, 58\%). ${ }^{1} \mathrm{H}$ NMR (400 MHz, DMSO): $\delta 11.43$ (s, 2 H), 7.71-7.67 (m, 2 H), 7.45-7.41 (m, 2 H), 6.12 (s, 1 H), 4.10 (s, 2 H). MS (ESI+) m/z 303 (M+H)+.

The following compounds were synthesized following the same procedure as $\mathbf{3 6}$.

5-((4-Chlorobenzyl)thio)-1,4-dihydropyrazine-2,3-dione (38): ${ }^{1} \mathrm{H}$ NMR (400 MHz, DMSO): $\delta 11.94$ - 11.01 (m, 2 H), 7.37 (d, J = 8.4 Hz, 2 H), 7.23 (d, J = 8.4 Hz, 2 H), 6.12 (s, 1 H), 4.01 (s, 2 H). MS (ESI+) m/z 269 (M+H) ${ }^{+}$ 4-(((5,6-Dioxo-1,4,5,6-tetrahydropyrazin-2-yl)thio)methyl)-benzonitrile (40): ${ }^{1} \mathrm{H}$ NMR (400 MHz, DMSO) $\delta 11.72$ 11.03 (m, 2 H), 7.79 (d, J = 8.3 Hz, 2 H), 7.40 (d, J = 8.4 Hz, 2 H), 6.09 (s, 1 H), 4.09 (s, 2 H). MS (ESI+) m/z 260 $(\mathrm{M}+\mathrm{H})^{+}$.

5-((4-(Difluoromethyl)-benzyl)thio)-1,4-dihydropyrazine-2,3-dione (41): ${ }^{1} \mathrm{H}$ NMR (400 MHz, DMSO): $\delta 11.62$ (s, 1 H), 11.21 (s, 1 H), 7.50 (d, J = 7.9 Hz, 2 H), 7.34 (d, J = 7.9 Hz, 2 H), 7.00 (t, J = 55.8 Hz, 1 H), 6.10 (s, 1 H), 4.06 (s, 2 H). MS (ESI+) m/z $285(\mathrm{M}+\mathrm{H})^{+}$.

5-((4-(Methylsulfonyl)-benzyl)thio)-1,4-dihydropyrazine-2,3-dione (43): ${ }^{1} \mathrm{H}$ NMR (400 MHz, DMSO): $\delta 11.42-$ 11.25 (m, 2 H), 7.87 (d, J = 8.5 Hz, 2 H), 7.48 (d, J = 8.4 Hz, 2 H), 6.14 (s, 1 H), 4.12 (s, 2 H), 3.20 (s, 3 H). MS (ESI+) $\mathrm{m} / \mathrm{z} 313(\mathrm{M}+\mathrm{H})^{+}$.

5-(((6-(Trifluoromethyl)-pyridin-3-yl)methyl)thio)-1,4-dihydropyrazine-2,3-dione (48): ${ }^{1} \mathrm{H}$ NMR (400 MHz, DMSO): $\delta 11.60$ (s, $1 \mathrm{H}), 11.29$ (s, $1 \mathrm{H}), 8.65$ (s, $1 \mathrm{H}), 7.93-7.89$ (m, $2 \mathrm{H}), 6.21$ (s, $1 \mathrm{H}), 4.18-4.17$ (m, $2 \mathrm{H})$. MS (ESI+) $\mathrm{m} / \mathrm{z} 304(\mathrm{M}+\mathrm{H})^{+}$.

3-(((5,6-Dioxo-1,4,5,6-tetrahydro pyrazin-2-yl)thio) methyl)-benzonitrile (47): The hydrolysis step was carried out with sodium iodide and TMSCl conditions. ${ }^{1} \mathrm{H}$ NMR (400 MHz, DMSO): $\delta 11.41$ (s, 2 H), 7.75-7.70 (m, 2 H), 7.547.52 (m, 2 H), 6.14 (s, 1 H), 4.07-4.05 (m, 2 H). MS (ESI+) m/z $260(\mathrm{M}+\mathrm{H})^{+}$.

5-((3,4-Difluorobenzyl)thio)-1,4-dihydropyrazine-2,3-dione (49)

Step A: 2-((3,4-Difluorobenzyl)thio)-6-methoxypyrazine 
To a solution of 3,4-difluorobenzyl mercaptan $(665 \mathrm{mg}, 4.15 \mathrm{mmol})$ in dry acetonitrile $(8 \mathrm{~mL})$ under nitrogen was added sodium tert-butoxide $(997 \mathrm{mg}, 10.38 \mathrm{mmol}$ ). The mixture was stirred at room temperature for $5 \mathrm{~min}$. A solution of 2-chloro-6-methoxypyrazine $(500 \mathrm{mg}, 3.46 \mathrm{mmol})$ was added and the mixture was heated at $85{ }^{\circ} \mathrm{C}$ for 90 min. The reaction mixture was cooled to room temperature, diluted with water $(20 \mathrm{~mL})$ and extracted with ethyl acetate $(2 \times 30 \mathrm{~mL})$. The combined organic layers were washed with brine $(20 \mathrm{~mL})$, passed through a phase separation and concentrated under reduced pressure. The crude material was purified by flash column chromatography (15\% ethyl acetate in cyclohexane) to yield the title compound as a red oil (708 $\mathrm{mg}, 76 \%) .{ }^{1} \mathrm{H}$ NMR (400 MHz, CDCl $): \delta 8.02$ (s, 1 H), 7.90 (s, 1 H), 7.26-7.20 (m, 1 H), 7.12-7.06 (m, 2 H), 4.35 (s, 2 H), 3.95 (s, $3 \mathrm{H})$.

Step B: 2-Bromo-5-((3,4-difluorobenzyl)thio)-3-methoxypyrazine To a solution of 2-((3,4-difluorobenzyl)thio)-6-methoxypyrazine (400 $\mathrm{mg}, 1.50 \mathrm{mmol})$ in dry dichloromethane (8 $\mathrm{mL}$ ) under nitrogen cooled to $0{ }^{\circ} \mathrm{C}$ was added $N$-bromosuccinimide (290 $\mathrm{mg}, 1.65 \mathrm{mmol}$ ). The reaction mixture was stirred at $0{ }^{\circ} \mathrm{C}$ for 2 hours, warmed to room temperature and stirred for $18 \mathrm{hrs}$. The reaction mixture was diluted with saturated sodium hydrogencarbonate solution $(20 \mathrm{~mL})$ and extracted with dichloromethane $(2 \times 50 \mathrm{~mL})$. The combined organic layers were dried over magnesium sulfate, filtered and concentrated under reduced pressure. The crude material was purified by flash column chromatography (0-80\% dichloromethane in cyclohexane) to yield the title compound as a yellow oil (350 mg, 67\%). ${ }^{1} \mathrm{H}$ NMR (400 MHz, $\left.\mathrm{CDCl}_{3}\right): \delta 7.83(\mathrm{~s}, 1 \mathrm{H}), 7.25-7.18(\mathrm{~m}, 1 \mathrm{H})$, 7.15-7.06 (m, $2 \mathrm{H}), 4.32$ (s, $2 \mathrm{H}), 4.02$ (s, $3 \mathrm{H})$.

Step C: 5-((3,4-Difluorobenzyl)thio)-1,4-dihydropyrazine-2,3-dione

Following steps C-D from compound $\mathbf{3 6}$ used to prepare 5-((4-(trifluoromethyl)benzyl)thio)-1,4-dihydropyrazine-2,3dione yielded the title compound as an off-white solid (37 mg, 13\% over two steps). ${ }^{1} \mathrm{H}$ NMR (400 MHz, DMSO): $\delta$ $11.32(\mathrm{~d}, \mathrm{~J}=115.6 \mathrm{~Hz}, 2 \mathrm{H}), 7.33-7.21$ (m, $2 \mathrm{H}), 6.97-6.94$ (m, $1 \mathrm{H}), 6.10-6.08$ (m, $1 \mathrm{H}), 3.91$ (s, $2 \mathrm{H})$. MS (ESI+) $\mathrm{m} / \mathrm{z} 271(\mathrm{M}+\mathrm{H})^{+}$.

5-((4-(Pentafluoro- $\lambda^{6}$-sulfaneyl)benzyl)thio)-1,4-dihydropyrazine-2,3-dione (45) was prepared following the procedure used to prepare 49 yielded after purification by preparative HPLC the title compound as an off-white solid (4.6 mg, $2 \%$ over four steps). ${ }^{1} \mathrm{H}$ NMR (400 MHz, DMSO): $\delta$ 11.40-11.33 (m, $2 \mathrm{H}$ ), 7.91-7.88 (m, $\left.2 \mathrm{H}\right)$, 7.50-7.45 (m, 2 H), 6.19 (s, 1 H), 4.14-4.13 (m, 2 H). MS (ESI+) m/z $361(\mathrm{M}+\mathrm{H})^{+}$.

4-(((5,6-Dioxo-1,4,5,6-tetrahydropyrazin-2-yl)thio)methyl)-2-fluorobenzonitrile (50)

Step A: 5-((3-Bromobenzyl)thio)-2,3-dimethoxypyrazine

Following steps A-C from compound $\mathbf{3 6}$ used to prepare 5-((4-(trifluoromethyl)benzyl)thio)-1,4-dihydropyrazine2,3-dione yielded the title compound as a brown oil (32\% over three steps). ${ }^{1} \mathrm{H}$ NMR (400 MHz, $\left.\mathrm{CDCl}_{3}\right): \delta, 7.55$ (s, 1 H), 7.45-7.41 (m, 1 H), 7.14-6.97 (m, 2 H), 4.22-4.21 (m, 2 H), 4.01 (s, 3 H), 3.98 (s, 3 H).

Step B: 4-(((5,6-Dimethoxypyrazin-2-yl)thio)methyl)-2-fluorobenzonitrile To a degassed solution of 5-((3-bromobenzyl)thio)-2,3-dimethoxypyrazine (300 $\mathrm{mg}, 0.835 \mathrm{mmol})$ in dry butanol (4 $\mathrm{mL}$ ) was added DIPEA (0.29 mL, $1.67 \mathrm{mmol}$ ), Pd(pi-cinnamyl) chloride dimer (43 mg, $0.0835 \mathrm{mmol}$ ) and X-Phos (119 mg, $0.251 \mathrm{mmol})$. The mixture was heated at $80{ }^{\circ} \mathrm{C}$ under nitrogen before a solution of acetone cyanohydrin 
$(0.092 \mathrm{~mL}, 1.0 \mathrm{mmol})$ in dry butanol $(1 \mathrm{~mL})$ was added dropwise over $90 \mathrm{~min}$. The mixture was cooled to room temperature and saturated sodium hydrogen carbonate solution $(10 \mathrm{~mL})$ was added. The mixture was extracted with ethyl acetate $(3 \times 20 \mathrm{~mL})$ and the combined organic layers were washed with brine $(10 \mathrm{~mL})$, dried over sodium sulfate, filtered and concentrated under reduced pressure. The crude material was purified by flash column chromatography $(0-30 \%$ ethyl acetate in cyclohexane) to yield the title compound as a pale-yellow oil (140 mg, 55\%). ${ }^{1} \mathrm{H}$ NMR (400 MHz, $\left.\mathrm{CDCl}_{3}\right): \delta 7.55-7.43(\mathrm{~m}, 2 \mathrm{H}), 7.39-7.29(\mathrm{~m}, 2 \mathrm{H}), 5.56$ (s, $\left.2 \mathrm{H}\right), 5.51$ (s, $\left.3 \mathrm{H}\right), 5.46(\mathrm{~s}, 3$ $\mathrm{H})$.

Step C: 4-(((5,6-Dioxo-1,4,5,6-tetrahydropyrazin-2-yl)thio)methyl)-2-fluorobenzonitrile 4-(((5,6-Dimethoxypyrazin-2-yl)thio)methyl)-2-fluorobenzonitrile was hydrolyzed with NaI and TMSCl to afford the title compound after purification by preparative HPLC as an off-white solid (61 mg, 48\%). ${ }^{1} \mathrm{H} \mathrm{NMR}(400 \mathrm{MHz}$, DMSO): $\delta$ 11.80-11.05 (m, 2 H), 7.87 (dd, J = 7.5, $7.5 \mathrm{~Hz}, 1 \mathrm{H}), 7.42$ (dd, J = 1.2, 10.5 Hz, $1 \mathrm{H}), 7.23$ (dd, J = 1.4, $8.0 \mathrm{~Hz}, 1 \mathrm{H}), 6.17(\mathrm{~s}, 1 \mathrm{H}), 4.08(\mathrm{~s}, 2 \mathrm{H}) . \mathrm{MS}(\mathrm{ESI}+) \mathrm{m} / \mathrm{z} 278(\mathrm{M}+\mathrm{H})^{+}$.

5-(((4-(Trifluoromethyl)phenyl)thio)methyl)-1,4-dihydropyrazine-2,3-dione (37)

Step A: (5,6-Dimethoxypyrazin-2-yl)methanol

To 5-bromo-2,3-dimethoxypyrazine $(2.0 \mathrm{~g}, 9.1 \mathrm{mmol})$ in THF $(25 \mathrm{~mL})$ at $-70{ }^{\circ} \mathrm{C}$ was added $n$-butyl lithium $(4.0 \mathrm{~mL}$, $2.5 \mathrm{M}$ solution in THF, $10.0 \mathrm{mmol})$ over $15 \mathrm{~min}$. The reaction was stirred at $-70{ }^{\circ} \mathrm{C}$ for 1 hour and $\mathrm{DMF}(1.4 \mathrm{~mL}$, $18.3 \mathrm{mmol}$ ) was then added over $5 \mathrm{~min}$. at $-70^{\circ} \mathrm{C}$. The reaction was stirred at $-70{ }^{\circ} \mathrm{C}$ for $1.5 \mathrm{hrs}$. Methanol $(10 \mathrm{~mL})$ and sodium borohydride $(690 \mathrm{mg}, 18.3 \mathrm{mmol})$ were added and the reaction was stirred for $0.5 \mathrm{hrs}$. The reaction was brought to $-20{ }^{\circ} \mathrm{C}$ and quenched with saturated ammonium chloride solution $(10 \mathrm{~mL})$. The reaction was diluted with ethyl acetate $(20 \mathrm{~mL})$. The organics were separated and the aqueous further extracted with ethyl acetate $(2 \mathrm{x} 20 \mathrm{~mL})$. The combined organics were washed with brine, dried over sodium sulfate, filtered and concentrated under reduced pressure. The crude material was purified by flash column chromatography $(0-50 \%$ ethyl acetate in ether) to yield the title compound as a pale-yellow solid $(1.31 \mathrm{~g}, 84 \%) .{ }^{1} \mathrm{H}$ NMR $\left(400 \mathrm{MHz}, \mathrm{CDCl}_{3}\right): \delta 7.62(\mathrm{~d}, \mathrm{~J}=0.8 \mathrm{~Hz}, 1 \mathrm{H})$, $4.63(\mathrm{~d}, \mathrm{~J}=0.8 \mathrm{~Hz}, 2 \mathrm{H}), 4.04$ (s, $3 \mathrm{H}), 4.02$ (s, $3 \mathrm{H}), 2.41$ (m, $1 \mathrm{H})$.

Step B: 5-(Bromomethyl)-2,3-dimethoxypyrazine

To (5,6-dimethoxypyrazin-2-yl)methanol (6.2 g, $36.7 \mathrm{mmol})$ was added triphenylphosphine (9.6 g, $36.7 \mathrm{mmol}) \mathrm{in}$ dichloromethane at $0{ }^{\circ} \mathrm{C}$. Carbon tetrabromide $(12.2 \mathrm{~g}, 36.7 \mathrm{mmol})$ was added. The reaction was stirred at room temperature for $48 \mathrm{hrs}$. The reaction was concentrated under reduced pressure. The crude material was purified by flash column chromatography $(0-20 \%$ ethyl acetate in cyclohexane) to yield the title compound as a colorless solid (7.06 g, 82\%). ${ }^{1} \mathrm{H}$ NMR (400 MHz, $\mathrm{CDCl}_{3}$ ): $\delta 7.69$ (s, $\left.1 \mathrm{H}\right), 4.45$ (s, $\left.2 \mathrm{H}\right), 4.04$ (s, $\left.3 \mathrm{H}\right), 4.02$ (s, $\left.3 \mathrm{H}\right)$.

Step C: 2,3-Dimethoxy-5-(((4-(trifluoromethyl)phenyl)thio)methyl)pyrazine

To 4-(trifluoromethyl)thiophenol (3.36 g, $18.8 \mathrm{mmol})$ was added cesium carbonate $(6.15 \mathrm{~g}, 18.8 \mathrm{mmol})$ and tetrabutylammonium iodide $(6.97 \mathrm{~g}, 18.8 \mathrm{mmol})$ in DMF $(85 \mathrm{~mL})$, the reaction was stirred at room temperature for 1 hour. 5-(Bromomethyl)-2-3-dimethoxypyrazine (4.00 g, $17.1 \mathrm{mmol}$ ) was added and the reaction was stirred at room temperature for $24 \mathrm{hrs}$. The reaction was diluted with ethyl acetate $(40 \mathrm{~mL})$ and water $(40 \mathrm{~mL})$. The organics were separated and the aqueous further extracted with ethyl acetate $(2 \times 40 \mathrm{~mL})$. The combined organics were washed with brine $(20 \mathrm{~mL})$, dried over sodium sulfate, filtered and concentrated under reduced pressure. The crude material 
was purified by flash column chromatography ( $0-25 \%$ ethyl acetate in cyclohexane) to yield the title compound as an off-white solid (5.62 g, 99\%). ${ }^{1} \mathrm{H}$ NMR (400 MHz, $\mathrm{CDCl}_{3}$ ): $\delta$ 7.59-7.58 (m, $\left.1 \mathrm{H}\right), 7.52-7.44(\mathrm{~m}, 4 \mathrm{H}), 4.15$ (s, 2 H), 3.97 (d, J = $13.9 \mathrm{~Hz}, 6 \mathrm{H})$.

Step D: 5-(((4-(Trifluoromethyl)phenyl)thio)methyl)-1,4-dihydropyrazine-2,3-dione

2,3-Dimethoxy-5-(((4-(trifluoromethyl)phenyl)thio)methyl)pyrazine (5.60 g, $16.9 \mathrm{mmol})$ was dissolved in 1,4dioxane $(170 \mathrm{~mL})$ and $2 \mathrm{M} \mathrm{HCl}(169.0 \mathrm{~mL}, 339.0 \mathrm{mmol})$ was added. The reaction was heated at $100{ }^{\circ} \mathrm{C}$ for $24 \mathrm{hrs}$ under nitrogen. The reaction was cooled to room temperature and concentrated under reduced pressure. The crude material was purified by flash column chromatography $(0-20 \% \mathrm{MeOH}$ in dichloromethane), yielding the title compound as a white solid (2.82 g, 55\%). ${ }^{1} \mathrm{H}$ NMR (400 MHz, DMSO): $\delta 11.38$ (s, $\left.1 \mathrm{H}\right), 11.07$ (d, J = 4.5 Hz, $1 \mathrm{H}$ ), 7.69-7.65 (m, 2 H), 7.60-7.56 (m, 2 H), 6.25 (d, J = 4.0 Hz, 1 H), 3.96 (s, 2 H). MS (ESI+) m/z $303(M+H)^{+}$.

The following compounds were prepared following the same procedure as compound $\mathbf{3 7}$. 5-(((4-Chlorophenyl)thio)methyl)-1,4-dihydropyrazine-2,3-dione (39): ${ }^{1} \mathrm{H}$ NMR (400 MHz, DMSO): $\delta$ 11.27-11.04 (m, 2 H), 7.38 (s, 4 H), 6.05 (s, 1 H), 3.80 (s, 2 H). $\quad$ MS (ES+) m/z $269(\mathrm{M}+\mathrm{H})^{+}$ 5-(((4-(Methylsulfonyl)phenyl)thio)methyl)-1,4-dihydropyrazine-2,3-dione (44): ${ }^{1} \mathrm{H}$ NMR (400 MHz, DMSO): $\delta$ 11.21-11.20 (m, 2 H), 7.83-7.80 (m, 2 H), 7.61-7.58 (m, 2 H), 6.30 (s, 1 H), 3.98 (s, 2 H), 3.20 (s, 3 H). MS (ES+) $\mathrm{m} / \mathrm{z} 313(\mathrm{M}+\mathrm{H})^{+}$.

5-(((4-(Pentafluoro- $\lambda 6$-sulfaneyl)phenyl)thio)methyl)-1,4-dihydropyrazine-2,3-dione (46)

Step A: Triisopropyl((4-(pentafluoro- $\lambda 6$-sulfaneyl)phenyl)thio)silane

To 1-bromo-4-(pentafluorosulfanyl)benzene $(132 \mathrm{mg}, 0.4 \mathrm{mmol})$ was added triisopropylsilanethiol $(0.10 \mathrm{~mL}, 0.5$ $\mathrm{mmol})$ and lithium bis(trimethylsilyl)amide $(0.51 \mathrm{~mL}, 0.5 \mathrm{mmol})$ in toluene $(2.5 \mathrm{~mL})$. The reaction was degassed for $5 \mathrm{~min}$. and [1,1'-bis(diphenylphosphino)ferrocene]dichloroPd(II) complex with dichloromethane (38 mg, 0.05 mmol) was added and the reaction was stirred at $110^{\circ} \mathrm{C}$ for $2 \mathrm{hrs}$. The mixture was cooled to room temperature and concentrated under reduced pressure. The crude material was purified by flash column chromatography $(0-10 \%$ dichloromethane in cyclohexane) to yield the title compound as an orange oil (180 mg, 98\%). ${ }^{1} \mathrm{H} \mathrm{NMR} \mathrm{(400} \mathrm{MHz,}$ $\mathrm{CDCl}_{3}$ ): $\delta$ 7.57-7.55 (m, $\left.4 \mathrm{H}\right), 1.31-1.23$ (m, $\left.3 \mathrm{H}\right), 1.10-1.08$ (m, $\left.18 \mathrm{H}\right)$.

Step B: 2,3-Dimethoxy-5-(((4-(pentafluoro- $\lambda 6$-sulfaneyl)phenyl)thio)methyl)pyrazine To triisopropyl((4-(pentafluoro- $\lambda 6$-sulfaneyl)phenyl)thio)silane (180 mg, $0.5 \mathrm{mmol}$ ) was added 5-(bromomethyl)-23-dimethoxypyrazine (128 mg, $0.6 \mathrm{mmol}$ ) (prepared following steps A-B, compound 37), cesium fluoride (139 mg, $0.9 \mathrm{mmol})$ and cesium carbonate $(74 \mathrm{mg}, 0.23 \mathrm{mmol})$ in $\mathrm{DMF}(2.5 \mathrm{~mL})$ and the reaction was stirred at $50{ }^{\circ} \mathrm{C}$ for 1.5 hrs. The reaction was diluted with ethyl acetate $(5 \mathrm{~mL})$ and water $(5 \mathrm{~mL})$. The organics were separated and the aqueous further extracted with ethyl acetate $(2 \times 5 \mathrm{~mL})$. The combined organics were washed with brine, dried over sodium sulfate, filtered and concentrated under reduced pressure. The crude material was purified by flash column chromatography ( $0-20 \%$ ethyl acetate in cyclohexane) to yield the title compound as a pale-yellow oil (160 mg, 92\%). ${ }^{1} \mathrm{H}$ NMR (400 MHz, $\left.\mathrm{CDCl}_{3}\right): \delta 7.64$ (s, $\left.1 \mathrm{H}\right), 7.61$ (d, J = 6.2 Hz, $\left.2 \mathrm{H}\right), 7.45-7.41$ (m, $\left.2 \mathrm{H}\right), 4.16-4.15$ (s, $2 \mathrm{H}$ ), 4.00 (s, $3 \mathrm{H}), 3.95$ (s, $3 \mathrm{H})$.

Step C: 5-(((4-(Pentafluoro- $\lambda 6$-sulfaneyl)phenyl)thio)methyl)-1,4-dihydropyrazine-2,3-dione 
To 2,3-dimethoxy-5-(((4-(pentafluoro- $\lambda 6$-sulfaneyl)phenyl)thio)methyl)pyrazine (155 $\mathrm{mg}, 0.4 \mathrm{mmol}$ ) was added sodium iodide $(299 \mathrm{mg}, 2.0 \mathrm{mmol})$ and chlorotrimethylsilane $(0.25 \mathrm{~mL}, 2.0 \mathrm{mmol})$ in acetonitrile $(4 \mathrm{~mL})$ and the reaction was heated at $60{ }^{\circ} \mathrm{C}$ for 1 hour. The reaction was cooled to room temperature and concentrated under reduced pressure. The crude material was purified by reverse phase preparative HPLC to yield the title compound as a white solid (21 mg, 15\%). ${ }^{1} \mathrm{H}$ NMR (400 MHz, DMSO): $\delta$ 11.29-11.28 (m, $\left.1 \mathrm{H}\right), 11.00-10.96$ (m, $\left.1 \mathrm{H}\right)$, 7.76-7.71 (m, 2 H), 7.52-7.46 (m, 2 H), 6.21 (s, 1 H), 3.25 (s, 2 H). MS (ES+) m/z $361(\mathrm{M}+\mathrm{H})^{+}$.

The following compounds were prepared following the same procedure as compound $\mathbf{4 6}$. 5-(((4-(Difluoromethyl)phenyl)thio)methyl)-1,4-dihydropyrazine-2,3-dione (42): ${ }^{1} \mathrm{H}$ NMR (400 MHz, DMSO): $\delta$ 11.26 (s, 2 H), 7.56-7.54 (m, 4 H), 7.0 (t, 1 H), 6.27-6.25 (m, 1 H), 3.95-3.94 (m, 2 H). MS (ES+) m/z $285(\mathrm{M}+\mathrm{H})^{+}$. 5-(((7-chloroquinolin-3-yl)thio)methyl)-1,4-dihydropyrazine-2,3-dione (53): ${ }^{1} \mathrm{H}$ NMR (400 MHz, DMSO): $\delta 11.41$ 11.40 (m, 1 H), 10.98-10.93 (m, 1 H), 8.87 (d, J = 2.3 Hz, 1 H), 8.46 (d, J = 2.1 Hz, 1 H), 8.08-8.00 (m, 2 H), 7.69 $(\mathrm{dd}, \mathrm{J}=2.1,8.8 \mathrm{~Hz}, 1 \mathrm{H}), 6.10(\mathrm{dd}, \mathrm{J}=2.3,5.5 \mathrm{~Hz}, 1 \mathrm{H}), 3.95-3.94(\mathrm{~m}, 2 \mathrm{H}) . \mathrm{MS}(\mathrm{ES}+) \mathrm{m} / \mathrm{z} 320(\mathrm{M}+\mathrm{H})^{+}$.

4-(((5,6-Dioxo-1,4,5,6-tetrahydropyrazin-2-yl)methyl)thio)-2-fluorobenzonitrile (51)

Step A: O-(4-Cyano-3-fluorophenyl) dimethylcarbamothioate

To 2-fluoro-4-hydroxybenzonitrile ( $1.00 \mathrm{~g}, 7.2 \mathrm{mmol})$ was added dimethylthiocarbamoyl (1.08 g, $8.7 \mathrm{mmol})$, 4dimethylaminopyridine $(0.09 \mathrm{~g}, 0.7 \mathrm{mmol})$ and trimethylamine $(3.0 \mathrm{~mL}, 21.8 \mathrm{mmol})$ in dichloromethane $(20 \mathrm{~mL})$ and the reaction was stirred at $40{ }^{\circ} \mathrm{C}$ for $24 \mathrm{hrs}$. The reaction was cooled to room temperature and diluted with dichloromethane $(20 \mathrm{~mL})$ and water $(20 \mathrm{~mL})$. The aqueous layer was separated and further extracted with dichloromethane $(2 \times 20 \mathrm{~mL})$. The combined organics were passed through a phase separator and concentrated under reduced pressure. The crude solid was triturated with cyclohexane to give a white solid $(1.64 \mathrm{~g}, 100 \%) .{ }^{1} \mathrm{H}$ NMR (400 MHz, $\mathrm{CDCl}_{3}$ ): $\delta$ 7.68-7.60 (m, $\left.1 \mathrm{H}\right), 7.02-6.98$ (m, 2 H), 3.45 (s, 3 H), 3.35 (s, $3 \mathrm{H}$ ).

Step B: S-(4-Cyano-3-fluorophenyl) dimethylcarbamothioate $O$-(4-Cyano-3-fluorophenyl) dimethylcarbamothioate $(1.64 \mathrm{~g}, 7.3 \mathrm{mmol})$ was melted and stirred at $210{ }^{\circ} \mathrm{C}$ for $6 \mathrm{hrs}$. The reaction was cooled to room temperature. The crude material was purified by flash column chromatography $(0-$ $50 \%$ ethyl acetate in cyclohexane) to yield the title compound (0.92 g, 56\%). ${ }^{1} \mathrm{H} \mathrm{NMR}\left(400 \mathrm{MHz}, \mathrm{CDCl}_{3}\right): \delta 7.64-$ 7.56 (m, $1 \mathrm{H}), 7.47-7.36$ (m, $2 \mathrm{H}), 3.10$ (s, $6 \mathrm{H})$.

Step C: 2-Fluoro-4-mercaptobenzonitrile $S$-(4-Cyano-3-fluorophenyl) dimethylcarbamothioate $(0.50 \mathrm{~g}, 2.2 \mathrm{mmol})$ was dissolved in THF $(5.7 \mathrm{~mL})$ and potassium hydroxide $(0.23 \mathrm{~g}, 4.1 \mathrm{mmol})$ and methanol $(7.7 \mathrm{~mL})$ were added. The reaction was stirred at room temperature for $24 \mathrm{hrs}$. The mixture was concentrated under reduced pressure then diluted with ethyl acetate (10 $\mathrm{mL})$ and $2 \mathrm{M}$ hydrogen chloride $(10 \mathrm{~mL})$. The organics were separated and the aqueous further extracted with ethyl acetate $(2 \times 10 \mathrm{~mL})$. The combined organics were dried over magnesium sulfate, filtered and concentrated under reduced pressure to yield the title compound $(0.34 \mathrm{~g}, 100 \%)$. ${ }^{1} \mathrm{H}$ NMR $\left(400 \mathrm{MHz}, \mathrm{CDCl}_{3}\right): \delta 7.49-7.41(\mathrm{~m}, 2 \mathrm{H})$, 7.12-7.07 (m, $1 \mathrm{H}), 2.93-2.88$ (m, $1 \mathrm{H})$.

Step D: 4-(((5,6-Dimethoxypyrazin-2-yl)methyl)thio)-2-fluorobenzonitrile 
To 2-fluoro-4-mercaptobenzonitrile $(0.10 \mathrm{~g}, 0.7 \mathrm{mmol})$ was added cesium carbonate $(0.23 \mathrm{~g}, 0.7 \mathrm{mmol})$ and tetrabutylammonium iodide $(0.261 \mathrm{~g}, 0.7 \mathrm{mmol})$ in DMF $(3.5 \mathrm{~mL})$ and the reaction was stirred at room temperature for 1 hour. 5-(Bromomethyl)-2-3-dimethoxypyrazine $(0.15 \mathrm{~g}, 0.6 \mathrm{mmol})$ was added at $0{ }^{\circ} \mathrm{C}$ and stirred at room temperature for 1 hour. The reaction was diluted with ethyl acetate $(5 \mathrm{~mL})$ and water $(5 \mathrm{~mL})$. The aqueous was separated and further extracted with ethyl acetate $(2 \times 5 \mathrm{~mL})$. The combined organics were passed through a phase separator cartridge and concentrated under reduced pressure. The crude material was purified by flash column chromatography ( 0 - 20\% ethyl acetate in cyclohexane, $12 \mathrm{~g}$ column) to yield the title compound as a white solid (0.135 g, 69\%). ${ }^{1} \mathrm{H}$ NMR (400 MHz, $\left.\mathrm{CDCl}_{3}\right): \delta 7.64$ (s, $\left.1 \mathrm{H}\right), 7.49-7.44(\mathrm{~m}, 1 \mathrm{H}), 7.38-7.33(\mathrm{~m}, 1 \mathrm{H}), 7.19(\mathrm{dd}, \mathrm{J}=$ 1.3, 8.3 Hz, $1 \mathrm{H}), 4.18$ (s, $2 \mathrm{H}), 4.01-3.98$ (m, $6 \mathrm{H})$.

Step E: 4-(((5,6-Dioxo-1,4,5,6-tetrahydropyrazin-2-yl)methyl)thio)-2-fluorobenzonitrile

To 4-(((5,6-dimethoxypyrazin-2-yl)methyl)thio)-2-fluorobenzonitrile (130 $\mathrm{mg}, 0.4 \mathrm{mmol})$ was added sodium iodide $(320 \mathrm{~g}, 2.1 \mathrm{mmol})$ and chlorotrimethylsilane $(0.27 \mathrm{~mL}, 2.1 \mathrm{mmol})$ in acetonitrile $(4.5 \mathrm{~mL})$ and the reaction was heated at $60{ }^{\circ} \mathrm{C}$ for $2 \mathrm{hrs}$. The mixture was cooled to room temperature and concentrated under reduced pressure onto silica. The crude material was purified by flash column chromatography $(0-20 \% \mathrm{MeOH}$ in dichloromethane) and then further purified by preparative HPLC to yield the title compound as a white solid (81 $\mathrm{mg}, 67 \%)$. ${ }^{1} \mathrm{H}$ NMR (400 MHz, DMSO): $\delta 11.27$ - 11.27 (m, 2 H), 7.87 (t, J=7.7 Hz, 1 H), 7.65 (dd, J=1.3, 10.7 Hz, 1 H), 7.41 (dd, $\mathrm{J}=1.3,8.3 \mathrm{~Hz}, 1 \mathrm{H}), 6.43(\mathrm{~s}, 1 \mathrm{H}), 4.07$ (s, $2 \mathrm{H}) . \mathrm{MS}(\mathrm{ESI}+) \mathrm{m} / \mathrm{z} 278.1(\mathrm{M}+\mathrm{H})^{+}$.

2-Chloro-4-(((5,6-dioxo-1,4,5,6-tetrahydropyrazin-2-yl)methyl)thio)benzonitrile (52)

Step A: 2-Chloro-4-mercaptobenzonitrile

To 2-chloro-4-fluorobenzonitrile $(0.50 \mathrm{~g}, 3.2 \mathrm{mmol})$ was added sodium sulphide $(0.27 \mathrm{~g}, 3.5 \mathrm{mmol})$ and in DMF $(2.5 \mathrm{~mL})$ and the reaction was stirred at room temperature for $2 \mathrm{hrs}$. $1 \mathrm{M}$ Sodium hydroxide was added and the mixture washed with dichloromethane $(5 \mathrm{~mL})$. The aqueous layer was acidified to $\mathrm{pH} 1-2$ with $1 \mathrm{M}$ hydrogen chloride solution $(2 \mathrm{~mL})$ and extracted with dichloromethane $(2 \times 5 \mathrm{~mL})$. The combined organic layers were washed with brine $(5 \mathrm{~mL})$, dried over magnesium sulfate, filtered and concentrated under reduced pressure to provide a crude residue. To the residue was added $10 \%$ hydrogen chloride solution $(2 \mathrm{~mL})$ and the mixture was cooled with an ice-water bath. Zinc dust (2.00 g, $30.6 \mathrm{mmol})$ was added and the mixture was stirred for 1 hour. Ethyl acetate (5 $\mathrm{mL}$ ) was added and the mixture was stirred for an additional $30 \mathrm{~min}$. The organic layer was separated and washed with water $(10 \mathrm{~mL})$ and brine $(10 \mathrm{~mL})$, dried over magnesium sulfate, filtered and concentrated under reduced pressure to provide the desired product as an orange oil $(0.48 \mathrm{~g}, 88 \%)$. ${ }^{1} \mathrm{H}$ NMR $\left(400 \mathrm{MHz}, \mathrm{CDCl}_{3}\right): \delta 7.52-7.46(\mathrm{~m}$, $1 \mathrm{H}), 7.40-7.36(\mathrm{~m}, 1 \mathrm{H}), 7.26$ (s, $1 \mathrm{H}), 3.74$ (s, $1 \mathrm{H})$.

Step B: 4-(((5,6-Dimethoxypyrazin-2-yl)methyl)thio)phthalonitrile

To 2-chloro-4-mercaptobenzonitrile $(0.08 \mathrm{~g}, 0.4 \mathrm{mmol})$ was added cesium carbonate $(0.15 \mathrm{~g}, 0.4 \mathrm{mmol})$ and tetrabutylammonium iodide $(0.17 \mathrm{~g}, 0.4 \mathrm{mmol})$ in $\mathrm{DMF}(2.5 \mathrm{~mL})$ and the reaction was stirred at room temperature for 1 hour. 5-(Bromomethyl)-2-3-dimethoxypyrazine $(0.10 \mathrm{~g}, 0.4 \mathrm{mmol})$ was added at $0{ }^{\circ} \mathrm{C}$ and the mixture was stirred at room temperature for 1 hour. The reaction was diluted with dichloromethane $(5 \mathrm{~mL})$ and water $(5 \mathrm{~mL})$. The organics were separated and the aqueous was extracted with dichloromethane $(2 \times 10 \mathrm{~mL})$. The combined organics were passed through a phase separator and concentrated under reduced pressure. The crude material was 
purified by flash column chromatography ( $0-30 \%$ ethyl acetate in cyclohexane) to yield the title compound as an off-white solid (0.14 g, 98\%). ${ }^{1} \mathrm{H}$ NMR (400 MHz, $\mathrm{CDCl}_{3}$ ): $\delta 7.63$ (d, J = 6.1 Hz, $\left.2 \mathrm{H}\right), 7.53-7.48(\mathrm{~m}, 1 \mathrm{H})$, 7.29$7.27(\mathrm{~m}, 1 \mathrm{H}), 4.18(\mathrm{~s}, 2 \mathrm{H}), 4.01-3.98(\mathrm{~m}, 6 \mathrm{H})$.

Step C: 2-Chloro-4-(((5,6-dioxo-1,4,5,6-tetrahydropyrazin-2-yl)methyl)thio)benzonitrile

To 4-(((5,6-dimethoxypyrazin-2-yl)methyl)thio)phthalonitrile $(0.13 \mathrm{~g}, 0.4 \mathrm{mmol})$ was added sodium iodide $(0.30 \mathrm{~g}$, $2.0 \mathrm{mmol})$ and chlorotrimethylsilane $(0.22 \mathrm{~g}, 2.0 \mathrm{mmol})$ in acetonitrile $(4.0 \mathrm{~mL})$ and the reaction was heated at $60{ }^{\circ} \mathrm{C}$ for 1 hour. The mixture was cooled to room temperature and concentrated under reduced pressure onto silica gel. The crude material was purified by flash column chromatography $(0-20 \% \mathrm{MeOH}$ in dichloromethane) to yield the title compound (53 mg, 45\%). ${ }^{1} \mathrm{H}$ NMR (400 MHz, DMSO): $\delta 11.43-11.38(\mathrm{~m}, 1 \mathrm{H}), 11.14(\mathrm{~d}, \mathrm{~J}=5.1 \mathrm{~Hz}, 1 \mathrm{H})$, 7.93-7.89 (m, $1 \mathrm{H}), 7.82-7.80$ (m, $1 \mathrm{H}), 7.55$ (dd, J = 1.5, 8.3 Hz, $1 \mathrm{H}), 6.40$ (d, J = 3.3 Hz, $1 \mathrm{H}), 4.10-4.07$ (m, $2 \mathrm{H}$ ). MS (ESI+) m/z $294(\mathrm{M}+\mathrm{H})^{+}$.

(R)-5-(7-(Trifluoromethyl)-2,3-dihydrobenzo[b][1,4]oxathiin-3-yl)-1,4-dihydropyrazine-2,3-dione (54)

Step A: 2,3-Dimethoxy-5-vinylpyrazine

5-Bromo-2,3-dimethoxypyrazine (500 mg, $2.28 \mathrm{mmol}$ ), potassium vinyl trifluoroborate (612 $\mathrm{mg}, 4.57 \mathrm{mmol})$, $\mathrm{Pd}(\mathrm{dppf}) \mathrm{Cl}_{2}$ DCM complex (186 mg, $\left.0.23 \mathrm{mmol}\right)$ and triethylamine $(0.95 \mathrm{~mL}, 6.85 \mathrm{mmol})$ were dissolved in 2propanol $(10 \mathrm{~mL})$, degassed with nitrogen and heated to reflux for $16 \mathrm{hrs}$. The reaction mixture was allowed to cool, diluted with ethyl acetate $(10 \mathrm{~mL})$ and then filtered through Celite ${ }^{\mathrm{TM}}$. The filtrate was concentrated onto silica and purified by flash column chromatography $(0-50 \%$ ethyl acetate in cyclohexane) to provide the desired product as a colourless oil (310 mg, 82\%). ${ }^{1} \mathrm{H}$ NMR (400 MHz, $\mathrm{CDCl}_{3}$ ): $\delta 7.53$ (s, $\left.1 \mathrm{H}\right), 6.66(\mathrm{dd}, \mathrm{J}=10.7,17.0 \mathrm{~Hz}, 1 \mathrm{H}), 6.15$ $(\mathrm{dd}, \mathrm{J}=1.7,17.1 \mathrm{~Hz}, 1 \mathrm{H}), 5.35$ (dd, J = 1.8, $10.7 \mathrm{~Hz}, 1 \mathrm{H}), 4.06$ (s, $3 \mathrm{H}), 4.02$ (s, $3 \mathrm{H})$.

Step B: (S)-1-(5,6-Dimethoxypyrazin-2-yl)ethane-1,2-diol

To a solution of 2,3-dimethoxy-5-vinylpyrazine $(150 \mathrm{mg}, 0.90 \mathrm{mmol})$ in a 3:1 mixture of tert-butanol $(6 \mathrm{~mL}) /$ water $(2 \mathrm{~mL})$ cooled to $0{ }^{\circ} \mathrm{C}$, was added $\mathrm{AD}$ mix alpha $(1.40 \mathrm{~g})$ and the reaction mixture was stirred for 72 hours, while being allowed to warm to room temperature. The reaction mixture was then filtered through Celite ${ }^{\mathrm{TM}}$, washing with methanol. The filtrate was concentrated directly onto silica and purified by flash column chromatography $(0-20 \%$ methanol in DCM) to provide the desired product as a colorless oil (80 mg, 44\% yield). ${ }^{1} \mathrm{H}$ NMR (400 MHz, $\left.\mathrm{CDCl}_{3}\right): \delta$ 7.73-7.71 (m, $\left.1 \mathrm{H}\right), 4.75(\mathrm{dd}, \mathrm{J}=3.7,6.8 \mathrm{~Hz}, 1 \mathrm{H}), 4.26(\mathrm{~s}, 1 \mathrm{H}), 4.00(\mathrm{~s}, 3 \mathrm{H}), 3.99(\mathrm{~s}, 3 \mathrm{H}), 3.90(\mathrm{dd}, \mathrm{J}=$ 3.7, $11.4 \mathrm{~Hz}, 1 \mathrm{H}), 3.80(\mathrm{dd}, \mathrm{J}=6.8,11.4 \mathrm{~Hz}, 1 \mathrm{H}), 3.73$ (s, $1 \mathrm{H})$.

Step C: (S)-2-((tert-Butyldimethylsilyl)oxy)-1-(5,6-dimethoxypyrazin-2-yl)ethan-1-ol

To a solution of (S)-1-(5,6-dimethoxypyrazin-2-yl)ethane-1,2-diol (90 $\mathrm{mg}, 0.45 \mathrm{mmol}$ ) and tert-butyldimethylsilyl chloride ( $81 \mathrm{mg}, 0.54 \mathrm{mmol})$ in DCM $(5 \mathrm{~mL})$ cooled to $0{ }^{\circ} \mathrm{C}$, was added imidazole $(61 \mathrm{mg}, 0.90 \mathrm{mmol})$ and the reaction mixture stirred for $4 \mathrm{hrs}$. The reaction mixture was concentrated directly onto silica and purified by flash column chromatography $(0-40 \%$ ethyl acetate in cyclohexane) to provide the desired product as a colourless oil (90 mg, 64\%). ${ }^{1} \mathrm{H}$ NMR (400 MHz, $\left.\mathrm{CDCl}_{3}\right): \delta 7.73$ (s, $\left.1 \mathrm{H}\right)$, 4.70-4.64 (m $\left.1 \mathrm{H}\right), 4.01(\mathrm{~s}, 3 \mathrm{H}), 4.00$ (s, $\left.3 \mathrm{H}\right), 3.85$ (dd, $\mathrm{J}=4.7,10.0 \mathrm{~Hz}, 1 \mathrm{H}), 3.80(\mathrm{dd}, \mathrm{J}=6.3,9.9 \mathrm{~Hz}, 1 \mathrm{H}), 3.11(\mathrm{~d}, \mathrm{~J}=5.5 \mathrm{~Hz}, 1 \mathrm{H}), 0.86(\mathrm{~s}, 9 \mathrm{H}), 0.02(\mathrm{~s}, 3 \mathrm{H}), 0.00$ (s, 3 $\mathrm{H})$. 
Step D: (R)-5-(1-((2-Bromo-4-(trifluoromethyl)phenyl)thio)-2-((tert-butyldimethylsilyl)oxy)ethyl)-2,3dimethoxypyrazine

Tributylphosphine $(0.10 \mathrm{~mL}, 0.38 \mathrm{mmol})$ was dissolved in anhydrous THF $(2.50 \mathrm{~mL})$ and cooled to $0{ }^{\circ} \mathrm{C}$. DIAD $(0.06 \mathrm{~mL}, 0.38 \mathrm{mmol})$ was added dropwise and reaction stirred at $0{ }^{\circ} \mathrm{C}$ for $15 \mathrm{~min}$. 2-bromo-4-

trifluoromethylthiophenol (98 mg, $0.38 \mathrm{mmol}$ ) and (S)-2-((tert-butyldimethylsilyl)oxy)-1-(5,6-dimethoxypyrazin-2yl)ethan-1-ol (90 mg, $0.32 \mathrm{mmol})$ were dissolved in THF $(2.50 \mathrm{~mL})$ and added slowly to the solution of DIAD and tributyl phosphine. The reaction was allowed to warm up slowly to room temperature and left stirring for $16 \mathrm{hrs}$. The reaction mixture was concentrated directly onto silica and purified by flash column chromatography $(0-20 \%$ ethyl acetate in cyclohexane), to give the title compound as a colorless oil (103 mg, 59\%). $\left.{ }^{1} \mathrm{H} \mathrm{NMR} \mathrm{(400} \mathrm{MHz,} \mathrm{CDCl}_{3}\right): \delta$ 7.77 (s, $1 \mathrm{H}), 7.70$ (s, $1 \mathrm{H}), 7.46$ (s, $2 \mathrm{H}), 4.44$ (dd, J = 5.4, $7.7 \mathrm{~Hz}, 1 \mathrm{H}), 4.19$ (dd, J = 7.7, $10.2 \mathrm{~Hz}, 1 \mathrm{H}), 4.07-4.03$ (m, 4 H), 4.00 (s, 3 H), 0.81 (s, 9 H), - -0.03 (s, 3 H), -0.06 (s, 3 H).

Step E: (R)-2-((2-Bromo-4-(trifluoromethyl)phenyl)thio)-2-(5,6-dimethoxypyrazin-2-yl)ethan-1-ol To a solution of (R)-5-(1-((2-bromo-4-(trifluoromethyl)phenyl)thio)-2-((tert-butyldimethylsilyl)oxy)ethyl)-2,3dimethoxypyrazine $(90 \mathrm{mg}, 0.19 \mathrm{mmol})$ in THF $(3 \mathrm{~mL})$ cooled to $0{ }^{\circ} \mathrm{C}$, was added tetrabutylammonium fluoride $(1$ $\mathrm{M}, 0.28 \mathrm{~mL}, 0.28 \mathrm{mmol})$ and stirred at $0{ }^{\circ} \mathrm{C}$ for 1 hour. The reaction was then diluted with ethyl acetate $(5 \mathrm{~mL})$ and washed with water $(10 \mathrm{~mL})$. The organics were then concentrated onto silica and purified by flash column chromatography ( $0-50 \%$ ethyl acetate in cyclohexane) to provide the desired product as a colorless oil (72 $\mathrm{mg}$, 89\%). ${ }^{1} \mathrm{H}$ NMR (400 MHz, $\left.\mathrm{CDCl}_{3}\right): \delta 7.82(\mathrm{~s}, 1 \mathrm{H}), 7.64(\mathrm{~s}, 1 \mathrm{H}), 7.49-7.47(\mathrm{~m}, 2 \mathrm{H}), 4.50(\mathrm{dd}, \mathrm{J}=5.4,6.4 \mathrm{~Hz}, 1 \mathrm{H})$, 4.23-4.07 (m, $2 \mathrm{H}), 4.02$ (s, $3 \mathrm{H}), 4.00$ (s, $3 \mathrm{H}), 2.92-2.77$ (m, $1 \mathrm{H})$.

Step F: (R)-2,3-Dimethoxy-5-(7-(trifluoromethyl)-2,3-dihydrobenzo[b][1,4]oxathiin-3-yl)pyrazine A suspension of (R)-2-((2-bromo-4-(trifluoromethyl)phenyl)thio)-2-(5,6-dimethoxypyrazin-2-yl)ethan-1-ol (72 mg, $0.16 \mathrm{mmol}), \mathrm{Pd}(\mathrm{II})$ acetate $(11 \mathrm{mg}, 0.05 \mathrm{mmol})$, TrixiePhos $(20 \mathrm{mg}, 0.05 \mathrm{mmol})$ and cesium carbonate $(80 \mathrm{mg}, 0.25$ $\mathrm{mmol})$ in toluene $(2 \mathrm{~mL})$ in a microwave vial was thoroughly degassed. The reaction mixture was then heated to $150{ }^{\circ} \mathrm{C}$ for two hrs under microwave irradiation. The reaction mixture was then concentrated directly onto silica and purified by flash column chromatography $(0-40 \%$ ethyl acetate in cyclohexane) to provide the desired product as an orange oil (22 mg, 38\%). ${ }^{1} \mathrm{H}$ NMR (400 MHz, $\left.\mathrm{CDCl}_{3}\right)$ : $\delta 7.72(\mathrm{~s}, 1 \mathrm{H}), 7.20(\mathrm{~d}, \mathrm{~J}=8.8 \mathrm{~Hz}, 1 \mathrm{H}), 7.12(\mathrm{~d}, \mathrm{~J}=6.8$ Hz, 2 H), 4.65 (dd, J = 2.4, 10.8 Hz, 1 H), 4.58-4.49 (m, 2 H), 4.02 (s, 3 H), 3.98 (s, 3 H).

Step G: (R)-5-(7-(Trifluoromethyl)-2,3-dihydrobenzo[b][1,4]oxathiin-3-yl)-1,4-dihydropyrazine-2,3-dione To a solution of (R)-2,3-dimethoxy-5-(7-(trifluoromethyl)-2,3-dihydrobenzo[b][1,4]oxathiin-3-yl)pyrazine (16 mg, $0.04 \mathrm{mmol})$ in 1,4-dioxane $(0.5 \mathrm{~mL})$ was added hydrochloric acid $(2 \mathrm{M}, 0.45 \mathrm{~mL})$ and the reaction mixture was heated to reflux for $2 \mathrm{hrs}$. The reaction mixture was then allowed to cool to room temperature and concentrated before purification via reverse phase chromatography to provide the desired product as a colorless solid (9 $\mathrm{mg}$, 50\%). ${ }^{1} \mathrm{H}$ NMR (400 MHz, DMSO): $\delta 11.51$ (s, $\left.1 \mathrm{H}\right), 11.22$ (d, J = 4.8 Hz, $\left.1 \mathrm{H}\right), 7.44$ (d, J = 7.8 Hz, 1 H), 7.29 (d, J $=8.6 \mathrm{~Hz}, 2 \mathrm{H}), 6.35(\mathrm{~d}, \mathrm{~J}=4.8 \mathrm{~Hz}, 1 \mathrm{H}), 4.64(\mathrm{dd}, \mathrm{J}=5.9,12.0 \mathrm{~Hz}, 1 \mathrm{H}), 4.56(\mathrm{dd}, \mathrm{J}=2.8,11.9 \mathrm{~Hz}, 1 \mathrm{H}), 4.48(\mathrm{dd}, \mathrm{J}$ $=2.4,5.8 \mathrm{~Hz}, 1 \mathrm{H}), \mathrm{MS}(\mathrm{ES}+) \mathrm{m} / \mathrm{z} 331(\mathrm{M}+\mathrm{H})^{+}$.

The following compounds were synthesized using the same procedure described for compound $\mathbf{5 4}$. 
(R)-5-(7-Fluoro-2,3-dihydrobenzo[b][1,4] oxathiin-3-yl)-1,4-dihydropyrazine-2,3-dione (56): ${ }^{1} \mathrm{H}$ NMR (400 MHz, DMSO): $\delta 11.44$ (s, $1 \mathrm{H}), 11.18$ (s, $1 \mathrm{H}), 7.20-7.15(\mathrm{~m}, 1 \mathrm{H}), 6.87-6.79(\mathrm{~m}, 2 \mathrm{H}), 6.26$ (d, J = 4.8 Hz, $1 \mathrm{H}), 4.59-4.45$ (m, $2 \mathrm{H}), 4.33(\mathrm{dd}, \mathrm{J}=2.4,5.7 \mathrm{~Hz}, 1 \mathrm{H}) . \mathrm{MS}(\mathrm{ES}+) \mathrm{m} / \mathrm{z} 281(\mathrm{M}+\mathrm{H})^{+}$.

(R)-5-(7-Chloro-2,3-dihydrobenzo[b][1,4] oxathiin-3-yl)-1,4-dihydropyrazine-2,3-dione (57): ${ }^{1} \mathrm{H}$ NMR (400 MHz, DMSO): $\delta 11.21$ (s, 2 H), 7.18 (d, J = 8.4 Hz, 1 H), 7.03-6.97 (m, 2 H), 6.27 (s, 1 H), 4.55 (dd, J = 5.8, 11.7 Hz, 1 H), $4.47(\mathrm{dd}, \mathrm{J}=2.6,11.7 \mathrm{~Hz}, 1 \mathrm{H}), 4.36(\mathrm{dd}, \mathrm{J}=2.6,5.8 \mathrm{~Hz}, 1 \mathrm{H})$. MS (ES+) m/z $297(\mathrm{M}+\mathrm{H})^{+}$.

5-(2,3-Dihydrobenzo[b][1,4]oxathiin-3-yl)-1,4-dihydropyrazine-2,3-dione (55)

Step A: 2-((tert-Butyldimethylsilyl)oxy)-1-(5,6-dimethoxypyrazin-2-yl)ethan-1-ol (rac)

5-Bromo-2,3-dimethoxypyrazine ( $2.00 \mathrm{~g}, 9.13 \mathrm{mmol})$ was dissolved in dry THF $(40 \mathrm{~mL})$ and cooled to $-78{ }^{\circ} \mathrm{C} . \mathrm{n}$ Butyl lithium (2.5 M in THF, $4.00 \mathrm{~mL}, 10.04 \mathrm{mmol}$ ) was added dropwise and the mixture stirred for $30 \mathrm{~min}$. (tertButyldimethylsilyloxy)acetaldehyde $(2.10 \mathrm{~mL}, 10.96 \mathrm{mmol})$ was dissolved in THF (2.5 mL) and added slowly. The reaction was stirred at $-78{ }^{\circ} \mathrm{C}$ for $75 \mathrm{~min}$. before warming to room temperature and quenching with saturated ammonium chloride solution $(10 \mathrm{~mL})$. The organics were separated and the aqueous extracted with ethyl acetate $(3 \mathrm{x}$ $20 \mathrm{~mL}$ ). The organics were combined and dried over sodium sulfate before concentrating and purifying by flash column chromatography ( 0 - 30\% ethyl acetate in cyclohexane) to give 2-((tert-butyldimethylsilyl)oxy)-1-(5,6dimethoxypyrazin-2-yl)ethan-1-ol as a colorless oil (1.22 g, 43\%). ${ }^{1} \mathrm{H}$ NMR (400 MHz, $\left.\mathrm{CDCl}_{3}\right): \delta 7.74(\mathrm{~s}, 1 \mathrm{H}), 4.69$ (q, J = 5.4 Hz, 1 H), $4.02(\mathrm{~s}, 3 \mathrm{H}), 4.02(\mathrm{~s}, 3 \mathrm{H}), 3.89-3.78(\mathrm{~m}, 2 \mathrm{H}), 3.12(\mathrm{~d}, \mathrm{~J}=5.5 \mathrm{~Hz}, 1 \mathrm{H}), 0.87$ (s, 9 H), 0.03 (s, $3 \mathrm{H}), 0.01(\mathrm{~s}, 3 \mathrm{H})$.

Step B: 5-(2,3-Dihydrobenzo[b][1,4]oxathiin-3-yl)-1,4-dihydropyrazine-2,3-dione

Following the same steps for compound 54 yielded the title compound as a colorless solid. ${ }^{1} \mathrm{H} \mathrm{NMR} \mathrm{(400} \mathrm{MHz,}$ DMSO): $\delta 11.19$ (s, 2 H), 7.12 (dd, J = 1.4, 7.7 Hz, 1 H), 7.05 (ddd, J = 7.7, 7.7, 1.9 Hz, 1 H), 6.94 - 6.88 (m, 2 H), 6.29 (s, 1 H), 4.53 - 4.42 (m, 2 H), 4.35 - 4.31 (m, 1 H). MS (ES+) m/z $263(\mathrm{M}+\mathrm{H})^{+}$.

(R)-5-(7-(Difluoromethyl)-2,3-dihydrobenzo[b][1,4]oxathiin-3-yl)-1,4-dihydropyrazine-2,3-dione (58)

Step A: Methyl 3-bromo-4-mercaptobenzoate

Sodium sulfide $(0.50 \mathrm{~g}, 6.44 \mathrm{mmol})$ was dissolved in DMF $(10 \mathrm{~mL})$ and stirred, methyl 3-bromo-4-fluorobenzoate $(1.00 \mathrm{~g}, 4.29 \mathrm{mmol})$ was added in three portions and reaction stirred at room temperature for $2 \mathrm{hrs}$. The reaction was diluted with water $(20 \mathrm{~mL})$ and washed with ethyl acetate $(10 \mathrm{~mL})$. The aqueous layer was then acidified to $\mathrm{pH} 2$ with $2 \mathrm{M}$ hydrochloric acid and extracted with ethyl acetate $(3 \times 10 \mathrm{~mL})$. The combined organics were dried over magnesium sulfate, concentrated in vacuo and purified by flash column chromatography $(0-100 \%$ ethyl acetate in cyclohexane) to provide the desired product. (215 mg, 20\%). ${ }^{1} \mathrm{H}$ NMR (400 MHz, $\left.\mathrm{CDCl}_{3}\right): \delta 8.16(\mathrm{~d}, \mathrm{~J}=1.9 \mathrm{~Hz}, 1$ H), 7.79 (dd, J = 1.9, 8.1 Hz, $1 \mathrm{H}), 7.37$ (d, J = 8.1 Hz, $1 \mathrm{H}), 4.21$ (s, $1 \mathrm{H}), 3.90$ (s, $3 \mathrm{H})$.

Step B: Methyl (R)-3-(5,6-dimethoxypyrazin-2-yl)-2,3-dihydrobenzo[b][1,4]oxathiine-7-carboxylate Using intermediate $(S)$-2-((tert-butyldimethylsilyl)oxy)-1-(5,6-dimethoxypyrazin-2-yl)ethan-1-ol following the same procedure as compound 54 provided the desired product. ${ }^{1} \mathrm{H}$ NMR $\left(400 \mathrm{MHz}, \mathrm{CDCl}_{3}\right): \delta 7.72(\mathrm{~s}, 1 \mathrm{H}), 7.57-7.53(\mathrm{~m}$, 2 H), 7.15 (d, J = 8.6 Hz, 1 H), 4.67-4.61 (m, 1 H), 4.56-4.51 (m, 2 H), 4.01 (s, 3 H), 3.98 (s, 3 H), 3.89 (s, 3 H). 
Step C: (R)-(3-(5,6-Dimethoxypyrazin-2-yl)-2,3-dihydrobenzo[b][1,4]oxathiin-7-yl)methanol

To an ice cooled solution of methyl (R)-3-(5,6-dimethoxypyrazin-2-yl)-2,3-dihydrobenzo[b][1,4]oxathiine-7carboxylate ( $273 \mathrm{mg}, 0.78 \mathrm{mmol})$ in THF $(8 \mathrm{~mL})$ under nitrogen was added lithium borohydride solution ( $2 \mathrm{M}$ in THF, $0.78 \mathrm{~mL}$ ) dropwise and the reaction stirred for $16 \mathrm{hrs}$. Additional lithium borohydride solution was then added $(2 \mathrm{M}, 0.78 \mathrm{~mL}$ ) and reaction stirred for further $48 \mathrm{hrs}$. The reaction was quenched by addition of water followed by extraction of the organics with ethyl acetate $(3 \times 10 \mathrm{~mL})$. The organics were combined, washed with brine $(1 \times 10$ $\mathrm{mL}$ ) and dried over magnesium sulfate before concentrating in vacuo. The crude material was then purified by flash column chromatography $(0-100 \%$ ethyl acetate in cyclohexane) to give the desired product as a off-white solid, (152 mg, 61\%). ${ }^{1} \mathrm{H}$ NMR (400 MHz, $\mathrm{CDCl}_{3}$ ): $\delta 7.74$ (s, $1 \mathrm{H}$ ), 7.09 (d, J = 8.4 Hz, $\left.1 \mathrm{H}\right), 6.91-6.89$ (m, $\left.2 \mathrm{H}\right), 4.64-$ 4.59 (m, 2 H), 4.56-4.47 (m, 2 H), 4.01 (s, 3 H), 4.00 (s, 3 H), 1.26 (t, J = 7.2 Hz, 1 H).

Step D: (R)-3-(5,6-Dimethoxypyrazin-2-yl)-2,3-dihydrobenzo[b][1,4]oxathiine-7-carbaldehyde $(R)$-(3-(5,6-dimethoxypyrazin-2-yl)-2,3-dihydrobenzo[b][1,4]oxathiin-7-yl)methanol (70 mg, $0.22 \mathrm{mmol})$ was dissolved in DCM (2 mL) under nitrogen and Dess-Martin periodinane (102 mg, $0.24 \mathrm{mmol})$ was added. The reaction was stirred at room temperature for $2 \mathrm{hrs}$. The reaction mixture was then concentrated and purified via flash column chromatography $\left(0-100 \%\right.$ ethyl acetate in cyclohexane) to give the desired product $(55 \mathrm{mg}, 79 \%) .{ }^{1} \mathrm{H}$ $\operatorname{NMR}\left(400 \mathrm{MHz}, \mathrm{CDCl}_{3}\right): \delta 9.87(\mathrm{~s}, 1 \mathrm{H}), 7.73(\mathrm{~s}, 1 \mathrm{H}), 7.41(\mathrm{dd}, \mathrm{J}=1.8,8.0 \mathrm{~Hz}, 1 \mathrm{H}), 7.37$ (d, J = 1.6 Hz, $\left.1 \mathrm{H}\right)$, 7.26-7.23 (m, 1 H), 4.69-4.63 (m, 1 H), 4.58-4.54 (m, 2 H), 4.02 (s, 3 H), 3.98 (s, 3 H).

Step E: (R)-5-(7-(Difluoromethyl)-2,3-dihydrobenzo[b][1,4]oxathiin-3-yl)-2,3-dimethoxypyrazine $(R)$-3-(5,6-Dimethoxypyrazin-2-yl)-2,3-dihydrobenzo[b][1,4]oxathiine-7-carbaldehyde (55 $\mathrm{mg}, 0.17 \mathrm{mmol}$ ) was dissolved in DCM $(2 \mathrm{~mL})$. (Diethylamino)sulfur trifluoride $(0.14 \mathrm{~mL}, 1.04 \mathrm{mmol})$ was then added and the reaction stirred for $16 \mathrm{hrs}$. The reaction mixture was then diluted with $2 \mathrm{M}$ potassium hydroxide $(15 \mathrm{~mL})$ and DCM $(10 \mathrm{~mL})$ and the organics were separated and dried through an hydrophobic frit. The organics were then concentrated and purified by flash column chromatography ( $0-100 \%$ ethyl acetate in cyclohexane) to give the desired product (32 mg, 54\%). ${ }^{1} \mathrm{H}$ NMR (400 MHz, $\left.\mathrm{CDCl}_{3}\right): \delta 7.73(\mathrm{~s}, 1 \mathrm{H}), 7.17(\mathrm{~d}, \mathrm{~J}=8.6 \mathrm{~Hz}, 1 \mathrm{H}), 7.03(\mathrm{~d}, \mathrm{~J}=5.3 \mathrm{~Hz}, 2 \mathrm{H}), 6.55(\mathrm{t}, \mathrm{J}$ $=56.6 \mathrm{~Hz}, 1 \mathrm{H}), 4.64(\mathrm{dd}, \mathrm{J}=2.3,10.9 \mathrm{~Hz}, 1 \mathrm{H}), 4.57-4.48(\mathrm{~m}, 2 \mathrm{H}), 4.01(\mathrm{~s}, 3 \mathrm{H}), 3.98(\mathrm{~s}, 3 \mathrm{H})$.

Step F: (R)-5-(7-(Difluoromethyl)-2,3-dihydrobenzo[b][1,4]oxathiin-3-yl)-1,4-dihydropyrazine-2,3-dione Hydrolysis of (R)-5-(7-(Difluoromethyl)-2,3-dihydrobenzo[b][1,4] oxathiin-3-yl)-2,3-dimethoxypyrazine with NaI and TMSCl yielded the title compound as a white solid (19 mg, $0.06 \mathrm{mmol}) .{ }^{1} \mathrm{H}$ NMR (400 MHz, DMSO): $\delta 11.46-$ 11.45 (m, 1 H), 11.18-11.18 (m, 1 H), 7.30 (d, J = 8.0 Hz, 1 H), 7.13-7.09 (m, 2 H), 6.94 (t, J = 56.1 Hz, 1 H), 6.29$6.29(\mathrm{~m}, 1 \mathrm{H}), 4.57(\mathrm{dd}, \mathrm{J}=5.8,11.7 \mathrm{~Hz}, 1 \mathrm{H}), 4.49(\mathrm{dd}, \mathrm{J}=2.7,11.8 \mathrm{~Hz}, 1 \mathrm{H}), 4.40(\mathrm{dd}, \mathrm{J}=2.5,5.8 \mathrm{~Hz}, 1 \mathrm{H}), \mathrm{MS}$ $(\mathrm{ES}+) \mathrm{m} / \mathrm{z} 313(\mathrm{M}+\mathrm{H})^{+}$.

(R)-5-(7-(Methylsulfonyl)-2,3-dihydrobenzo[b][1,4]oxathiin-3-yl)-1,4-dihydropyrazine-2,3-dione (60)

Step A: 2-Bromo-1-fluoro-4-(methylsulfonyl)benzene

A solution of 1-fluoro-4-(methylsulfonyl)benzene (1.00 g, $5.74 \mathrm{mmol})$ and N-bromosuccinimide $(1.12 \mathrm{~g}, 6.31$ mmol) in sulfuric acid $(6 \mathrm{~mL})$ was heated to $50{ }^{\circ} \mathrm{C}$, with stirring, for $16 \mathrm{hrs}$. The reaction mixture was poured over ice and the solid collected by filtration to provide the desired product as a colourless solid (1.45 g, quant.) ${ }^{1} \mathrm{H}$ NMR 
$\left(400 \mathrm{MHz}, \mathrm{CDCl}_{3}\right): \delta 8.19(\mathrm{dd}, \mathrm{J}=2.3,6.3 \mathrm{~Hz}, 1 \mathrm{H}), 7.91(\mathrm{ddd}, \mathrm{J}=2.3,4.4,8.6 \mathrm{~Hz}, 1 \mathrm{H}), 7.34-7.29(\mathrm{~m}, 1 \mathrm{H}), 3.08$ $(\mathrm{s}, 3 \mathrm{H})$.

Step B: 2-Bromo-4-(methylsulfonyl)benzenethiol

2-Bromo-1-fluoro-4-(methylsulfonyl)benzene (1.00 g, $3.95 \mathrm{mmol})$, triisopropylsilanethiol (0.85 mL, $3.95 \mathrm{mmol})$ and potassium carbonate $(0.82 \mathrm{~g}, 5.93 \mathrm{mmol})$ were dissolved in DMF $(50.00 \mathrm{~mL})$ and stirred at $50{ }^{\circ} \mathrm{C}$ for $2 \mathrm{hrs}$. The reaction mixture was then allowed to cool to room temperature and was then washed with ethyl acetate $(50 \mathrm{~mL})$. The aqueous layer was then acidified to $\mathrm{pH}<3$ with $2 \mathrm{M}$ hydrochloric acid and extracted with ethyl acetate $(3 \times 30$ $\mathrm{mL})$. The organics were combined and concentrated in vacuo, then triturated with DCM $(1 \times 10 \mathrm{~mL})$ to give the desired product as white solid (260 mg, $25 \%)$. ${ }^{1} \mathrm{H}$ NMR (400 MHz, $\left.\mathrm{CDCl}_{3}\right): \delta 8.08$ (d, J = 2.0 Hz, $\left.1 \mathrm{H}\right), 7.71$ (dd, J = 2.0, 8.3 Hz, 1 H), $7.52(\mathrm{~d}, \mathrm{~J}=8.3 \mathrm{~Hz}, 1 \mathrm{H}), 4.31(\mathrm{~s}, 1 \mathrm{H}), 3.05(\mathrm{~s}, 3 \mathrm{H}), 2.96(\mathrm{~s}, 6 \mathrm{H}), 2.88(\mathrm{~s}, 6 \mathrm{H}), 1.05(\mathrm{~s}, 1 \mathrm{H})$. Step C: (R)-5-(7-(Methylsulfonyl)-2,3-dihydrobenzo[b][1,4]oxathiin-3-yl)-1,4-dihydropyrazine-2,3-dione Using intermediate $(S)$-2-((tert-butyldimethylsilyl)oxy)-1-(5,6-dimethoxypyrazin-2-yl)ethan-1-ol (prepared following the procedure of compound 54) provided the desired product as an off white solid $(13.3 \mathrm{mg}, 45 \%) .{ }^{1} \mathrm{H}$ NMR (400 MHz, DMSO): $\delta 11.48$ (s, 1 H), 11.23-11.23 (m, 1 H), 7.45-7.43 (m, 2 H), 7.39 (dd, J = 0.6, 1.6 Hz, 1 H), $6.31(\mathrm{~s}, 1 \mathrm{H}), 4.62(\mathrm{dd}, \mathrm{J}=5.8,12.0 \mathrm{~Hz}, 1 \mathrm{H}), 4.52(\mathrm{dd}, \mathrm{J}=2.7,11.7 \mathrm{~Hz}, 1 \mathrm{H}), 4.46(\mathrm{dd}, \mathrm{J}=2.4,5.8 \mathrm{~Hz}, 1 \mathrm{H})$, $3.22(\mathrm{~s}, 3 \mathrm{H}) . \mathrm{MS}(\mathrm{ES}+) \mathrm{m} / \mathrm{z} 341(\mathrm{M}+\mathrm{H})^{+}$.

(R)-3-(5,6-Dioxo-1,4,5,6-tetrahydropyrazin-2-yl)-2,3-dihydrobenzo[b][1,4]oxathiine-7-carbonitrile (59)

Step A: 5-bromo-2-chloro-4-hydroxybenzonitrile

To a suspension of 2-chloro-4-hydroxybenzonitrile $(1.00 \mathrm{~g}, 6.51 \mathrm{mmol})$ in acetonitrile $(20 \mathrm{~mL})$ cooled to $-30{ }^{\circ} \mathrm{C}$ was added trifluoromethanesulfonic acid $(0.63 \mathrm{~mL}, 7.16 \mathrm{mmol})$ as drops and the reaction stirred for $10 \mathrm{minutes} . \mathrm{N}$ Bromosuccinimide $(1.39 \mathrm{~g}, 7.81 \mathrm{mmol})$ was added, and the reaction stirred overnight being allowed to warm to room temperature. Saturated aqueous sodium bicarbonate was added, and the organics extracted with EtOAc $(3 \times)$. The aqueous phase was acidified to $\mathrm{pH} 3$ with $1 \mathrm{M} \mathrm{HCl}(\mathrm{aq})$ and the organics were further extracted with EtOAc $(2 \times)$. The combined organics were dried over sodium sulfate, filtered and concentrated under reduced pressure. The crude material was purified by flash column chromatography (0 to 100\% EtOAc in cyclohexane) to give 5-bromo-2-chloro4-hydroxybenzonitrile as a white solid (626 mg, $41 \%$ yield). ${ }^{1} \mathrm{H} \mathrm{NMR}\left(400 \mathrm{MHz}, \mathrm{CDCl}_{3}\right) \delta 7.79(\mathrm{~s}, 1 \mathrm{H}), 7.17(\mathrm{~s}, 1 \mathrm{H})$, $6.11(\mathrm{~s}, 1 \mathrm{H})$.

Step B: $S$-(2-bromo-5-chloro-4-cyanophenyl) dimethylcarbamothioate

A solution of 5-bromo-2-chloro-4-hydroxybenzonitrile (625 mg, $2.69 \mathrm{mmol})$, dimethylthiocarbamoyl chloride (498 $\mathrm{mg}, 4.03 \mathrm{mmol})$ and 1,4-diazabicyclo[2.2.2]octane (754 mg, $6.72 \mathrm{mmol})$ in DMF (13 mL) was stirred overnight. The reaction was diluted with diethyl ether and filtered and the solid washed with diether ether $(2 \times)$. The solid was dried under vacuum yielding $O$-(2-bromo-5-chloro-4-cyanophenyl) dimethylcarbamothioate as a white solid (604 $\mathrm{mg}, 70 \%$ yield). Neat $O$-(2-bromo-5-chloro-4-cyanophenyl) dimethylcarbamothioate (600 mg, $1.88 \mathrm{mmol})$ was heated to $200{ }^{\circ} \mathrm{C}$ for 2.5 hours. The reaction was allowed to cool to room temperature and he sublimed material rinsed back into the reaction flask with DCM. The solution was concentrated under reduced pressure yielding $S$-(2bromo-5-chloro-4-cyanophenyl) dimethylcarbamothioate as a pale yellow solid (595 mg, 99\% yield). ${ }^{1} \mathrm{H}$ NMR (400 $\left.\mathrm{MHz}, \mathrm{CDCl}_{3}\right) \delta 7.92(\mathrm{~s}, 1 \mathrm{H}), 7.84(\mathrm{~s}, 1 \mathrm{H}), 3.13(\mathrm{~s}, 3 \mathrm{H}), 3.06(\mathrm{~s}, 3 \mathrm{H})$. 
Step C: 5-bromo-2-chloro-4-mercaptobenzonitrile

A mixture of $S$-(2-bromo-5-chloro-4-cyanophenyl) dimethylcarbamothioate $(595,1.86 \mathrm{mmol})$ and potassium hydroxide (313 mg, $5.59 \mathrm{mmol})$ in methanol $(2 \mathrm{~mL})$ and THF $(5 \mathrm{~mL})$ was stirred at room temperature for 90 minutes. Water was added and the organics separated. The aqueous phase was acidified to $\mathrm{pH} 2$ with $2 \mathrm{M} \mathrm{HCl}(\mathrm{aq})$ and the organics further extracted with EtOAc $(2 \times)$. The combined organics were washed with brine, dried over sodium sulfate, filtered and concentrated under reduced pressure. The crude material was purified by flash column chromatography (5 to 95\% DCM in cyclohexane yielding 5-bromo-2-chloro-4-mercaptobenzonitrile as a pale yellow solid (403 mg, 87\% yield). ${ }^{1} \mathrm{H}$ NMR (400 MHz, $\left.\mathrm{CDCl}_{3}\right) \delta 7.75(\mathrm{~s}, 1 \mathrm{H}), 7.48(\mathrm{~s}, 1 \mathrm{H}), 4.30(\mathrm{~s}, 1 \mathrm{H})$.

Step D: (R)-6-chloro-3-(5,6-dimethoxypyrazin-2-yl)-2,3-dihydrobenzo[b][1,4]oxathiine-7-carbonitrile

Following steps D-F from Example 54 yielded the title compound as a yellow solid (136 mg, 25\% over 3 steps). ${ }^{1} \mathrm{H}$ NMR (400 MHz, $\left.\mathrm{CDCl}_{3}\right)$ : ${ }^{1} \mathrm{H}$ NMR (400 MHz, CDCl3) d 7.69 (s, 1H), $7.22(\mathrm{~s}, 1 \mathrm{H}), 7.14$ (s, 1H), 4.66 - 4.60 (m, $1 \mathrm{H}), 4.55$ - 4.49 (m, 2H), 4.02 (s, 3H), 3.97 (s, 3H).

Step E: (R)-3-(5,6-Dimethoxypyrazin-2-yl)-2,3-dihydrobenzo[b][1,4]oxathiine-7-carbonitrile

To a degassed suspension of (R)-6-chloro-3-(5,6-dimethoxypyrazin-2-yl)-2,3-dihydrobenzo[b][1,4]oxathiine-7carbonitrile (100 mg, $0.29 \mathrm{mmol}$ ) and S-Phos $(47 \mathrm{mg}, 0.11 \mathrm{mmol})$ in toluene $(3 \mathrm{~mL})$ was added 4,4,5,5-tetramethyl1,3,2-dioxaborolane $(0.06 \mathrm{~mL}, 0.43 \mathrm{mmol})$ and heated to $100{ }^{\circ} \mathrm{C}$ for $16 \mathrm{hrs}$. The reaction was then allowed to cool and filtered. The solid was washed with ethyl acetate $(3 \times 10 \mathrm{~mL})$ and the organic phases combined and concentrated in vacuo and purified by flash column chromatography ( $0-100 \%$ ethyl acetate in cyclohexane) to give the desired product as an off white solid $(23 \mathrm{mg}, 26 \%) .{ }^{1} \mathrm{H}$ NMR $(400 \mathrm{MHz}, \mathrm{DMSO}): \delta 11.49(\mathrm{~s}, 1 \mathrm{H}), 11.23(\mathrm{~d}, \mathrm{~J}=$ $5.1 \mathrm{~Hz}, 1 \mathrm{H}), 7.46$ - 7.38 (m, $3 \mathrm{H}), 6.34(\mathrm{~d}, \mathrm{~J}=5.1 \mathrm{~Hz}, 1 \mathrm{H}), 4.64$ - 4.47 (m, $3 \mathrm{H})$.

Step F: (R)-3-(5,6-Dioxo-1,4,5,6-tetrahydropyrazin-2-yl)-2,3-dihydrobenzo[b][1,4]oxathiine-7-carbonitrile (R)-3-(5,6-Dimethoxypyrazin-2-yl)-2,3-dihydrobenzo[b][1,4]oxathiine-7-carbonitrile (20 mg, $0.06 \mathrm{mmol}$ ) was treated with $\mathrm{NaI}(48 \mathrm{mg}, 0.32 \mathrm{mmol})$ and $\mathrm{TMSCl}(34 \mathrm{mg}, 0.32 \mathrm{mmol})$ at $60^{\circ} \mathrm{C}$ for $45 \mathrm{~min}$. The mixture was concentrated under reduced pressure and purified by reverse phase HPLC to yield the title compound as a white solid (9 mg, 50\%). ${ }^{1} \mathrm{H}$ NMR (400 MHz, DMSO): $\delta 11.49$ (s, $\left.1 \mathrm{H}\right), 11.23$ (d, J=5.1 Hz, 1H), 7.46 - 7.38 (m, 3 H), $6.34(\mathrm{~d}, \mathrm{~J}=5.1 \mathrm{~Hz}, 1 \mathrm{H}), 4.64-4.47(\mathrm{~m}, 3 \mathrm{H}), \mathrm{MS}(\mathrm{ES}+) \mathrm{m} / \mathrm{z} 288(\mathrm{M}+\mathrm{H})^{+}$.

(R)-5-(3-Methyl-7-(trifluoromethyl)-2,3-dihydrobenzo[b][1,4]oxathiin-3-yl)-1,4-dihydropyrazine-2,3-dione (62) Step A: 2,3-Dimethoxy-5-(prop-1-en-2-yl)pyrazine

5-Bromo-2,3-dimethoxypyrazine ( $3.00 \mathrm{~g}, 13.70 \mathrm{mmol})$, isopropenylboronic acid pinacol ester (2.76 g, $16.44 \mathrm{mmol})$, $\operatorname{Pd}(0)$ tetrakistriphenylphosphine $(0.47 \mathrm{~g}, 0.41 \mathrm{mmol})$ and sodium carbonate $(4.35 \mathrm{~g}, 41.09 \mathrm{mmol})$ were dissolved in 1,4-dioxane $(30.00 \mathrm{~mL})$ and water $(20.00 \mathrm{~mL})$ and degassed. The reaction was heated to reflux for $16 \mathrm{hrs}$. The reaction mixture was allowed to cool and diluted with ethyl acetate $(30 \mathrm{~mL})$ and water $(30 \mathrm{~mL})$. The organics were separated and the aqueous layer extracted with further ethyl acetate $(2 \times 30 \mathrm{~mL})$. The combined organics were washed with water $(4 \times 20 \mathrm{~mL})$ and dried over magnesium sulfate before concentrating onto silica and purification by flash column chromatography ( 0 to $10 \%$ ethyl acetate in hexane) to give the desired compound as a colorless oil (1.89 g, 77\%). ${ }^{1} \mathrm{H}$ NMR (400 MHz, $\left.\mathrm{CDCl}_{3}\right): \delta 7.73$ (s, $\left.1 \mathrm{H}\right), 5.91(\mathrm{~d}, \mathrm{~J}=1.4 \mathrm{~Hz}, 1 \mathrm{H}), 5.16$ (dd, J = 1.6, 1.6 Hz, $1 \mathrm{H}$ ), 4.05 (s, $3 \mathrm{H}), 4.03$ (s, $3 \mathrm{H}), 2.15$ (s, $3 \mathrm{H})$. 
Step B: 2,3-Dimethoxy-5-(2-methyloxiran-2-yl)pyrazine

To a solution of 2,3-dimethoxy-5-(prop-1-en-2-yl)pyrazine (1.80 g, $9.99 \mathrm{mmol})$ in tert-butanol $(40 \mathrm{~mL})$ and water 40 $\mathrm{mL}$ ) was added $\mathrm{N}$-bromosuccinimide $(2.13 \mathrm{~g}, 11.99 \mathrm{mmol})$. The reaction was heated to $60{ }^{\circ} \mathrm{C}$ for $2 \mathrm{hrs}$ and then cooled to $0{ }^{\circ} \mathrm{C}$ before addition of $2 \mathrm{M}$ sodium hydroxide $(12.5 \mathrm{~mL})$. The reaction mixture was stirred for a further 30 min. before dilution with ethyl acetate $(40 \mathrm{~mL})$. The organics were separated and the aqueous further extracted with ethyl acetate $(3 \times 40 \mathrm{~mL})$ before combining and washing with brine $(30 \mathrm{~mL})$. The organics were then concentrated to a pink oil, which solidified on cooling, to provide the desired product $(1.84 \mathrm{~g}, 94 \%)$. ${ }^{1} \mathrm{H}$ NMR (400 MHz, CDCl3): $\delta 7.71$ (s, 1 H), 4.03 (s, 3 H), 4.01 (s, 3 H), 3.13 (d, J=5.9 Hz, 1 H), 2.97 (d, J=5.5 Hz, 1 H), 1.75 (s, 3 H). Step C: 2-((2-Bromo-4-(trifluoromethyl)phenyl)thio)-2-(5,6-dimethoxypyrazin-2-yl)propan-1-ol To a solution of 2,3-dimethoxy-5-(2-methyloxiran-2-yl)pyrazine (500 mg, $2.55 \mathrm{mmol}$ ) and 2-bromo-4(trifluormethyl)benzenethiol $(655 \mathrm{mg}, 2.55 \mathrm{mmol})$ in DCM $(20 \mathrm{~mL})$ cooled to $0{ }^{\circ} \mathrm{C}$ was added indium (III) chloride $(56 \mathrm{mg}, 0.26 \mathrm{mmol})$ and the reaction stirred for $30 \mathrm{~min}$. The reaction mixture was then washed with water $(2 \times 15$ $\mathrm{mL}$ ) and passed through a phase separator before concentrating in vacuo and purifying by flash column chromatography $(0-30 \%$ ethyl acetate in cyclohexane) to provide the desired product as a colourless oil (608 $\mathrm{mg}$, 53\%). ${ }^{1} \mathrm{H}$ NMR (400 MHz, CDCl3): $\delta 7.85$ (d, J=1.3 Hz, $\left.1 \mathrm{H}\right), 7.68$ (s, $\left.1 \mathrm{H}\right), 7.39$ (dd, J=1.4, 8.2 Hz, $\left.1 \mathrm{H}\right), 7.32$ (d, $\mathrm{J}=8.1 \mathrm{~Hz}, 1 \mathrm{H}), 4.02$ (s, $5 \mathrm{H}), 3.86$ (s, $3 \mathrm{H}), 3.15$ (dd, J=5.8, $7.8 \mathrm{~Hz}, 1 \mathrm{H}), 1.72$ (s, $3 \mathrm{H}$ ).

Step D: 2,3-Dimethoxy-5-(3-methyl-7-(trifluoromethyl)-2,3-dihydrobenzo[b][1,4]oxathiin-3-yl)pyrazine A suspension of 2-((2-bromo-4-(trifluoromethyl)phenyl)thio)-2-(5,6-dimethoxypyrazin-2-yl)propan-1-ol (600 mg, $1.32 \mathrm{mmol}), \mathrm{Pd}(\mathrm{II})$ acetate $(89 \mathrm{mg}, 0.40 \mathrm{mmol})$, TrixiePhos (158 mg, $0.40 \mathrm{mmol})$ and caesium carbonate (647 $\mathrm{mg}$, $1.99 \mathrm{mmol})$ in toluene $(6.00 \mathrm{~mL})$ in a microwave vial was thoroughly degassed. The reaction mixture was then heated to $150{ }^{\circ} \mathrm{C}$ for two hrs under microwave irradiation. The reaction mixture was then concentrated onto silica and purified by flash column chromatography ( $0-40 \%$ ethyl acetate in cyclohexane) to provide the desired product as an orange oil (440 mg, 90\%). ${ }^{1} \mathrm{H}$ NMR (400 MHz, $\left.\mathrm{CDCl}_{3}\right): \delta 7.88(\mathrm{~s}, 1 \mathrm{H}), 7.18(\mathrm{~d}, \mathrm{~J}=7.9 \mathrm{~Hz}, 1 \mathrm{H}), 7.13-7.08$ (m, 2 H), 4.76 (d, J = 11.2 Hz, 1 H), 4.23 (d, J=11.2 Hz, 1 H), 4.01 (s, 3 H), 3.99 (s, 3 H), 1.75 (s, 3 H).

Racemic 2,3-Dimethoxy-5-(3-methyl-7-(trifluoromethyl)-2,3-dihydrobenzo[b][1,4]oxathiin-3-yl)pyrazine was resolved by chiral SFC to afford single enantiomers.

2,3-Dimethoxy-5-(3-methyl-7-(trifluoromethyl)-2,3-dihydrobenzo[b][1,4]oxathiin-3-yl)pyrazine (Isomer 1), $63 \mathrm{mg}$, chiral analysis (Method 3) at $1.80 \mathrm{~min}$.

2,3-Dimethoxy-5-(3-methyl-7-(trifluoromethyl)-2,3-dihydrobenzo[b][1,4]oxathiin-3-yl)pyrazine (Isomer 2), $60 \mathrm{mg}$, chiral analysis (Method 3) at $2.30 \mathrm{~min}$.

Step E: (R)-5-(3-Methyl-7-(trifluoromethyl)-2,3-dihydrobenzo[b][1,4]oxathiin-3-yl)-1,4-dihydropyrazine-2,3-dione 2,3-Dimethoxy-5-(3-methyl-7-(trifluoromethyl)-2,3-dihydrobenzo[b][1,4]oxathiin-3-yl)pyrazine (Isomer 2) was treated with $2 \mathrm{~N} \mathrm{HCl}$ followed by reverse phase HPLC to yield the title compound as a white solid. (32 mg, 58\% ${ }^{1} \mathrm{H}$ NMR (400 MHz, DMSO): $\delta 11.42$ (s, 1 H), 11.16-11.15 (m, 1 H), 7.39-7.37 (m, 1 H), 7.26-7.23 (m, 2 H), 6.27 (d, J $=4.5 \mathrm{~Hz}, 1 \mathrm{H}), 4.88(\mathrm{~d}, \mathrm{~J}=12.2 \mathrm{~Hz}, 1 \mathrm{H}), 4.17(\mathrm{~d}, \mathrm{~J}=12.0 \mathrm{~Hz}, 1 \mathrm{H}), 1.64(\mathrm{~s}, 3 \mathrm{H}) . \mathrm{MS}(\mathrm{ES}+) \mathrm{m} / \mathrm{z} 345.1(\mathrm{M}+\mathrm{H})^{+}$

5-(3-Methyl-2,3-dihydrobenzo[b][1,4]oxathiin-3-yl)-1,4-dihydropyrazine-2,3-dione (61-rac): prepared following the same procedure as 62 without the SFC resolution. ${ }^{1} \mathrm{H}$ NMR (400 MHz, DMSO): $\delta$ 11.36-11.36 (m, $\left.1 \mathrm{H}\right), 11.14-$ 
$11.14(\mathrm{~m}, 1 \mathrm{H}), 7.10(\mathrm{dd}, \mathrm{J}=1.5,7.7 \mathrm{~Hz}, 1 \mathrm{H}), 7.07-7.02(\mathrm{~m}, 1 \mathrm{H}), 6.94-6.88(\mathrm{~m}, 2 \mathrm{H}), 6.28(\mathrm{~s}, 1 \mathrm{H}), 4.80(\mathrm{~d}, \mathrm{~J}=$ $11.9 \mathrm{~Hz}, 1 \mathrm{H}), 4.08(\mathrm{~d}, \mathrm{~J}=12.0 \mathrm{~Hz}, 1 \mathrm{H}), 1.60$ (s, $3 \mathrm{H}) . \mathrm{MS}(\mathrm{ES}+) \mathrm{m} / \mathrm{z} 277(\mathrm{M}+\mathrm{H})^{+}$.

(R)-5-(7-Chloro-3-methyl-2,3-dihydrobenzo[b][1,4] oxathiin-3-yl)-1,4-dihydropyrazine-2,3-dione (63):

Racemic 5-(7-Chloro-3-methyl-2,3-dihydrobenzo[b][1,4]oxathiin-3-yl)-1,4-dihydropyrazine-2,3-dione was prepared following the same procedure as compound $\mathbf{6 2}$.

Racemic 5-(7-Chloro-3-methyl-2,3-dihydrobenzo[b][1,4] oxathiin-3-yl)-1,4-dihydropyrazine-2,3-dione was resolved by chiral SFC to afford single enantiomers.

(R)-5-(7-Chloro-3-methyl-2,3-dihydrobenzo[b][1,4] oxathiin-3-yl)-1,4-dihydropyrazine-2,3-dione (Isomer 1) (63) :

${ }^{1} \mathrm{H}$ NMR (400 MHz, DMSO): $\delta 11.39$ (s(, $\left.1 \mathrm{H}\right), 11.16$ (s, $\left.1 \mathrm{H}\right), 7.16$ (d, J = 8.3 Hz, 1 H), 7.02-6.97 (m, 2 H), 6.26-

$6.23(\mathrm{~m}, 1 \mathrm{H}), 4.83(\mathrm{~d}, \mathrm{~J}=12.0 \mathrm{~Hz}, 1 \mathrm{H}), 4.12(\mathrm{~d}, \mathrm{~J}=12.0 \mathrm{~Hz}, 1 \mathrm{H}), 1.60(\mathrm{~s}, 3 \mathrm{H}) . \mathrm{MS}(\mathrm{ES}+) \mathrm{m} / \mathrm{z} 311(\mathrm{M}+\mathrm{H})^{+}$.

HPLC method 1, Rt 3.50 min.

(R)-3-(5,6-Dioxo-1,4,5,6-tetrahydropyrazin-2-yl)-3-methyl-2,3-dihydrobenzo[b][1,4]oxathiine-7-carbonitrile (64)

Step A: 3-Bromo-4-mercaptobenzonitrile

3-Bromo-4-fluorobenzonitrile $(0.75 \mathrm{~g}, 3.75 \mathrm{mmol})$ triisopropylsilanethiol $(0.81 \mathrm{~mL}, 3.75 \mathrm{mmol})$ and potassium carbonate $(0.77 \mathrm{~g}, 5.62 \mathrm{mmol})$ were dissolved in DMF $(30 \mathrm{~mL})$ and stirred at $50{ }^{\circ} \mathrm{C}$ for $3 \mathrm{hrs}$. The reaction mixture was then allowed to cool to room temperature and was then washed with ethyl acetate $(30 \mathrm{~mL})$. The aqueous layer was then acidified to $\mathrm{pH}<3$ with $2 \mathrm{M}$ hydrochloric acid and extracted with ethyl acetate $(3 \times 20 \mathrm{~mL})$. The organics were combined and concentrated in vacuo, then triturated with DCM $(10 \mathrm{~mL})$ to give the desired product as a yellow solid (528 mg, 66\%). ${ }^{1} \mathrm{H}$ NMR (400 MHz, CDCl $)$ : $\delta 7.80$ (t, J = 1.0 Hz, $1 \mathrm{H}$ ), 7.44-7.43 (m, $2 \mathrm{H}$ ), 4.27 (s, $1 \mathrm{H}$ ).

Step B: 3-(5,6-Dimethoxypyrazin-2-yl)-3-methyl-2,3-dihydrobenzo[b][1,4]oxathiine-7-carbonitrile

The title compound was prepared following the same procedure as compound $\mathbf{6 2}$ as an orange oil $(172 \mathrm{mg}, 37 \%$ over two steps). ${ }^{1} \mathrm{H}$ NMR (400 MHz, $\left.\mathrm{CDCl}_{3}\right) \delta 7.85$ (s, $\left.1 \mathrm{H}\right), 7.16-7.14(\mathrm{~m}, 2 \mathrm{H}), 7.10$ (d, J = 1.5 Hz, $\left.1 \mathrm{H}\right), 4.75$ (d, $\mathrm{J}=11.2 \mathrm{~Hz}, 1 \mathrm{H}), 4.23(\mathrm{~d}, \mathrm{~J}=11.2 \mathrm{~Hz}, 1 \mathrm{H}), 4.01$ (s, $3 \mathrm{H}), 4.00$ (s, $3 \mathrm{H}), 1.76$ (s, $3 \mathrm{H})$.

Step C: 3-(5,6-Dimethoxypyrazin-2-yl)-3-methyl-2,3-dihydrobenzo[b][1,4]oxathiine-7-carbonitrile (Isomers 1 and 2)

Racemic 3-(5,6-dimethoxypyrazin-2-yl)-3-methyl-2,3-dihydrobenzo[b][1,4]oxathiine-7-carbonitrile was resolved by chiral SFC to afford single enantiomers.

3-(5,6-dimethoxypyrazin-2-yl)-3-methyl-2,3-dihydrobenzo[b][1,4]oxathiine-7-carbonitrile (Isomer 1), white solid, (38 mg, $0.21 \mathrm{mmol}$ ), chiral analysis (Method 2) at $6.00 \mathrm{~min}$.

3-(5,6-dimethoxypyrazin-2-yl)-3-methyl-2,3-dihydrobenzo[b][1,4]oxathiine-7-carbonitrile (Isomer 2), white solid, (39 mg, $0.21 \mathrm{mmol}$ ), chiral analysis (Method 2) at $5.00 \mathrm{~min}$.

Step D: (R)-3-(5,6-Dioxo-1,4,5,6-tetrahydropyrazin-2-yl)-3-methyl-2,3-dihydrobenzo[b][1,4]oxathiine-7carbonitrile

Treating 3-(5,6-dimethoxypyrazin-2-yl)-3-methyl-2,3-dihydrobenzo[b][1,4]oxathiine-7-carbonitrile (Isomer 1) with $2 \mathrm{~N} \mathrm{HCl}$ provided the product as a colorless solid (3 mg, $0.01 \mathrm{mmol}, 6 \%$ ). ${ }^{1} \mathrm{H}$ NMR (400 MHz, DMSO): $\delta 11.38$ (s, 
$1 \mathrm{H}), 11.16$ (s, $1 \mathrm{H}), 7.16$ (d, J = 8.4 Hz, $1 \mathrm{H}), 7.02-6.97$ (m, $2 \mathrm{H}), 6.27-6.25(\mathrm{~m}, 1 \mathrm{H}), 4.83(\mathrm{~d}, \mathrm{~J}=12.2 \mathrm{~Hz}, 1 \mathrm{H})$, $4.12(\mathrm{~d}, \mathrm{~J}=12.0 \mathrm{~Hz}, 1 \mathrm{H}), 1.60$ (s, $3 \mathrm{H})$. MS (ES+) m/z $295(\mathrm{M}+\mathrm{H})^{+}$.

(R)-5-(3-Methyl-7-(methylsulfonyl)-2,3-dihydrobenzo[b][1,4]oxathiin-3-yl)-1,4-dihydropyrazine-2,3-dione (65) Racemic 5-(3-Methyl-7-(methylsulfonyl)-2,3-dihydrobenzo[b][1,4]oxathiin-3-yl)-1,4-dihydropyrazine-2,3-dione was prepared following the same procedure as 62. ${ }^{1} \mathrm{H}$ NMR (400 MHz, DMSO): $\delta 11.41(\mathrm{~s}, 1 \mathrm{H}), 11.18(\mathrm{~s}, 1 \mathrm{H})$, 7.43-7.38 (m, 3 H), 6.30-6.28 (m, 1 H), 4.92-4.87 (m, 1 H), 4.21-4.16 (m, 1 H), 3.21 (s, 3 H), 1.64 (s, 3 H). MS $(\mathrm{ES}+) \mathrm{m} / \mathrm{z} 355.0(\mathrm{M}+\mathrm{H})^{+}$.

Racemic 5-(3-Methyl-7-(methylsulfonyl)-2,3-dihydrobenzo[b][1,4]oxathiin-3-yl)-1,4-dihydropyrazine-2,3-dione was resolved by chiral SFC to afford single enantiomers.

(R)-5-(3-Methyl-7-(methylsulfonyl)-2,3-dihydrobenzo[b][1,4]oxathiin-3-yl)-1,4-dihydropyrazine-2,3-dione (Isomer 1) (65): ${ }^{1} \mathrm{H}$ NMR (400 MHz, DMSO): $\delta 11.06$ (s, 2 H), 7.47 (s, 2 H), 7.43 (s, 1 H), 6.33 (s, 1 H), 4.93 (d, J = 12.1 $\mathrm{Hz}, 1 \mathrm{H}), 4.22(\mathrm{~d}, \mathrm{~J}=12.1 \mathrm{~Hz}, 1 \mathrm{H}), 3.25(\mathrm{~s}, 3 \mathrm{H}), 1.68(\mathrm{~s}, 3 \mathrm{H}), \mathrm{MS}(\mathrm{ES}+) \mathrm{m} / \mathrm{z} 355(\mathrm{M}+\mathrm{H})^{+}$. Chiral analysis (Method 1) at $3.26 \mathrm{~min}$.

(R)-5-(7-(((3-Fluorobenzyl)oxy)methyl)-2,3-dihydrobenzo[b][1,4]oxathiin-3-yl)-1,4-dihydropyrazine-2,3-dione (66) Step A: (R)-5-(7-(((3-Fluorobenzyl)oxy)methyl)-2,3-dihydrobenzo[b][1,4]oxathiin-3-yl)-2,3-dimethoxypyrazine $(R)$-(3-(5,6-dimethoxypyrazin-2-yl)-2,3-dihydrobenzo[b][1,4]oxathiin-7-yl)methanol (prepared following steps A-C of compound 58) (125 mg, $0.39 \mathrm{mmol})$ was dissolved in THF ( $3 \mathrm{~mL})$ and cooled to $0{ }^{\circ} \mathrm{C}$. Sodium hydride $(60 \%$ in mineral oil, $62 \mathrm{mg}, 1.56 \mathrm{mmol}$ ) was then added and the solution stirred at $0{ }^{\circ} \mathrm{C}$ for $15 \mathrm{~min}$. before addition of 3 fluorobenzyl bromide $(0.06 \mathrm{~mL}, 0.47 \mathrm{mmol})$. The reaction was stirred at $0{ }^{\circ} \mathrm{C}$ for $3 \mathrm{hrs}$ before allowing to rise to room temperature and quenching with dropwise addition of water $(3 \mathrm{~mL})$. The mixture was extracted with ethyl acetate $(3 \times 10 \mathrm{~mL})$, combined and washed with brine $(1 \times 10 \mathrm{~mL})$ and dried over magnesium sulfate before concentrating in vacuo and purifying via flash column chromatography ( 0 - 30\% ethyl acetate in cyclohexane) to give the desired product as a yellow oil, (74 mg, 55\%). ${ }^{1} \mathrm{H}$ NMR (400 MHz, $\left.\mathrm{CDCl}_{3}\right): \delta 7.74(\mathrm{~s}, 1 \mathrm{H}), 7.34-7.27$ (m, 1 H), 7.13-7.06 (m, 3 H), 7.01-6.94 (m, 1 H), 6.91-6.88 (m, 2 H), 4.62 (dd, J = 2.5, 10.9 Hz, 1 H), 4.57-4.47 (m, 6 H), 4.01 (s, $3 \mathrm{H}), 3.99$ (s, $3 \mathrm{H})$.

Step B: (R)-5-(7-(((3-Fluorobenzyl)oxy)methyl)-2,3-dihydrobenzo[b][1,4]oxathiin-3-yl)-1,4-dihydropyrazine-2,3dione

(R)-5-(7-(((3-Fluorobenzyl)oxy)methyl)-2,3-dihydrobenzo[b][1,4] oxathiin-3-yl)-2,3-dimethoxypyrazine (60 mg, $0.14 \mathrm{mmol})$ was treated with $\mathrm{NaI}(76 \mathrm{mg}, 0.7 \mathrm{mmol})$ and $\mathrm{TMSCl}(105 \mathrm{mg}, 0.7 \mathrm{mmol})$ at $60{ }^{\circ} \mathrm{C}$ for $45 \mathrm{~min}$. The mixture was concentrated under reduced pressure and purified by reverse phase HPLC to yield the title compound as a white solid (18 mg, 32\%). ${ }^{1} \mathrm{H}$ NMR (400 MHz, DMSO): $\delta$ 11.35-11.18 (m, $2 \mathrm{H}$ ), 7.45-7.39 (m, $\left.1 \mathrm{H}\right), 7.22-7.10$ (m, 4 H), 6.95-6.89 (m, 2 H), 6.28 (s, 1 H), 4.55-4.45 (m, 6 H), 4.33 (dd, J = 2.3, 5.9 Hz, 1 H), MS (ES+) m/z 401 $(\mathrm{M}+\mathrm{H})^{+}$.

1-Hydroxy-5-phenethylpyrimidine-2,4(1H,3H)-dione (13)

Step A: 1-(benzyloxy)pyrimidine-2,4(1H,3H)-dione 
To a solution of benzyloxy urea $(3.00 \mathrm{~g}, 18.05 \mathrm{mmol})$ and methyl 3,3-demothxy propionate $(2.60 \mathrm{ml}, 18.05 \mathrm{mmol})$ in DMSO $(15 \mathrm{~mL})$ was added sodium hydride $60 \%(0.65 \mathrm{~g}, 18.05 \mathrm{mmol})$. The reaction was heated to $65^{\circ} \mathrm{C}$ for 2 hours before allowing to cool and neutralising with $2 \mathrm{M} \mathrm{HCl}$, the resultant precipitate was collected via filtration and further drying to afford 1-(benzyloxy)pyrimidine-2,4(1H,3H)-dione $(1.50 \mathrm{~g}, 38 \%)$.

${ }^{1} \mathrm{H}$ NMR (400 MHz, DMSO) $\delta 11.55$ (s, 1H), 7.85 (d, J=8.2 Hz, 1H), 7.57 - 7.47 (m, 5H), 5.47 (d, J=8.6 Hz, 1H), $5.17(\mathrm{~s}, 2 \mathrm{H})$.

Step B: 3-Benzyl-1-(benzyloxy)pyrimidine-2,4(1H,3H)-dione

To a solution of 1-(benzyloxy)pyrimidine-2,4(1H,3H)-dione $(2.00 \mathrm{~g}, 9.17 \mathrm{mmol})$ and potassium carbonate $(1.52 \mathrm{~g}$, $11.00 \mathrm{mmol})$ in DMF $(20 \mathrm{~mL})$ was added benzyl bromide $(1.1 \mathrm{~mL}, 9.17 \mathrm{mmol})$ and the reaction heated to $80^{\circ}$ for 1 hour. The reaction was then allowed to cool to room temperature, followed by addition of water $(40 \mathrm{~mL})$ resulting in precipitation of a colourless solid. The solid was isolated via filtration to afford 3-benzyl-1-(benzyloxy)pyrimidine2,4(1H,3H)-dione $(2.51 \mathrm{~g}, 89 \%)$ as a colourless solid.

${ }^{1} \mathrm{H}$ NMR $\left(400 \mathrm{MHz}, \mathrm{CDCl}_{3}\right) \delta 7.49(\mathrm{~d}, \mathrm{~J}=6.7 \mathrm{~Hz}, 2 \mathrm{H}), 7.42-7.26(\mathrm{~m}, 8 \mathrm{H}), 6.99(\mathrm{~d}, \mathrm{~J}=8.4 \mathrm{~Hz}, 1 \mathrm{H}), 5.15(\mathrm{~s}, 2 \mathrm{H})$, $5.12(\mathrm{~s}, 2 \mathrm{H})$.

Step C: 3-Benzyl-1-(benzyloxy)-2,4-dioxo-1,2,3,4-tetrahydropyrimidine-5-carbaldehyde

To a solution of 3-benzyl-1-(benzyloxy)pyrimidine-2,4(1H,3H)-dione (1.00 g, $3.24 \mathrm{mmol})$ in TFA (10.00 mL) was added Hexamethylenetetramine $(0.50 \mathrm{~g}, 3.57 \mathrm{mmol})$ and the reaction mixture heated to reflux for 6 hours. The reaction was then allowed to cool and poured of $2 \mathrm{~N} \mathrm{HCl}$ and stirred for a further 30 mins. The organics were then extracted with DCM $(3 \times 15 \mathrm{~mL})$ before combining and washing with $2 \mathrm{~N} \mathrm{HCl}(10 \mathrm{~mL})$ and drying over $\mathrm{MgSO}_{4}$, concentrated in vacuo and purified by flash column chromatography (10-60\% ethyl acetate in cyclohexane) to afford 3-benzyl-1-(benzyloxy)-2,4-dioxo-1,2,3,4-tetrahydropyrimidine-5-carbaldehyde ( $0.37 \mathrm{~g}, 36 \%)$ as a colorless solid.

${ }^{1} \mathrm{H}$ NMR (400 MHz, CDCl3) $\delta 9.90(\mathrm{~s}, 1 \mathrm{H}), 7.86(\mathrm{~s}, 1 \mathrm{H}), 7.49(\mathrm{~d}, \mathrm{~J}=6.6 \mathrm{~Hz}, 2 \mathrm{H}), 7.42$ - $7.31(\mathrm{~m}, 8 \mathrm{H}), 5.22(\mathrm{~s}, 2 \mathrm{H})$, $5.16(\mathrm{~s}, 2 \mathrm{H})$.

Step D: (E)-3-Benzyl-1-(benzyloxy)-5-styrylpyrimidine-2,4(1H,3H)-dione

To a solution of benzyltriphenylphosphonium bromide ( $322 \mathrm{mg}, 0.74 \mathrm{mmol})$ in THF $(5 \mathrm{~mL})$ was added sodium hydride $60 \%$ (45 mg, $1.11 \mathrm{mmol}$ ) and the solution stirred for 20 minutes. A solution of 3-benzyl-1-(benzyloxy)-2,4dioxo-1,2,3,4-tetrahydropyrimidine-5-carbaldehyde (250 mg, $0.74 \mathrm{mmol})$ in THF ( $5 \mathrm{~mL}$ ) was then added the reaction refluxed. The reaction was cooled, and the precipitate removed via filtration. The filtrate was concentrated in vacuo and purified by flash column chromatography (10 - 60\% ethyl acetate in cyclohexane) to afford (E)-3benzyl-1-(benzyloxy)-5-styrylpyrimidine-2,4(1H,3H)-dione $(55 \mathrm{mg}, 17 \%)$ as a pale yellow solid. ${ }^{1} \mathrm{H}$ NMR (400 MHz, CDCl3) $\delta 7.50$ (d, J=7.2 Hz, 2H), 7.36 - 7.18 (m, 15H), 7.04 (s, 1H), 6.65 (d, J=13.3 Hz, 1H), $6.32(\mathrm{~d}, \mathrm{~J}=11.7 \mathrm{~Hz}, 1 \mathrm{H}), 5.16(\mathrm{~s}, 2 \mathrm{H}), 4.92(\mathrm{~s}, 2 \mathrm{H})$.

Step E: 1-Hydroxy-5-phenethylpyrimidine-2,4(1H,3H)-dione (13)

(E)-3-Benzyl-1-(benzyloxy)-5-styrylpyrimidine-2,4(1H,3H)-dione was dissolved in methanol (conc. < $0.05 \mathrm{M}$ ), and Hydrogenated over Pd/C cat cart using a H-Cube (flow $1 \mathrm{mLmin}^{-1}$ ). The resulting solution was then concentrated 
under reduced pressure and suspended in m-Xylene and transferred to a pressure tube. Boron tribromide (1M DCM, $0.5 \mathrm{~mL}$ ) was then added and the reaction heated to reflux for 1 hour. The reaction mixture was allowed to cool before careful quenching with methanol and concentrating in vacuo and purified by preparative HPLC to afford the title compound (5.6 mg, 21\%)

${ }^{1} \mathrm{H}$ NMR (400 MHz, DMSO) $\delta 9.23$ - $9.23(\mathrm{~m}, 2 \mathrm{H}), 7.59(\mathrm{~s}, 1 \mathrm{H}), 7.30$ - $7.25(\mathrm{~m}, 2 \mathrm{H}), 7.20$ - $7.15(\mathrm{~m}, 3 \mathrm{H})$. MS (ES+) m/z $233.1(\mathrm{M}+\mathrm{H})^{+}$.

5-(4-Chlorophenethyl)-1-hydroxypyrimidine-2,4(1H,3H)-dione (16)

Step A: (E)-3-Benzyl-1-(benzyloxy)-5-(4-chlorostyryl)pyrimidine-2,4(1H,3H)-dione

To a solution of (4-chlorobenzyl)triphenylphosphonium bromide $(287 \mathrm{mg}, 0.60 \mathrm{mmol})$ in THF $(5 \mathrm{~mL})$ was added sodium hydride $60 \%$ (26 mg, $0.89 \mathrm{mmol}$ ) and the solution stirred for 20 minutes. A solution of 3-benzyl-1(benzyloxy)-2,4-dioxo-1,2,3,4-tetrahydropyrimidine-5-carbaldehyde ( $250 \mathrm{mg}, 0.60 \mathrm{mmol}$ ) in THF (5 mL) was then added the reaction refluxed. The reaction was cooled and precipitate removed via filtration. The filtrate was concentrated in vacuo and purified by flash column chromatography (10 - 60\% ethyl acetate in cyclohexane) to afford (E)-3-benzyl-1-(benzyloxy)-5-(4-chlorostyryl)pyrimidine-2,4(1H,3H)-dione (143 mg, 54\%) as a pale yellow solid.

${ }^{1} \mathrm{H}$ NMR (400 MHz, CDCl3 $\delta 7.50$ (dd, J=1.3, 8.0 Hz, 2H), 7.38 - 7.29 (m, 7H), 7.26 - 7.24 (m, 5H), 7.04 (d, J=0.4 $\mathrm{Hz}, 1 \mathrm{H}), 6.56(\mathrm{~d}, \mathrm{~J}=12.4 \mathrm{~Hz}, 1 \mathrm{H}), 6.34(\mathrm{dd}, \mathrm{J}=0.8,12.2 \mathrm{~Hz}, 1 \mathrm{H}), 5.16(\mathrm{~s}, 2 \mathrm{H}), 4.97$ (s, 2H).

Step B: 5-(4-Chlorophenethyl)-1-hydroxypyrimidine-2,4(1H,3H)-dione (E)-3-Benzyl-1-(benzyloxy)-5-(4-chlorostyryl)pyrimidine-2,4(1H,3H)-dione (143 mg, $0.31 \mathrm{mmol}$ ) was dissolved in methanol (conc. $<0.05 \mathrm{M}$ ), and Hydrogenated over Pd/C cat cart using a H-Cube (flow $1 \mathrm{mLmin}-1$ ). The resulting solution was then concentrated under reduced pressure and suspended in m-xylene and transferred to a pressure tube. Boron tribromide (1M DCM, $0.5 \mathrm{~mL}$ ) was then added and the reaction heated to reflux for 1 hour. The reaction mixture was allowed to cool before careful quenching with methanol and concentrating in vacuo and purifying by preparative HPLC to afford the title compound (11 mg, 6\%) as an off-white amorphous solid.

${ }^{1} \mathrm{H}$ NMR (400 MHz, DMSO) $\delta, 7.62$ (s, 1H), 7.34 (d, J=8.7 Hz, 2H), 7.22 (d, J=8.5 Hz, 2H), 2.75 (t, J=8.0 Hz, 2H), $2.46(\mathrm{t}, \mathrm{J}=8.3 \mathrm{~Hz}, 2 \mathrm{H})$. MS (ES+) m/z $267.2(\mathrm{M}+\mathrm{H})^{+}$.

\section{ASSOCIATED CONTENT}

\section{Supporting Information}

1) Macro-PK protocol

2) Computation of tautomer distributions

3) hDAO co-crystallization conditions with data collection and refinement statistics with $\mathbf{1 2}$ and $\mathbf{5 9}$

4) H-NMR and LC-MS spectra of key compounds 37 and 42.

5) H-NMR of other final compounds

6) All compounds with prospective FEP+ hDAO potency and experimental biochemical potency

7) Molecular formula strings 


\title{
Access Codes
}

Coordinates and structure factors for hDAO complexes with compounds $\mathbf{1 2}$ and $\mathbf{5 9}$ will be submitted to the PDB.

\section{AUTHOR INFORMATION}

\author{
Corresponding Author
}

*H.T. Email: wayne.tang@schrodinger.com

\section{ACKNOWLEDGEMENTS}

The authors thank Drs. Edcon Chang, Holger Monenshein, and Jordi Serrats at Takeda San Diego for insightful discussions on the project. We are also grateful to Takeda for structural support (by Robert Skene) and sharing of tool compounds 17 and PGM019260.

\section{ABBREVIATIONS USED}

DAO D-amino Acid Oxidase; FAD flavin adenine dinucleotide; NMDA N-methyl D-aspartate; FEP free energy perturbation; Papp apparent permeability; ER efflux ratio; QM quantum mechanics; SAR structure-activity relationship; HRP horseradish peroxidase; PK pharmacokinetics; PD pharmacodynamics; MPO multiparameter optimization; CNS MPO central nervous system multiparameter optimization; LE ligand efficiency; LLE lipophilic ligand efficiency; MDR1 multidrug resistance protein 1; MDCK Madin-Darby canine kidney; CSF cerebrospinal fluid

\section{REFERENCES}

\footnotetext{
1 Verrall, L.; Burnet, P. W.; Betts, J. F.; Harrison, P. J. The neurobiology of D-amino acid oxidase and its involvement in schizophrenia. Mol. Psychiatry, 2012, 15(2), 122-137.

2 Hashimoto, K.; Fukushima, T.; Shimizu, E.; Kamatsu, N.; Watanabe, H.; Shinoda, N.; Nakazato, M.; Kumakiri, C.; Okada, S.; Hasegawa, H.; Imai, K.; lyo, M. Decreased Serum Levels of D-Serine in Patients With Schizophrenia: Evidence in Support of the N-Methyl-D-Aspartate Receptor Hypofunction Hypothesis of Schizophrenia. Arch Gen Psychiatry. 2003, 60(6): 572-576.

3 (a) Tsai, G.; Yang, P.; Chung, L. C.; Lange, N.; Coyle, J. T. D-serine added to antipsychotics for the treatment of schizophrenia. Biol. Psychiatry, 1998; 44: 1081-9. (b) Heresco-Levy, U.; Javitt, D. C.; Ebstein, R.; Vass, A.; Lichtenberg, P.; Bar, G.; Catinari, S.; Ermilov, M. D-serine efficacy as add-on pharmacotherapy to risperidone and olanzapine for treatment-refractory schizophrenia. Biol. Psychiatry 2005; 57: 577-85.

${ }^{4}$ Frisell, W. R.; Lowe, H. J.; Hellerman, L. Flavoenzyme catalysis. Substrate-competitive inhibition of D-amino acid oxidase. J. Biol. Chem.1956, 223, 75-83.

5 The subject was reviewed in: Sacchia, S.; Rosini, E.; Pollegionia, L.; and Molla, G. D-Amino Acid Oxidase Inhibitors as a Novel Class of Drugs for Schizophrenia Therapy, Current Pharmaceutical Design, 2013, 19, $2499-2511$.

6 (a) Adage, T.; Trillat, A. C.; Quattropani, A.; Perrin, D.; Cavarec, L.; Shaw, J.; Guerassimenko, O.; Giachetti, C.; Greco, B.; Chumakov, I.; Halazy, S.; Roach, A.; Zaratin, P. In vitro and in vivo pharmacological profile of AS057278, a selective D-amino acid oxidase inhibitor with potential anti-psychotic properties. Eur. Neuropsychopharmacol 2008, 18, 200-14. (b) Ferraris, D.; Duvall, B.; Ko, Y. S.; Thomas, A. G.; Rojas, C.; Majer, P.; Hashimoto, K.; Tsukamoto, T. Synthesis and biological evaluation of D-amino acid oxidase inhibitors. J. Med. Chem. 2008, 51, 3357-9. (c) Sparey,
} 
T.; Abeywickrema, P.; Almond, S.; Brandon, N.; Byrne, N.; Campbell, A.; Hutson, P. H.; Jacobson, M.; Jones, B.; Munshi, S.; Pascarella, D.; Pike, A.; Prasad, S. G.; Sachs, N.; Sakatis, M.; Sardana, V.; Venkatraman, S.; Young, M. B. The discovery of fused pyrrole carboxylic acids as novel, potent D-amino acid oxidase (DAO) inhibitors. Bioorg. Med. Chem. Lett. 2008, 18, 3386-91. (d) Smith, S. M.; Uslaner, J. M.; Yao, L.; Mullins, C. M.; Surles, N. O.; Huszar, S. L.; McNaughton, C. H.; Pascarella, D. M.; Kandebo, M.; Hinchliffe, R. M.; Sparey, T.; Brandon, N. J.; Jones, B.; Venkatraman, S.; Young, M. B.; Sachs, N.; Jacobson, M. A.; Hutson, P. H. The behavioural and neurochemical effects of a novel D-amino acid oxidase inhibitor compound 8 [4H-thieno [3,2-b]pyrrole-5-carboxylic acid] and Dserine. J. Pharmacol. Exp. Ther. 2009, 328, 921-30. (e) Duplantier, A. J.; Becker, S.L.; Bohanon, M. J.; Borzilleri, K. A.; Chrunyk, B. A.; Downs, J. T.; Hu, L-Y.; El-Kattan, A.; James, L. C.; Liu, S.; Lu, J.; Maklad, N.; Mansour, M. N.; Mente, S.; Piotrowski, M. A.; Sakya, S. M.; Sheehan, S.; Steyn, S. J.; Strick, C. A.; Williams, V. A.; Zhang, L. Discovery, SAR, and pharmacokinetics of a novel 3-hydroxyquinolin-2(1H)-one series of potent D-amino acid oxidase (DAAO) inhibitors. J. Med. Chem. 2009, 52, 3576-85.

${ }^{7}$ Hondo, T.; Warizaya, M.; Niimi, T.; Namatame, I.; Yamaguchi, T.; Nakanishi, K.; Hamajima, T.; Harada, K.; Sakashita, H.; Matsumoto, Y.; Orita, M. and Takeuchi, M. Journal of Medicinal Chemistry, 2013, 56(9), 3582-3592.

${ }^{8}$ Raje, M.; Hin, N.; Duvall, B.; Ferraris, D. V.; Berry, J. F.; Thomas, A. G.; Alt, J.; Rojas, C.; Slusher, B. S.;

Tsukamoto, T. Synthesis of kojic acid derivatives as secondary binding site probes of d-amino acid oxidase. Bioorg. Med. Chem. Lett. 2013, 23, 3910-3913.

9 Terry-Lorenzo, R. T.; Chun, L. E.; Brown, S. P.; Heffernan, M.; Fang, Q. K.; Orsini, M. A.; Pollegioni, L.; Hardy, L. W.; Spear, K. L. and Large, T. H. Novel human D-amino acid oxidase inhibitors stabilize an active-site lid-open conformation, Biosci. Rep. 2014, 34, art:e00133 / doi 10.1042/BSR20140071

${ }^{10} \mathrm{https}: / /$ clinicaltrials.gov/ct2/show/NCT03094429?term=NaBen\&draw=2\&rank=3

11 https://clinicaltrials.gov/ct2/show/NCT03382639?term=TAK-831\&draw=2\&rank=6

12 https://www.takeda.com/newsroom/newsreleases/2020/neurocrine-biosciences-and-takeda-announcecollaboration-to-develop-and-commercialize--potential-therapies-for-psychiatric-disorders/

${ }^{13} \mathrm{https}$ ://www.prnewswire.com/news-releases/neurocrine-biosciences-announces-top-line-results-from-phase-iiinteract-study-evaluating-luvadaxistat-nbi-1065844-for-the-treatment-of-negative-symptoms-and-cognitiveimpairment-associated-with-schizophrenia-cias-301238086.html

${ }^{14}$ Hopkins, S. C.; Campbell, U. C.; Heffernan, M. L. R.; Spear, K. L.; Jeggo, R. D.; Spanswick, D. C.; Varney, M. A.; Large, T. H. Effects of d-amino acid oxidase inhibition on memory performance and long-term potentiation in vivo Pharmacol. Res. \& Perspect. 2013, 1(1), e00007/1-e00007/9.

${ }^{15}$ The FEP+ model development will be submitted simultaneously. The reference will be added when it is published.

${ }^{16}$ Compound 14 was previously disclosed in W01993008197A1 as an antagonist at the glycine-binding site on the NMDA receptor complex.

17 To track performance of the hDAO FEP+ model, the predicted hDAO IC 50 's are also included in the table. Predictions with over 1 log difference from the experimental value are colored in yellow, and those with 2 logs difference are colored in red.

${ }^{18}$ Howley, E.; Bestwick, M.; Fradley, R.; Harrison, H.; Leveridge, M.; Okada, K.; Fieldhouse, C.; Farnaby, W.; Canning, H.; Sykes, A. P.; Merchant, K.; Hazel, K.; Kerr, C.; Kinsella, N.; Walsh, L.; Livermore, D. G.; Hoffman, I.; Ellery, J.; Mitchell, P.; Patel, T.; Carlton, M.; Barnes, M.; Miller, D. J. Assessment of the Target Engagement and DSerine Biomarker Profiles of the D-Amino Acid Oxidase Inhibitors Sodium Benzoate and PGM030756. Neurochem. Res. 2017, 42(11), 3279-3288.

${ }^{19}$ The PK data of 17 is consistent with that disclosed in Neurochemical Research, 2017, 42(11), 3279-3288.

20 The pKa value was prospectively predicted to be 9.5 by the Schrödinger Macro-pKa protocol based on quantum mechanics energy calculations. See supplementary information for detailed description of the protocol and validation data. The protocol has been used on the program to predict pKa of design ideas.

${ }^{21}$ Compound 11 has a pKa of 6.4 as predicted by the Schrödinger Macro-pKa protocol.

22 No synthesis was attempted on $\mathbf{3 3}$ based on predicted FEP+ potency.

23 The compound could not be resolved due to technical difficulties, so it was tested as a racemate.

${ }^{24} \mathrm{FEP}+$ performance was sufficient to drive synthesis decisions. The mean unsigned error (MUE) of all predictions to date is $0.7 \mathrm{log}$. 